University of South Florida

DIGITAL COMMONS

@ UNIVERSITY OF SOUTH FLORIDA
Digital Commons @ University of

South Florida

$12-1-2018$

\title{
Transit and Livability: Results from the National Community Livability Survey
}

CUTR

Follow this and additional works at: https://digitalcommons.usf.edu/cutr_nctr

\section{Scholar Commons Citation}

CUTR, "Transit and Livability: Results from the National Community Livability Survey" (2018). Research Reports. 39.

https://digitalcommons.usf.edu/cutr_nctr/39

This Technical Report is brought to you for free and open access by the National Center for Transit Research (NCTR) Archive (2000-2020) at Digital Commons @ University of South Florida. It has been accepted for inclusion in Research Reports by an authorized administrator of Digital Commons @ University of South Florida. For more information, please contact digitalcommons@usf.edu. 
SURLC 18-008

\section{Transit and Livability: Results from the National Community Livability Survey}

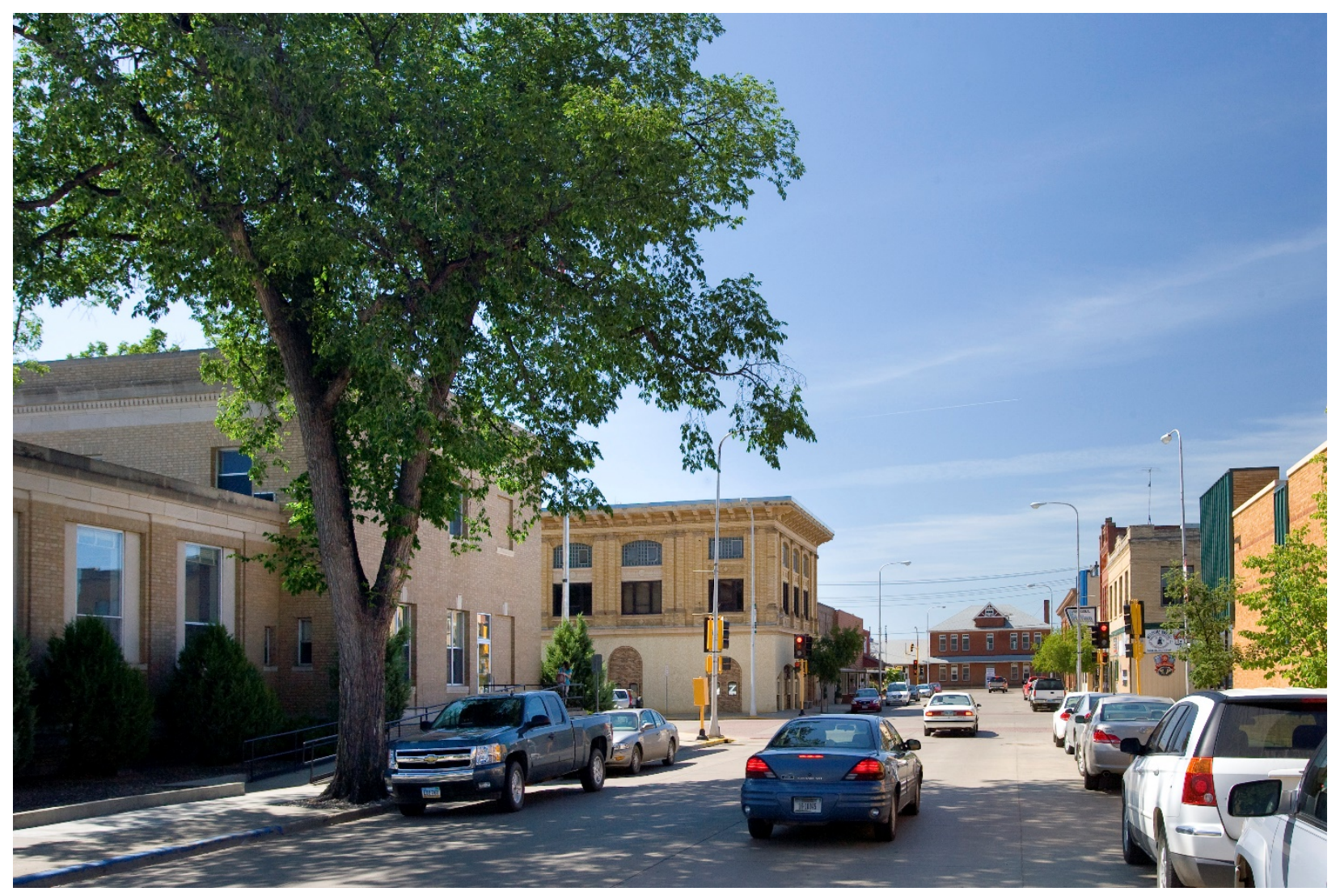

\section{Prepared for:}

U.S. Department of Transportation

Prepared by:

Ranjit Godavarthy Jeremy Mattson

Small Urban and Rural Transit Center Upper Great Plains Transportation Institute North Dakota State University

Fargo, ND

Jonathan Brooks

Jitendra Jain

Luca Quadrifoglio

Ipek Sener

Chris Simek

Texas A\&M Transportation Institute

College Station, TX

www.tti.tamu.edu

December 2018 


\section{Acknowledgments}

The study documented in this report was a partnership between the Small Urban and Rural Livability Center (SURLC) and the National Center for Transit Research (NCTR).

Support for study protocol development, survey data collection, and data processing was provided by Texas A\&M Transportation Institute (TTI) and NCTR, an academic consortium led by the University of South Florida: Center for Urban Transportation Research. The consortium is funded through the U.S. Department of Transportation's Office of the Assistant Secretary of Research and Technology as a University Transportation Center. The principal investigator for TTI was Jonathan Brooks, who is presently affiliated with LINK Houston in Houston, TX (www.linkhouston.org).

Support for data analysis, statistical modeling, and documentation was provided by SURLC, a partnership between the Western Transportation Institute at Montana State University and the Upper Great Plains Transportation Institute at North Dakota State University. The Center is funded through the U.S. Department of Transportation's Office of the Assistant Secretary of Research and Technology as a University Transportation Center. The Small Urban \& Rural Transit Center within the Upper Great Plains Transportation Institute at North Dakota State University conducted the research. The principal investigator for these study elements was Ranjit Godavarthy.

\section{Disclaimer}

The content presented in this report is the sole responsibility of the Small Urban and Rural Transit Center, the Upper Great Plains Transportation Institute, and the authors.

NDSU does not discriminate in its programs and activities on the basis of age, color, gender expression/identity, genetic information, marital status, national origin, participation in lawful offcampus activity, physical or mental disability, pregnancy, public assistance status, race, religion, sex, sexual orientation, spousal relationship to current employee, or veteran status, as applicable. Direct inquiries to: Vice Provost, Title IX/ADA Coordinator, Old Main 201, 701-231-7708, ndsu.eoaa@ndsu.edu. 


\section{ABSTRACT}

While many factors influence a community's livability, affordable transportation options such as transit services can be an important contributor. Availability and frequency of transit services vary greatly among metro and non-metro areas, thereby affecting the access to affordable transportation options. This study was Phase 3 of the three-phase livability study in researching the nexus of transit and livability in U.S. communities. The objective of the study was to conduct a National Community Livability Survey (NCLS) in both urban and rural communities in the United States and analyze the role of transportation and public transit toward quality of life.

The NCLS survey was distributed to 25,000 adults across all 50 U.S. states. The survey yielded a total of 994 high-quality responses, including 152 from transit riders who completed the transit rider survey questions. Survey results suggest that improving livability factors, such as affordable jobs, affordable housing, low crime, and affordable transportation options in metro communities, can improve the livability of metro residents. Similarly, improving livability factors, such as available jobs, affordable housing, quality healthcare, affordable transportation options, and overall cost of living, can improve the livability of non-metro communities. Further, when compared with metro communities, non-metro communities have a greater need to improve the identified livability factors, as there is a large need for improvement. 


\section{TABLE OF CONTENTS}

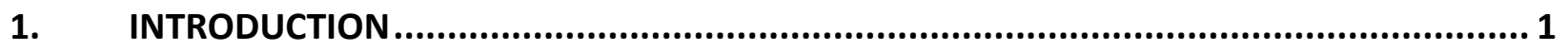

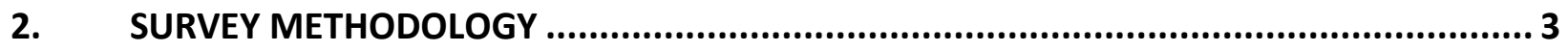

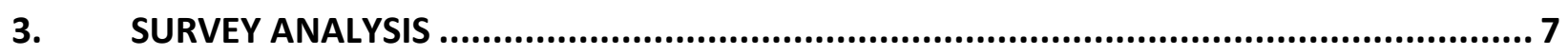

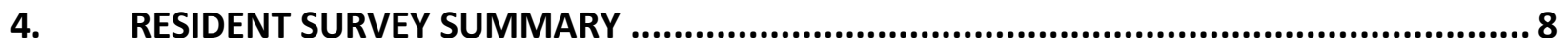

4.1 Respondents Socio-Demographic Characteristics ....................................... 8

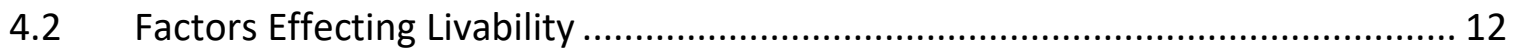

4.3 Importance of Various Aspects of Transportation to Community Livability ....... 13

4.4 Satisfaction with the Quality of Life in the Community...................................... 14

4.5 Quality of Each Livability Factor in Your Community ...................................... 14

4.6 Quality of Each Aspect of Transportation in Your Community........................... 18

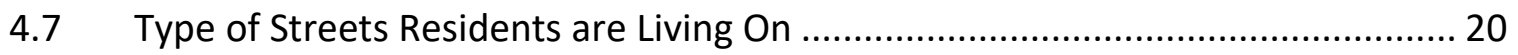

4.8 Phrase That Best Describes Your Community in Terms of Geographic Size........ 20

4.9 I Can Easily Travel to Places I Need to Go in My Community Using My Current Travel Options .......................................................................................... 21

4.10 How Many Days Do You Use Each Mode in a Typical Week?............................. 21

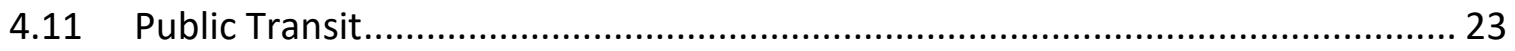

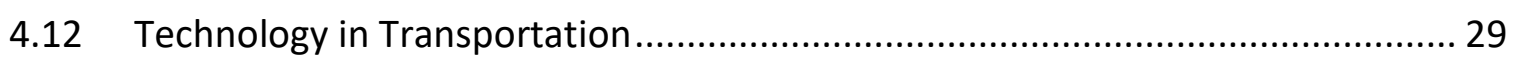

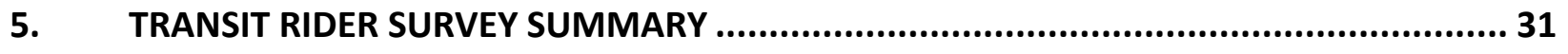

5.1 Transit Rider Respondent's Socio-Demographic Characteristics ....................... 31

5.2 Transit Usage and Characteristics............................................................... 34

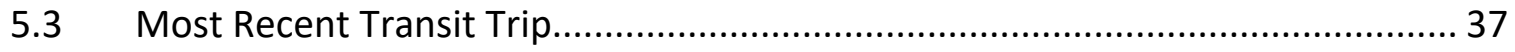

6. DATA ANALYSIS: IMPACTS OF TRANSPORTATION ON COMMUNITY QUALITY OF LIFE AND LIFE SATISFACTION ............................................................................... 40

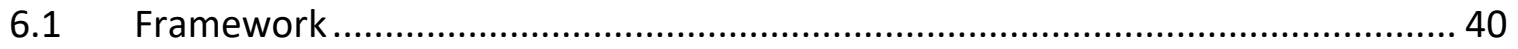

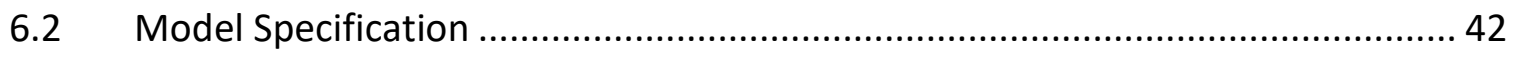

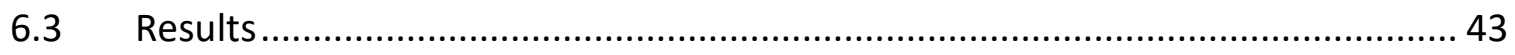

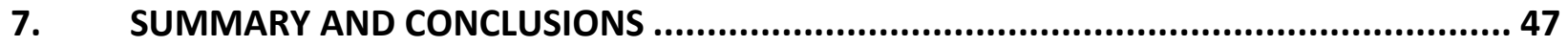

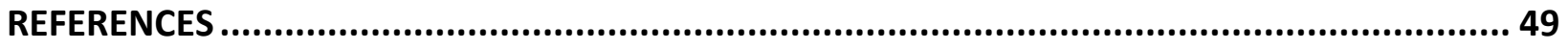




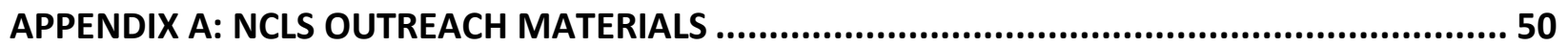

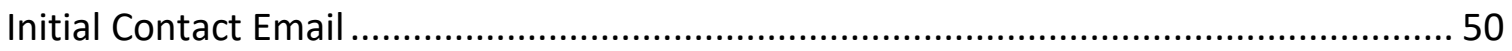

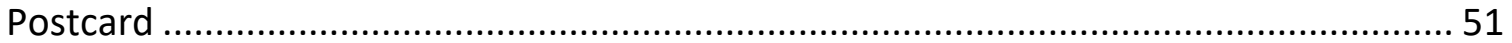

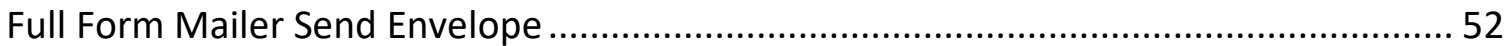

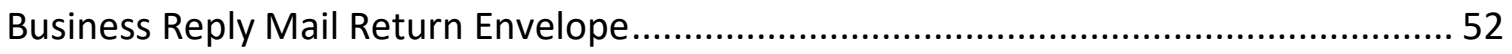

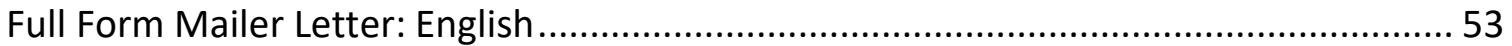

Full Form Mailer Letter: Spanish................................................................................. 54

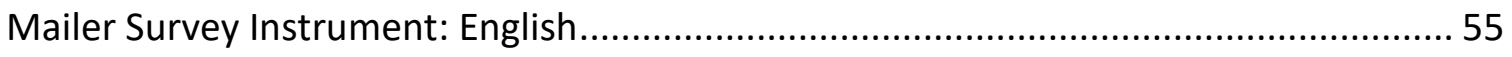

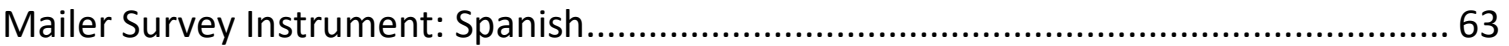




\section{LIST OF TABLES}

Table 2.1 Rural-Urban Continuum Codes ....................................................................... 4

Table 2.2 U.S. Adult Population Distribution by U.S. Regions and Rural-Urban Continuum

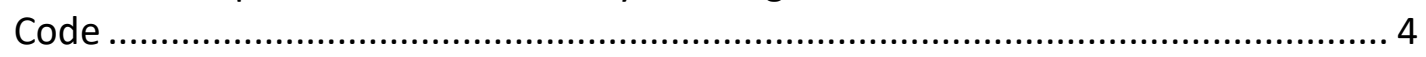

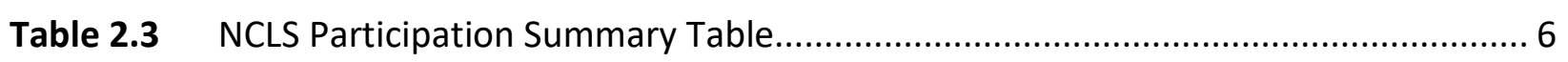

Table 4.1 How long have you lived in the community where you live?................................ 10

Table 4.2 In general, how would you rate your overall health? ......................................... 12

Table 4.3 Factors affecting community livability and their level of importance................... 13

Table 4.4 Various aspects of transportation and their importance .................................... 14

Table 4.5 Satisfaction with the quality of life in the community ...................................... 14

Table 4.6 Current quality of livability factors in your community..................................... 15

Table 4.7 Quality of each aspect of transportation in your community currently ................ 19

Table 4.8 Which of the following most closely describes the kind of .................................. 20

Table 4.9 What phrase best describes the way you define your community in terms of geographic size? ....................................................................................... 20

Table 4.10 How much do you agree or disagree with the following statement? "I can easily travel to places I need to go in my community using my current travel

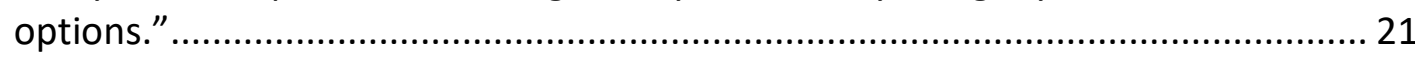

Table 4.11 How many days do you use each mode in a typical week? ................................. 22

Table 4.12 If you chose to, could you ride public transit from near your residence to the following types of places? ............................................................................. 25

Table 4.13 If you are able, and chose to, could you walk from your residence to the following types of places? ........................................................................... 25

Table 4.14 Why is it important to have public transit service in your community? ................ 26

Table 4.15 How much do you agree with the following statements about funding transit? ... 27

Table 4.16 Some transit riders pay a reduced fare. Who should be eligible for a

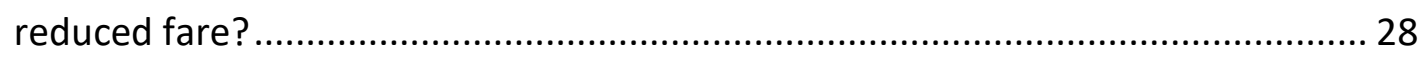

Table 4.17 How would the following statements change your use of transit?........................ 29

Table 4.18 Which of the following statements most likely describes your future vehicle

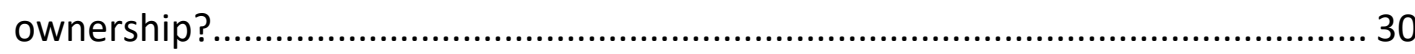

Table 4.19 How comfortable are you with the idea of an autonomous vehicle picking up and dropping you off for a personal business appointment? .............................. 30

Table 5.1 Why did you start riding public transit? .......................................................... 37

Table 5.2 If public transit had not been available, which one travel option would you

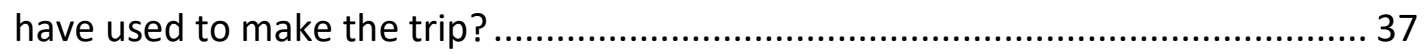

Table 5.3 When was your most recent trip on transit? ................................................... 38

Table 5.4 Which mode(s) of public transit did you use on the trip? .................................... 38

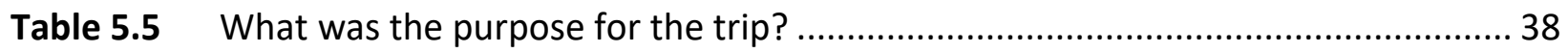


Table 5.6 How much do you agree or disagree with the following statements? .................. 39

Table 6.1 Livability Dimensions and Indicators ............................................................. 41

Table 6.2 Ordered Probit Results for Ease of Travel ..................................................... 44

Table 6.3 Ordered Probit Results for Community Quality of Life......................................... 44

Table 6.4 Ordered Probit Results for Life Satisfaction .................................................... 46 


\section{LIST OF FIGURES}

Figure 1.1 Rural Case Study Communities Studies in Phase 1 and Phase 2 ........................... 1

Figure 2.1 Four U.S. Regions and Nine Census Divisions.............................................. 3

Figure 2.2 County Rural-Urban Continuum Code 2013, USDA ERS.................................... 4

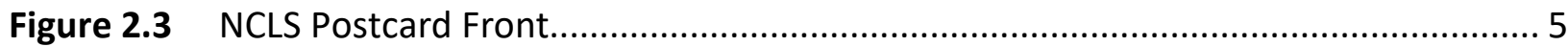

Figure 4.1 Percentage of respondents by age distribution for metro and non-metro areas.... 8

Figure 4.2 Including yourself, how many people live in your household? ............................ 9

Figure 4.3 Percentage of respondents by race ............................................................. 9

Figure 4.4 How many working vehicles (cars, trucks, and motorcycles) are available in

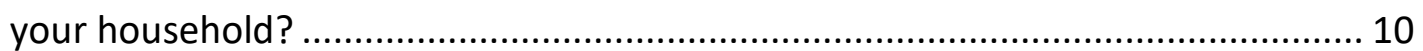

Figure 4.5 Which of the following best describes your current employment status? ............ 11

Figure 4.6 What is the combined annual income for all people living in your household?.... 11

Figure 4.7 Metro Areas: Importance of livability factors in a general community vs. quality of livability factors in the current community ........................................ 16

Figure 4.8 Non-metro Areas: Importance of livability factors in a general community vs. quality of livability factors in the current community

Figure 4.9 Gap between livability factors' importance in general community and quality in current communities

Figure 4.10 Gap between various transportation aspects' importance in general community and quality in current communities 19

Figure 4.11 Public transit availability, usage, and interest 24

Figure 4.12 How much do you agree or disagree with the following statement?

"It is important for public transit to be available to my community's residents."

Figure 4.13 Do you support more transit, less transit, or the same amount of transit

in your community, given that public funds are needed to support part of the cost?

Figure 4.14 In general, how much of the total operating cost of transit should come from rider fares?

Figure 5.1 Transit riders - Percentage of respondents by age distribution for metro

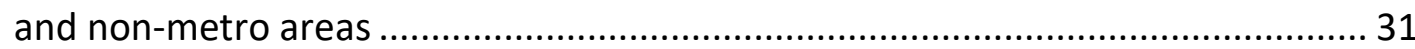

Figure 5.2 Transit riders - Including yourself, how many people live in your household?....... 32

Figure 5.3 Transit riders - Percentage of respondents by race ......................................... 32

Figure 5.4 How many working vehicles (cars, trucks, and motorcycles) are available in

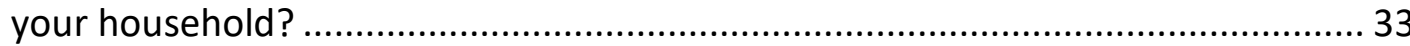

Figure 5.5 Which of the following best describes your current employment status? ............. 33

Figure 5.6 What is the combined annual income for all people living in your household?.... 34

Figure 5.7 How often do you ride public transit? ............................................................... 35

Figure 5.9 How likely is it that you would recommend the public transit service you ride

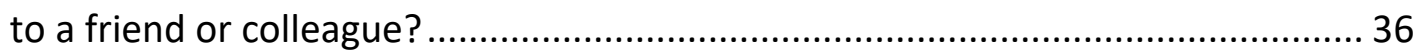

Figure 6.1 Survey Respondent Life Satisfaction Ratings, Metro vs. Non-Metro .................... 42 


\section{INTRODUCTION}

Community quality of life and livability are synonymous terms used to describe the degree to which communities contribute to an individual's overall quality of life. While many factors influence a community's livability, affordable transportation options, such as transit services, can be an important contributor in both large and small communities. Although the quality of transit service is greater in urban communities, with more days and hours of service, public transit in rural areas provides critical lifeline services to transit-dependent people by connecting them to health care services, educational institutions, employment, and other important activities. Public transit services can be very important for improving the quality of life of transit-dependent populations in both metro and non-metro areas.

This study is the final phase of the three-phase livability study in researching the nexus of transit and livability in U.S. communities. Phase 1 and Phase 2 focused on studying the nexus of transit and livability in rural communities by conducting case studies of six rural communities, including West Columbia, TX; Bath, ME; Hannibal, MO; Woodburn, OR; Dickinson, ND; and Valley City, ND (Figure 1.1) (Brooks, Edrington, Sharma, Vasishth, \& Cherrington, 2014) (Brooks, Sharma, Pappas, \& Cherrington, 2015) (Godavarthy \& Mattson, 2016). For each of the six rural case study communities, resident surveys, transit rider's surveys, and stakeholder interviews were conducted to investigate the community's perspective of livability, the importance of various factors contributing to the rural community's livability and quality of life, and transit's importance to livability. The Small Urban and Rural Transit Center at North Dakota State University collaborated with the Texas Transportation Institute in Phase 2 and Phase 3 of the transit livability studies (Brooks, Sharma, Pappas, \& Cherrington, 2015) (Godavarthy \& Mattson, 2016).

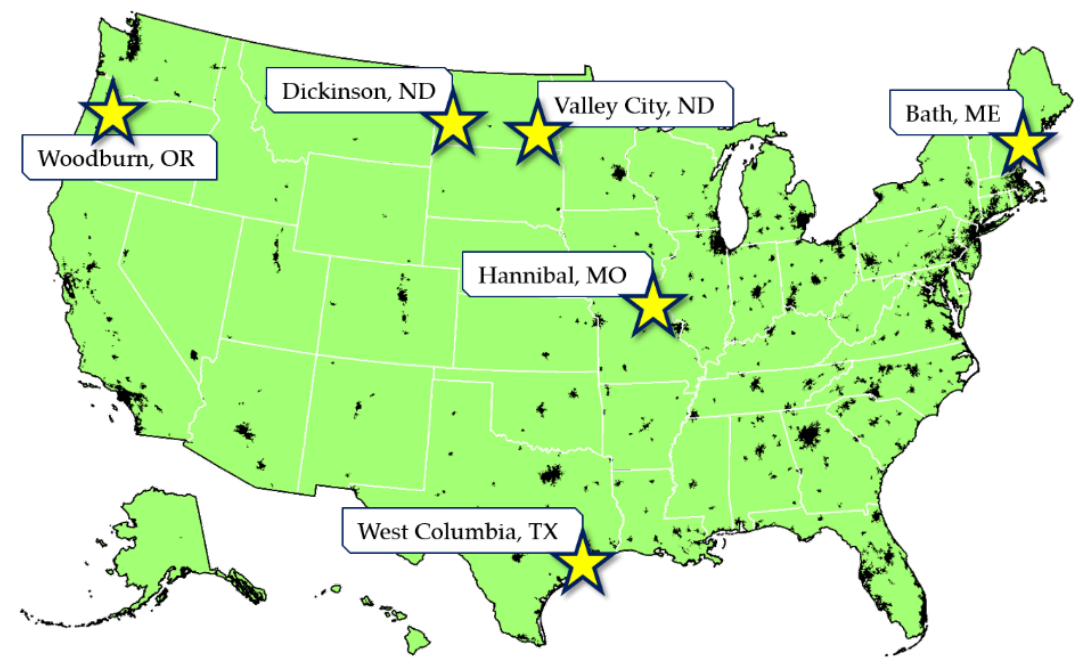

Figure 1.1 Rural Case Study Communities Studies in Phase 1 and Phase 2 Source: Forthcoming report: "National Community Livability Survey: Methodology, Summary, Data," Jonathan Brooks et al., 2018 
The major objective of Phase 3 of the livability study was to conduct a National Community Livability Survey (NCLS) in both metro urban and non-metro rural communities in the United States and analyze the role of transportation and public transit toward quality of life. Further responses from metro areas will be compared with non-metro areas to understand any similarities or differences in how transportation and public transit plays a role in the livability and quality of life of respective community residents. 


\section{SURVEY METHODOLOGY}

The National Community Livability Survey (NCLS) was conducted from April 20, 2017, to December 9, 2017. The research team contacted 25,000 adults from all 50 U.S. states. The survey was split into two stratified waves of outreach: 14,000 potential participants were contacted in stage one, and an additional 11,000 potential participants were contacted in stage two. NCLS was a stratified random sample survey to ensure that the survey distribution was proportional to U.S. adult non-institutionalized population (Brooks et al., forthcoming). The research team stratified the NCLS random survey outreach by four U.S. regions and nine census divisions (Figure 2.1). The random survey was further stratified by sex and age to ensure research participants were proportional to the adult population in each area (Brooks et al., forthcoming).

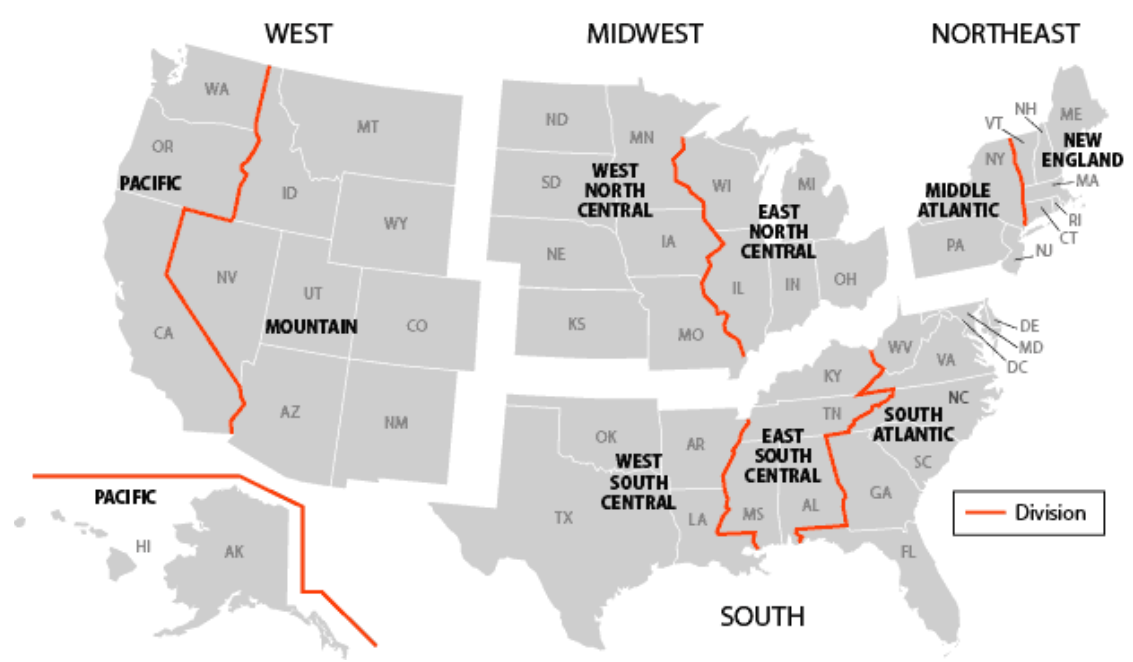

Figure 2.1 Four U.S. Regions and Nine Census Divisions.

Source: Forthcoming report: National Community Livability Survey: Methodology, Summary, Data, Jonathan Brooks et al., 2018

Further, the research team stratified NCLS outreach by the U.S. Department of Agriculture (USDA): Economic Research Service (ERS) Rural-Urban Continuum Code (RUCC) to ensure random sampling would reach an equal number of adults living in each of the nine classifications (Figure 2.2). USDA ERS classifies each county as one of nine RUCC codes based on the population and adjacency to other counties (Table 2.1). In this study, communities with RUCC codes 1, 2, and 3 are considered metro areas and communities; RUCC codes 4-9 are considered non-metro areas for comparison purposes. While $85 \%$ of the U.S. population is located in communities with RUCC codes 1, 2, and 3 (metro areas) (see Table 2.2 for population distribution according to U.S. regions and RUCC code), the research team contacted roughly an equal number of adults in each of the nine RUCC classifications, which meant rural communities were over-sampled to ensure a comparable sample size of returned survey responses. 


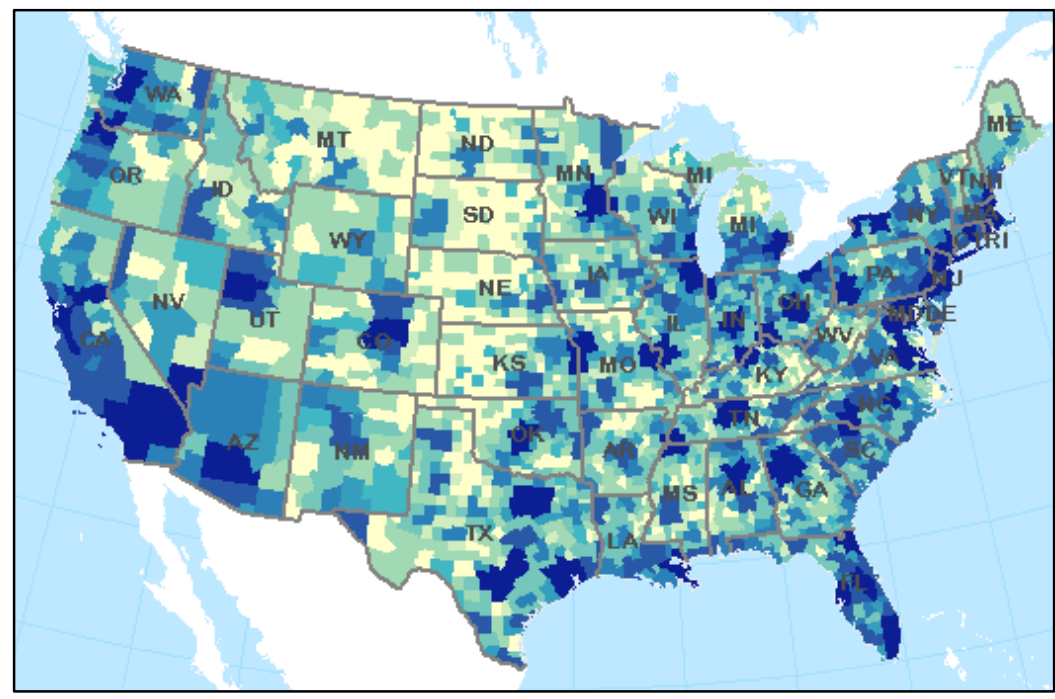

Classification

Metro - population 1 million or more

Metro - population 1 mil. - 250, 000

Metro - fewer than 250,000 pop.

Urban pop. $20,000+$ adj.

Urban pop. 20,000 + not adj.

Urban pop. 2,500-19,999 adj.

Urban pop. 2,500 - 19,999 not adj.

Completely rural - adjacent

Completely rural - not adjacent

Figure 2.2 County Rural-Urban Continuum Code 2013, USDA ERS. Source: Forthcoming report: National Community Livability Survey: Methodology, Summary, Data, Jonathan Brooks et al., 2018

Table 2.1 Rural-Urban Continuum Codes

\begin{tabular}{cl}
\hline Code & Description \\
\hline 1 & Counties in metro areas of 1 million population or more \\
2 & Counties in metro areas of 250,000 to 1 million population \\
3 & Counties in metro areas of fewer than 250,000 population \\
4 & Urban population of 20,000 or more, adjacent to a metro area \\
5 & Urban population of 20,000 or more, not adjacent to a metro area \\
6 & Urban population of 2,500 to 19,999, adjacent to a metro area \\
7 & Urban population of 2,500 to 19,999, not adjacent to a metro area \\
8 & Completely rural or less than 2,500 urban population, adjacent to a metro area \\
9 & Completely rural or less than 2,500 urban population, not adjacent to a metro area
\end{tabular}

Table 2.2 U.S. Adult Population Distribution by U.S. Regions and Rural-Urban Continuum Code

\begin{tabular}{|c|c|c|c|c|c|c|c|c|c|c|c|c|c|c|c|c|c|c|c|c|}
\hline \multirow[b]{2}{*}{ Region } & \multicolumn{10}{|c|}{ USDA 2013 County Rural Urban Continuum Code } & \multicolumn{10}{|c|}{ USDA 2013 County Rural Urban Continuum Code } \\
\hline & 1 & 2 & 3 & 4 & 5 & 6 & 7 & 8 & 9 & TOTAL & 1 & 2 & 3 & 4 & $\begin{array}{l}4 \\
+\end{array}$ & 6 & 67 & 8 & & TOTAL \\
\hline Northeast & 29.3 & 8.6 & 2.3 & 1.9 & 0.14 & 0.93 & 0.58 & 0.08 & 0.05 & 43.8 & $12.1 \%$ & $3.5 \%$ & $0.9 \%$ & $60.8 \%$ & $60.1 \%$ & $0.4 \%$ & $0.2 \%$ & $0.03 \%$ & $0.02 \%$ & $6 \quad 18 \%$ \\
\hline Midwest & 24.1 & 9.3 & 6.5 & 3.4 & 1.1 & 3.8 & 2.1 & 0.56 & 0.88 & 51.7 & $10.0 \%$ & $3.8 \%$ & $2.7 \%$ & $1.4 \%$ & $6.5 \%$ & $1.6 \%$ & $0.9 \%$ & $0.2 \%$ & $0.4 \%$ & $21 \%$ \\
\hline South & 45.1 & 21.4 & 8.8 & 3.8 & 1.3 & 5.8 & 2.6 & 1.0 & 0.84 & 90.5 & $18.6 \%$ & $8.8 \%$ & $3.6 \%$ & $1.6 \%$ & $0.5 \%$ & $2.4 \%$ & $1.1 \%$ & $0.4 \%$ & $0.3 \%$ & $37 \%$ \\
\hline West & 34.9 & 12.0 & 4.5 & 1.4 & 1.3 & 0.89 & 1.1 & 0.12 & 0.26 & 56.5 & $14.4 \%$ & $5.0 \%$ & $1.9 \%$ & $0.6 \%$ & $6.5 \%$ & $0.4 \%$ & $0.5 \%$ & $0.05 \%$ & $0.1 \%$ & $23 \%$ \\
\hline TOTAL & 133.3 & 51.3 & 22.1 & 10.5 & 3.8 & 11.4 & 6.4 & 1.8 & 2.0 & 242.6 & $55 \%$ & $21 \%$ & $9 \%$ & $4 \%$ & $2 \%$ & $5 \%$ & 3\% & $1 \%$ & $1 \%$ & $100 \%$ \\
\hline
\end{tabular}

Source: Forthcoming report: National Community Livability Survey: Methodology, Summary, Data, Jonathan Brooks et al., 2018 
The NCLS survey instrument was designed with 55 questions that focused on general community livability; local community livability; community characteristics; transportation; public transit awareness, availability, and interest; walkability; funding support for public transit, technology, and future transportation; socio-demographic characteristics; and followup questions for respondents who are transit riders. The research team purchased contact details from a leading domestic address vendor, which included information such as physical mailing address, e-mail, sex (male/female), and estimated age. Physical address was the only parameter used for random sampling purposes.

Potential survey respondents were initially contacted via mail using a 4" $\times$ 6" postcard (Figure 2.3) that invited participants to take the online survey, which was available in five languages: English, Spanish, Chinese, Korean, and Vietnamese. Later, an e-mail invitation was sent to participants with an available e-mail address. Finally, each participant was sent a physical mailer, which included an invitation letter, survey form, and business-reply-mail envelope. The physical survey was available in both English and Spanish. Survey participants were offered an incentive of a \$3 Amazon gift card for their returned survey response. Appendix A contains copies of English and Spanish versions of the survey instrument and other outreach materials used in the study.

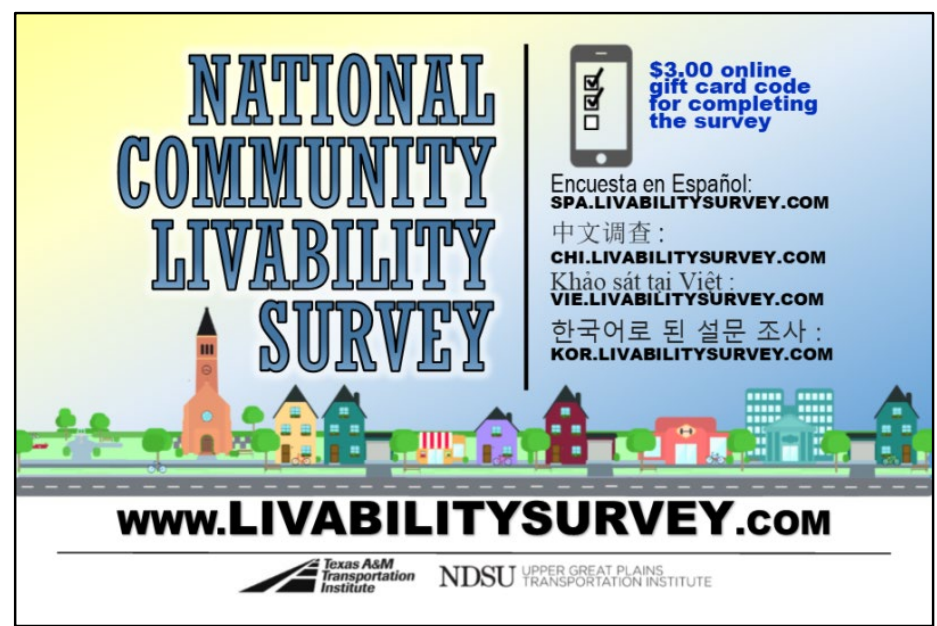

Figure 2.3 NCLS Postcard Front

Source: Forthcoming report: National Community Livability

Survey: Methodology, Summary, Data, Jonathan Brooks et al., 2018

Among the total 25,000 surveys distributed, a total of 994 high-quality responses were received (Brooks et al., forthcoming). Survey responses were roughly in proportion with the sample stratification designed in outreach efforts, and the responses were nearly equally geographically distributed and between the RUCC codes. Table 2.3 illustrates how survey responses compare with region and RUCCs. However, NCLS was strategically sampled to achieve roughly equal participation in each of the nine county types (Brooks et al., forthcoming). 
Table 2.3 NCLS Participation Summary Table

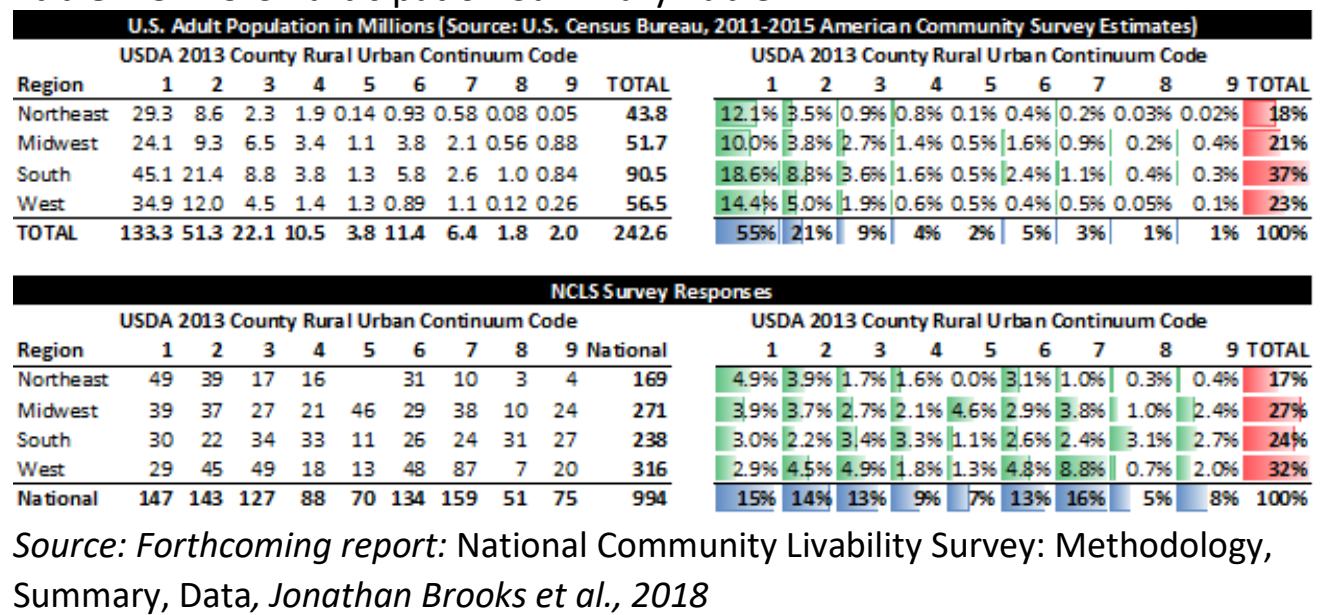




\section{SURVEY ANALYSIS}

Among the 55 questions included in the NCLS survey instrument, the first 30 were aimed toward asking residents about community livability, community characteristics, transportation, public transit awareness/availability/interest, walkability, funding support for public transit, technology, and future transportation. Fifteen questions were aimed at gathering survey respondent's socio-demographic characteristics. One open-ended question gave respondents the opportunity to provide additional comments about community livability and public transit. The last nine questions of the survey were included as follow-up questions for potential survey participants who are transit users. The survey analysis and results were categorized as resident survey results and transit rider survey results. The total number of 994 NCLS survey responses were considered as resident survey responses. Among 994 responses, 152 respondents who were transit riders completed the follow-up transit rider survey questionnaire; therefore, the 152 completed transit rider survey responses were used to analyze national transit rider survey results.

A survey analysis for the 994 NCLS responses will also be categorized and analyzed as responses and results for metro areas (survey responses associated with RUCC codes 1, 2, and 3), nonmetro areas (RUCC codes 4-9), and, when appropriate, an overall summary combining both metro and non-metro areas. Among the 994 NCLS responses, 417 (42\%) responses are from metro areas, and 577 (58\%) responses are from non-metro areas.

Objectives of the study analysis include synthesizing various NCLS survey responses categorized as metro or non-metro respondents. Further, NCLS survey respondents who also completed the follow-up transit rider survey will be analyzed for transit rider survey responses. 


\section{RESIDENT SURVEY SUMMARY}

\subsection{Respondents Socio-Demographic Characteristics}

Among the 994 respondents, $58.8 \%$ are female and $41.2 \%$ are male. Non-metro areas had a slightly higher percentage of female respondents ( $60 \%$ female, $40 \%$ male) compared with metro areas ( $57.1 \%$ female, $42.9 \%$ male). The highest percentage of respondents in both metro and non-metro areas are 55 to 64 years old, followed by 64 to 74 years old, and 45 to 54 years old. Refer to Figure 4.1 for percentage of respondents by age distribution for metro and nonmetro areas. Close to half of the respondents in metro and non-metro areas lived in a twoperson household (Figure 4.2). Most of the respondents in both metro and non-metro areas are white, although comparatively more white respondents were observed in non-metro areas (Figure 4.3).

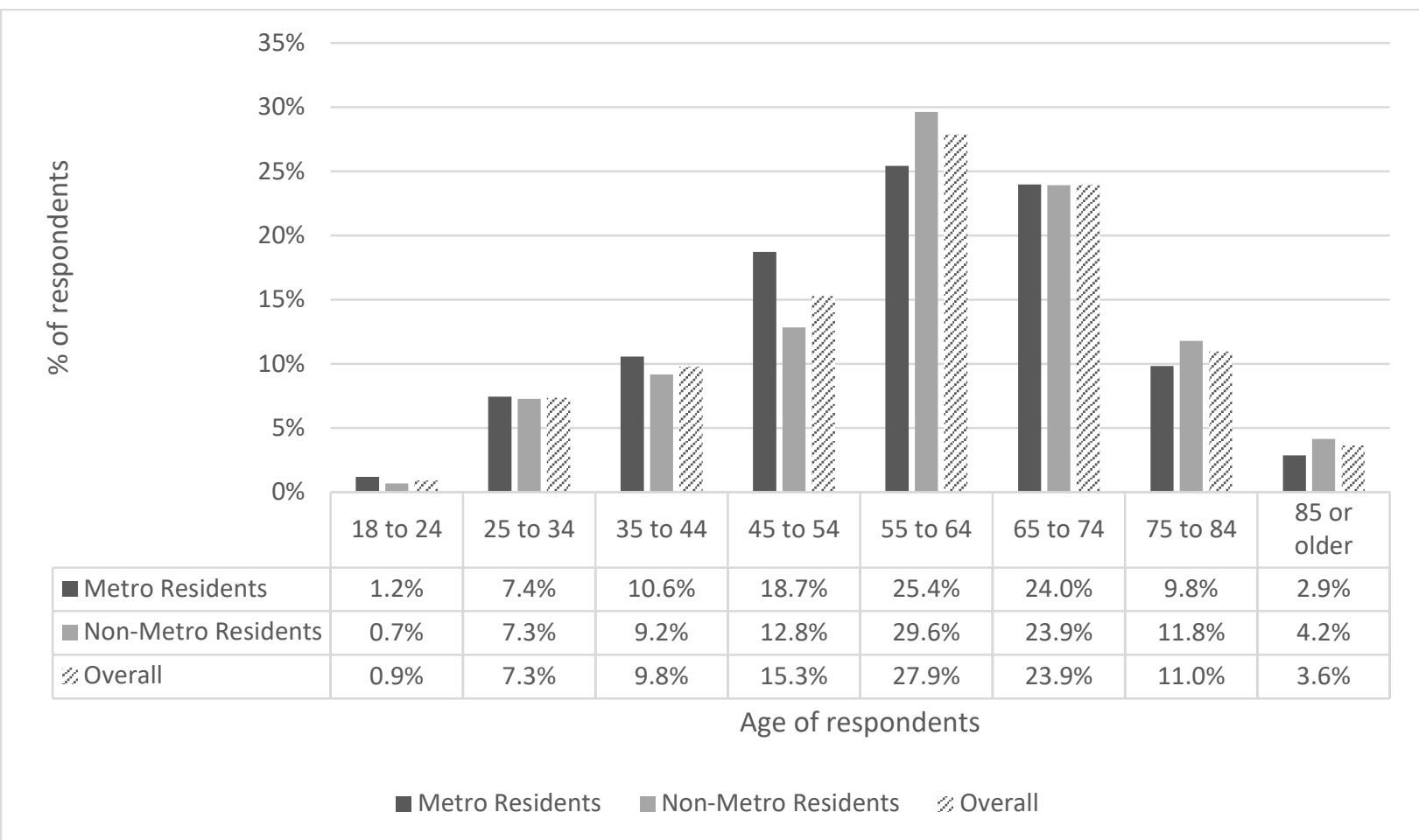

Figure 4.1 Percentage of respondents by age distribution for metro and non-metro areas 


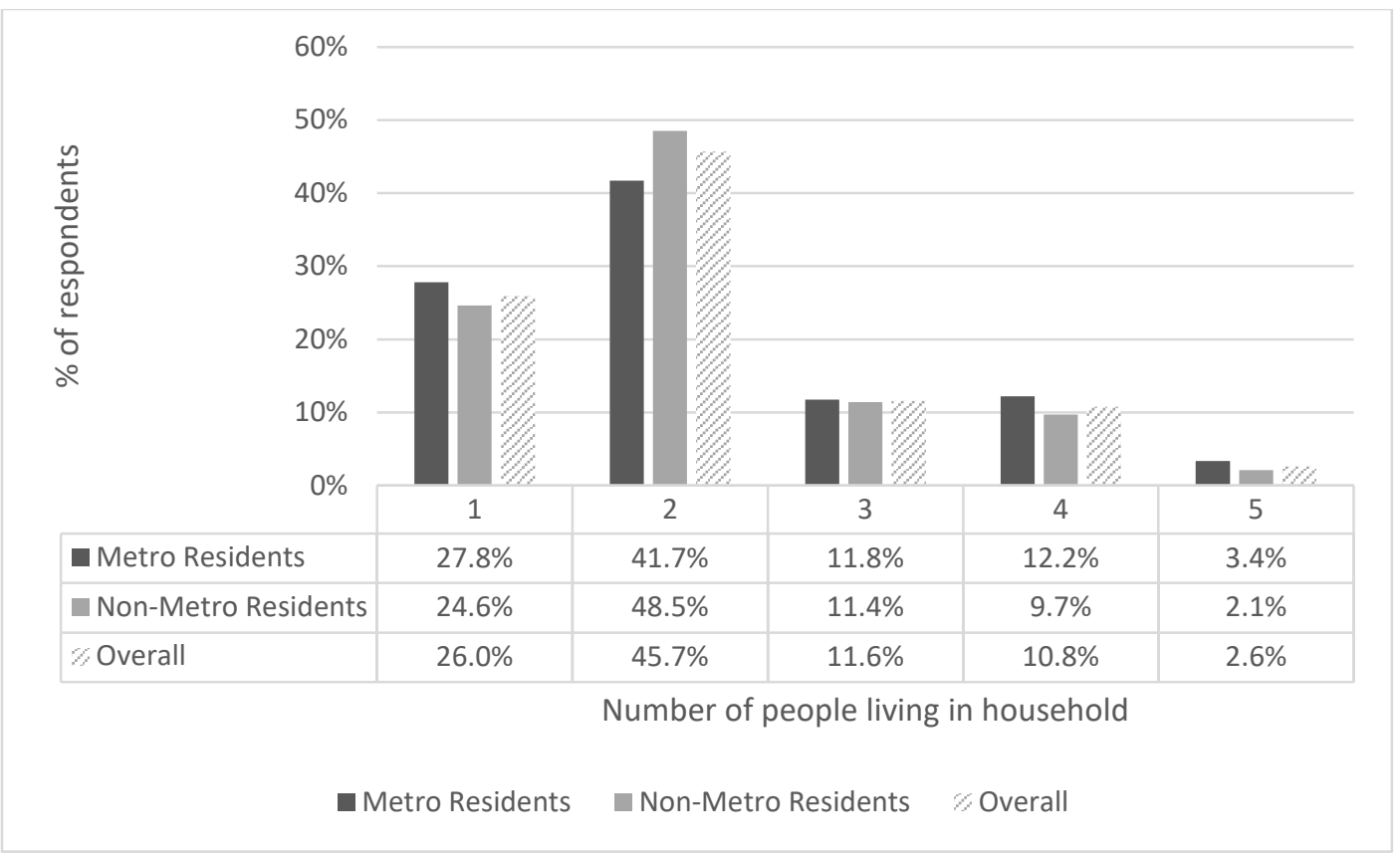

Figure 4.2 Including yourself, how many people live in your household?

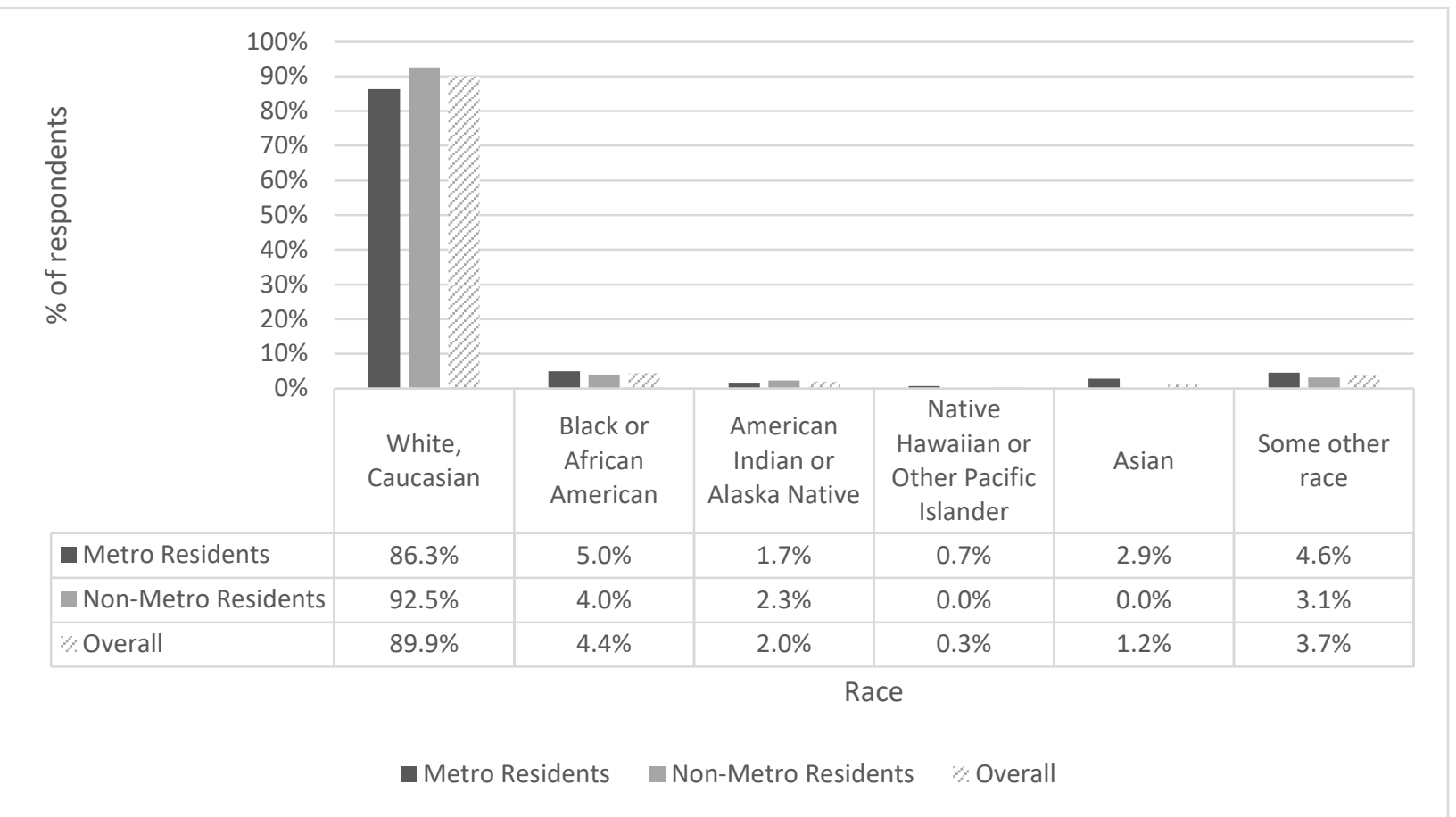

Figure 4.3 Percentage of respondents by race

About half of the residents responding from metro and non-metro areas lived in their communities for more than 20 years, although more non-metro residents were observed to be living in their communities for more than 20 years (Table 4.1). 
Table 4.1 How long have you lived in the community where you live?

\begin{tabular}{|l|r|r|r|r|r|}
\hline & $\begin{array}{c}\text { Less than } \\
1 \text { year }\end{array}$ & $\begin{array}{c}1 \text { to } 5 \\
\text { years }\end{array}$ & $\begin{array}{c}6 \text { to } 10 \\
\text { years }\end{array}$ & $\begin{array}{c}11 \text { to } 20 \\
\text { years }\end{array}$ & $\begin{array}{c}\text { More } \\
\text { than 20 } \\
\text { years }\end{array}$ \\
\hline Metro Residents & $3.4 \%$ & $13.4 \%$ & $9.4 \%$ & $22.3 \%$ & $50.6 \%$ \\
\hline Non-Metro Residents & $1.4 \%$ & $13.3 \%$ & $12.0 \%$ & $16.3 \%$ & $56.7 \%$ \\
\hline Overall & $2.2 \%$ & $13.4 \%$ & $10.9 \%$ & $18.8 \%$ & $54.1 \%$ \\
\hline
\end{tabular}

Most of the metro residents (95.9\%) and non-metro residents (95.5\%) have a driver's license. The largest share of the respondents (37.2\% of metro residents and $40.6 \%$ of non-metro residents) mentioned they have two working vehicles (cars, trucks, or motorcycles) in their household (Figure 4.4). Most of the respondents are either employed full time or retired (Figure 4.5). Annual income of respondents is fairly evenly distributed (Figure 4.6). The rate of mobility impairment was greater in non-metro areas, as $19.8 \%$ of non-metro respondents and $11.5 \%$ of metro respondents reported they have difficulty walking or climbing stairs. The use of a wheelchair or other mobility assistive devices to travel outside their residence was reported by $4.6 \%$ of metro respondents and $6.2 \%$ of non-metro respondents. In general, most of the respondents from metro (72.2\%) and non-metro (68.1\%) communities mentioned that their overall health is good (Table 4.2).

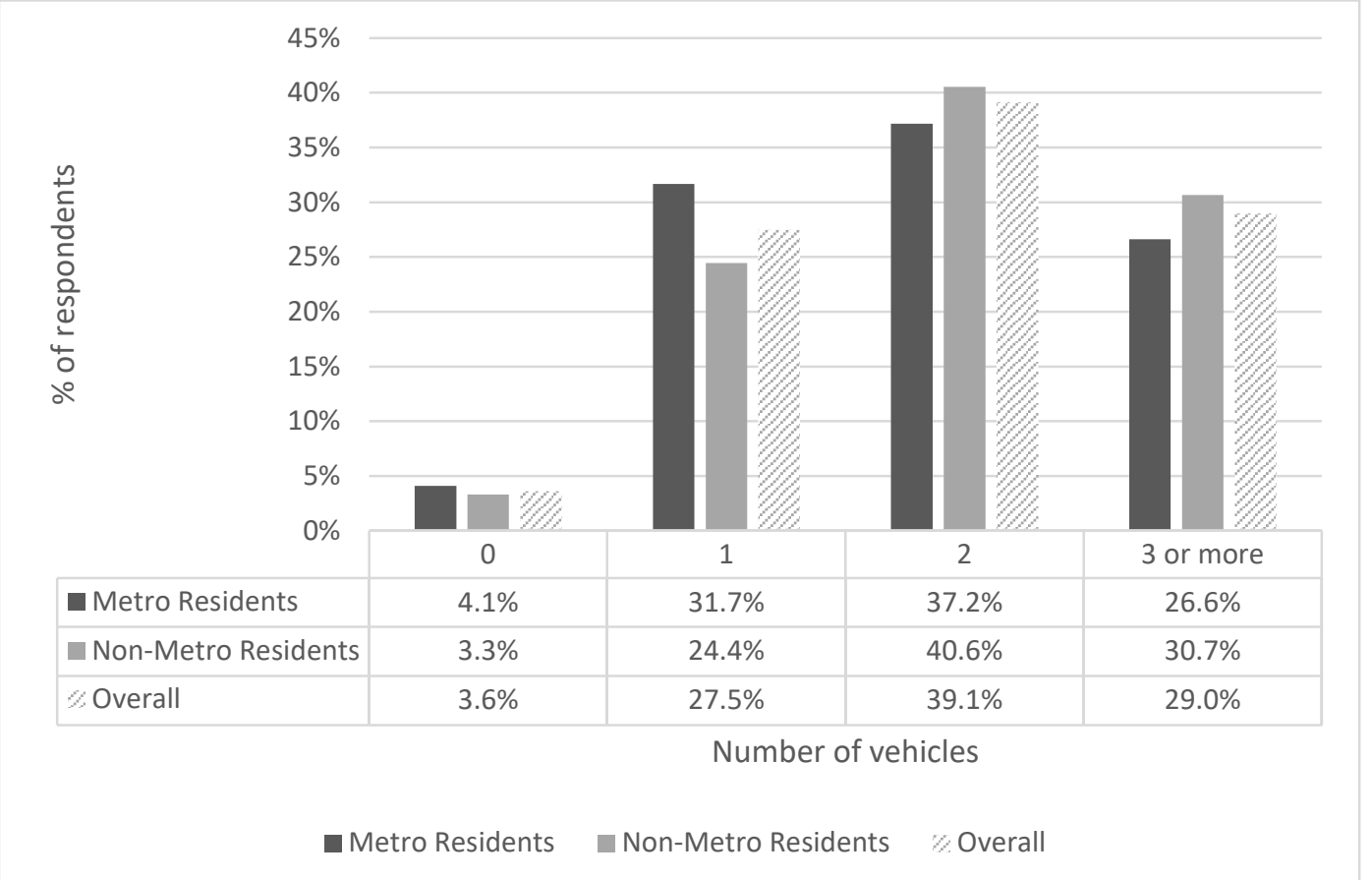

Figure 4.4 How many working vehicles (cars, trucks, and motorcycles) are available in your household? 


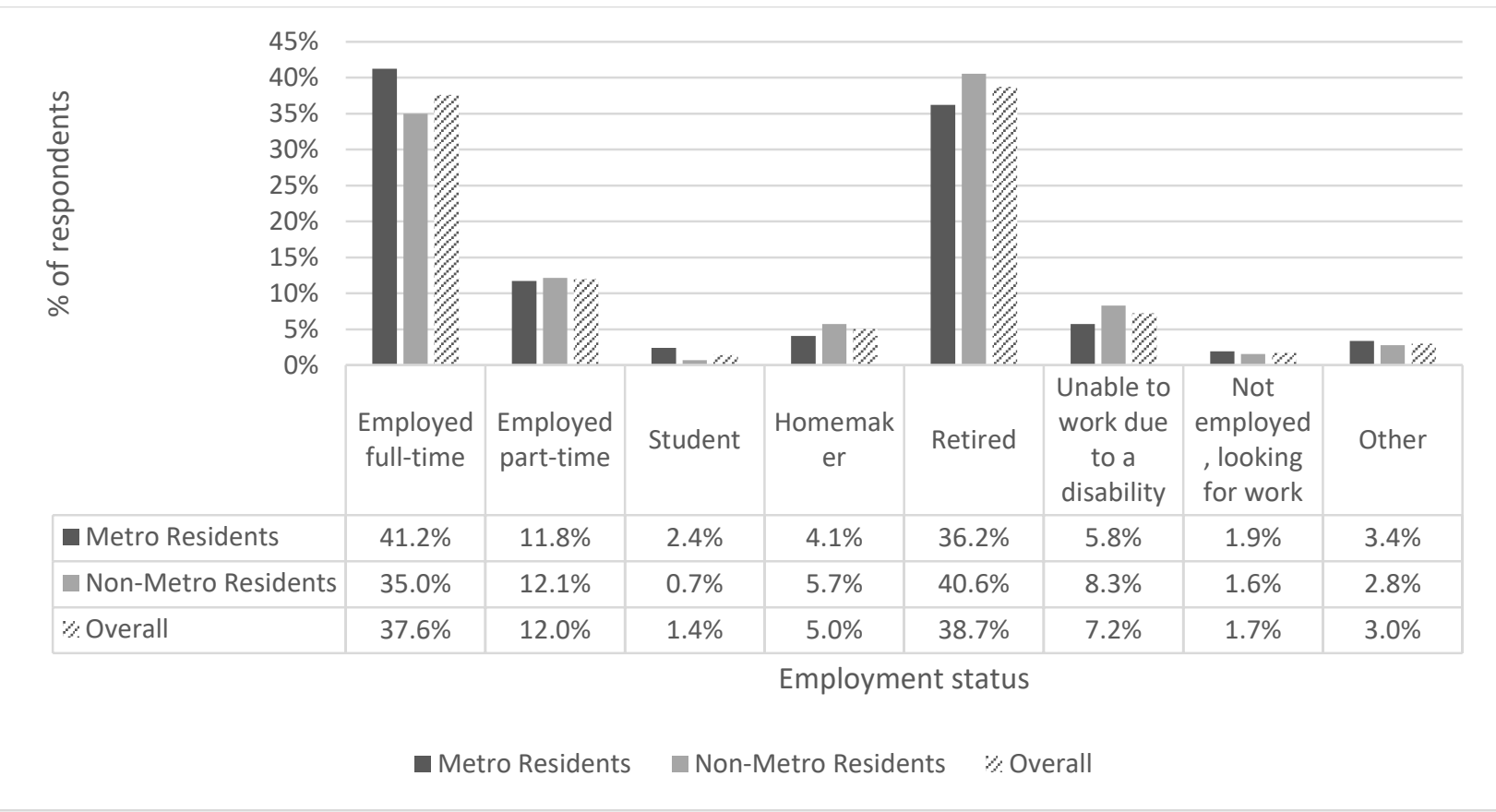

Figure 4.5 Which of the following best describes your current employment status?

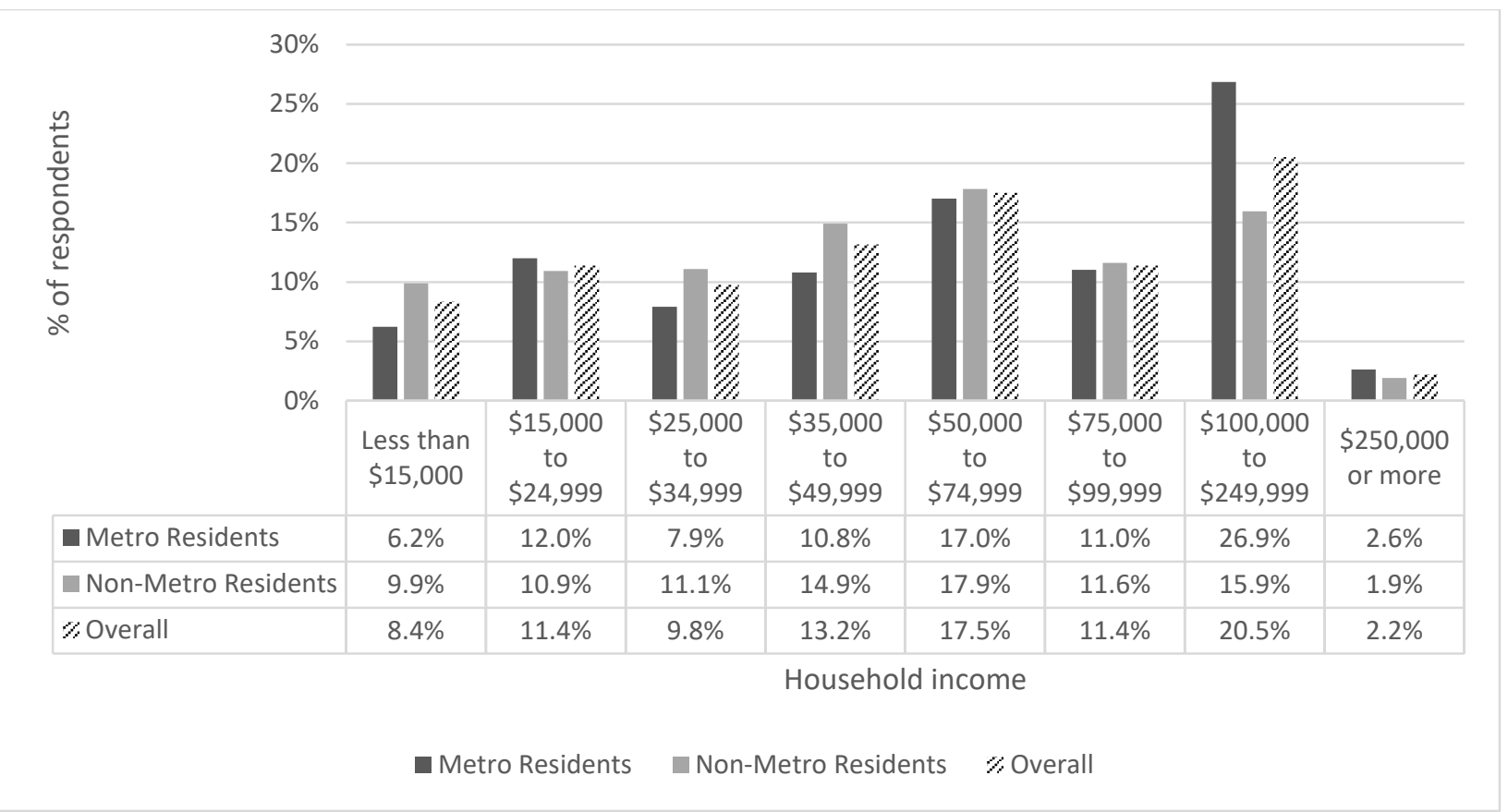

Figure 4.6 What is the combined annual income for all people living in your household? 
Table 4.2 In general, how would you rate your overall health?

\begin{tabular}{|l|c|c|c|} 
& $\begin{array}{c}\text { Metro } \\
\text { Residents }\end{array}$ & $\begin{array}{c}\text { Non-Metro } \\
\text { Residents }\end{array}$ & Overall \\
\hline Poor & $2.9 \%$ & $4.2 \%$ & $3.6 \%$ \\
\hline Fair & $24.7 \%$ & $27.0 \%$ & $26.1 \%$ \\
\hline Good & $72.2 \%$ & $68.1 \%$ & $69.8 \%$ \\
\hline
\end{tabular}

\subsection{Factors Affecting Livability}

The survey listed a number of potential livability factors and asked respondents to rate the importance of each factor to the livability of any community. Respondents had to rate each factor as: 1 = not important, 2 = slightly important, 3 = moderately important, $4=$ important, and $5=$ very important. Average responses are shown in Table 4.3. Available jobs, quality healthcare, quality public schools, low crime, affordable housing, overall cost of living, and clean environment are considered by both metro and non-metro residents as factors that are very important (>4) for community livability.

The top five factors identified as affecting community livability for both metro and non-metro residents are available jobs, quality healthcare, quality public schools, low crime, and affordable housing. While each livability factor had almost the same level of importance among metro and non-metro residents, affordable transportation options, cultural institutions, parks and recreation facilities, shopping and entertainment options, and quality healthcare are factors that are determined to be more important to metro residents when compared with non-metro residents. Similarly, sense of community, overall cost of living, and available jobs are determined to be more important to non-metro residents when compared with metro residents. 
Table 4.3 Factors affecting community livability and their level of importance

\begin{tabular}{|l|c|c|c|}
\hline & $\begin{array}{c}\text { Metro } \\
\text { Residents }\end{array}$ & $\begin{array}{c}\text { Non- } \\
\text { Metro } \\
\text { Residents }\end{array}$ & Overall \\
\hline Available jobs & 4.5 & 4.6 & 4.5 \\
\hline $\begin{array}{l}\text { Affordable transportation } \\
\text { options }\end{array}$ & 4.0 & 3.7 & 3.8 \\
\hline Cultural institutions & 3.5 & 3.2 & 3.4 \\
\hline Quality healthcare & 4.6 & 4.5 & 4.6 \\
\hline Affordable housing & 4.4 & 4.4 & 4.4 \\
\hline Quality public schools & 4.5 & 4.5 & 4.5 \\
\hline Overall cost of living & 4.3 & 4.4 & 4.4 \\
\hline $\begin{array}{l}\text { Shopping and entertainment } \\
\text { options }\end{array}$ & 3.6 & 3.5 & 3.5 \\
\hline Parks and recreation facilities & 3.8 & 3.6 & 3.7 \\
\hline Weather & 3.5 & 3.5 & 3.5 \\
\hline Clean environment & 4.3 & 4.3 & 4.3 \\
\hline Low crime & 4.5 & 4.5 & 4.5 \\
\hline Sense of community & 3.8 & 3.9 & 3.9 \\
\hline Traffic safety & 4.0 & 4.0 & 4.0 \\
\hline
\end{tabular}

Note: Scale: 1 = not important, 2 = slightly important, 3 = moderately important, $4=$ important, and $5=$ very important.

\subsection{Importance of Various Aspects of Transportation to Community Livability}

Again, thinking of any community in America, respondents were asked to indicate the level of importance of various aspects of transportation, including public transit services, bikeability, low traffic congestion, walkability/accessibility, and roads in good condition. Level of importance is numerically assigned 1-5 for not important, slightly important, moderately important, important, and very important for analysis purposes.

Results for the level of importance of each aspect of transportation to community livability are summarized in Table 4.4 for metro and non-metro areas. Having roads in good condition was summarized as a very important (average importance numeric $>4$ ) aspect of transportation to community livability by both metro and non-metro residents, followed by low traffic congestion, which was summarized to be important. In metro areas, apart from low traffic congestion, walkability/accessibility was also observed as the second most important aspect of transportation to community livability. It is also interesting to observe that when compared with non-metro areas, having public transit services in metro areas was considered more important to community livability, which could be because a greater percentage of metro 
residents have accessible public transit options and tend to use them more often. However, public transit services are still observed to be important for non-metro residents.

Table 4.4 Various aspects of transportation and their importance

\begin{tabular}{|l|c|c|c|}
\hline & $\begin{array}{c}\text { Metro } \\
\text { Residents }\end{array}$ & $\begin{array}{c}\text { Non- } \\
\text { Metro } \\
\text { Residents }\end{array}$ & Overall \\
\hline Public transit services & 3.6 & 3.2 & 3.4 \\
\hline Bikeability & 3.1 & 2.9 & 3.0 \\
\hline Low traffic congestion & 3.7 & 3.7 & 3.7 \\
\hline $\begin{array}{l}\text { Walkability / } \\
\text { accessibility }\end{array}$ & 3.7 & 3.5 & 3.6 \\
\hline $\begin{array}{l}\text { Roads in good } \\
\text { condition }\end{array}$ & 4.2 & 4.3 & 4.3 \\
\hline
\end{tabular}

Note: Scale: 1 = not important, 2 = slightly important, $3=$ moderately important, $4=$ important, and $5=$ very important .

\subsection{Satisfaction with the Quality of Life in the Community}

In general, residents from metro and non-metro areas seemed satisfied with the quality of life in the community they currently live in (Table 4.5). About $80 \%$ of the metro respondents and about $72 \%$ of non-metro respondents said they are either very satisfied or satisfied with the quality of life in their respective communities.

Table 4.5 Satisfaction with the quality of life in the community

\begin{tabular}{|l|c|c|c|}
\hline & $\begin{array}{c}\text { Metro } \\
\text { Residents }\end{array}$ & $\begin{array}{c}\text { Non- } \\
\text { Metro } \\
\text { Residents }\end{array}$ & Overall \\
\hline Very dissatisfied & $1.4 \%$ & $2.8 \%$ & $2.2 \%$ \\
\hline Dissatisfied & $6.8 \%$ & $9.6 \%$ & $8.4 \%$ \\
\hline $\begin{array}{l}\text { Neither satisfied nor } \\
\text { dissatisfied }\end{array}$ & $10.9 \%$ & $15.3 \%$ & $13.4 \%$ \\
\hline Satisfied & $51.2 \%$ & $44.9 \%$ & $47.5 \%$ \\
\hline Very satisfied & $29.7 \%$ & $27.5 \%$ & $28.4 \%$ \\
\hline
\end{tabular}

\subsection{Quality of Each Livability Factor in Your Community}

Respondents were asked to rate the quality of each livability factor in the community they are currently living in as very poor $=1$, poor $=2$, acceptable $=3$, good $=4$, or very good $=5$.

Average ratings are shown in Table 4.6. None of the livability factors in either metro or nonmetro areas have an average score above 4 . However, the top-rated livability factors were rated good on average. In metro areas, the five factors with the highest ratings are quality 
healthcare, parks and recreation facilities, clean environment, quality public schools, and weather. The five factors with the highest ratings in non-metro areas are clean environment, traffic safety, low crime, sense of community, and quality public schools.

Table 4.6 Current quality of livability factors in your community

\begin{tabular}{|l|c|c|c|}
\hline & $\begin{array}{c}\text { Metro } \\
\text { Residents }\end{array}$ & $\begin{array}{c}\text { Non- } \\
\text { Metro } \\
\text { Residents }\end{array}$ & Overall \\
\hline Available jobs & 3.2 & 2.7 & 2.9 \\
\hline Affordable transportation options & 3.0 & 2.5 & 2.7 \\
\hline Cultural institutions & 3.2 & 2.8 & 2.9 \\
\hline Quality healthcare & 3.8 & 3.3 & 3.5 \\
\hline Affordable housing & 3.2 & 3.1 & 3.1 \\
\hline Quality public schools & 3.6 & 3.5 & 3.6 \\
\hline Overall cost of living & 3.4 & 3.3 & 3.3 \\
\hline Shopping and entertainment options & 3.3 & 2.5 & 2.9 \\
\hline Parks and recreation facilities & 3.7 & 3.4 & 3.5 \\
\hline Weather & 3.6 & 3.5 & 3.6 \\
\hline Clean environment & 3.7 & 3.8 & 3.7 \\
\hline Low crime & 3.5 & 3.7 & 3.6 \\
\hline Sense of community & 3.5 & 3.6 & 3.6 \\
\hline Traffic Safety & 3.5 & 3.8 & 3.6 \\
\hline
\end{tabular}

Note: Scale: 1 = very poor, 2 = poor, 3 = acceptable, $4=$ good, and $5=$ very good.

The quality of livability factors of the current community were mapped with importance of livability factors to identify the gaps that would help identify which factors were perceived to be important but are not in good quality in their current communities. Livability factors with larger gaps between importance and quality are identified as factors needing improvement to enhance livability for the respective communities.

Figure 4.7 illustrates mapping of livability factors' quality scale with livability factors' importance scale for metro areas. Apart from weather, no other livability factor quality reached the importance standards defined by metro residents for a general community. Further, livability factors, such as available jobs, affordable housing, low crime, and affordable transportation options, have a huge gap in their current communities when compared with optimal importance standards in a general community.

Similarly, Figure 4.8 illustrates mapping of livability factors' quality scale with livability factors' importance scale for non-metro areas. Again, apart from weather, no other livability factor quality in current communities reached the importance standards defined by the non-metro residents for a general community. Livability factors, such as available jobs, affordable housing, quality healthcare, affordable transportation options, and overall cost of living, have a huge gap in their current communities when compared with optimal importance standards in a general community. Improving these livability factors in non-metro communities can improve the 
livability of non-metro residents. While metro communities have gaps, the gaps identified for non-metro communities are much higher, meaning there is a greater need to improve these livability factors in non-metro areas compared with metro areas.

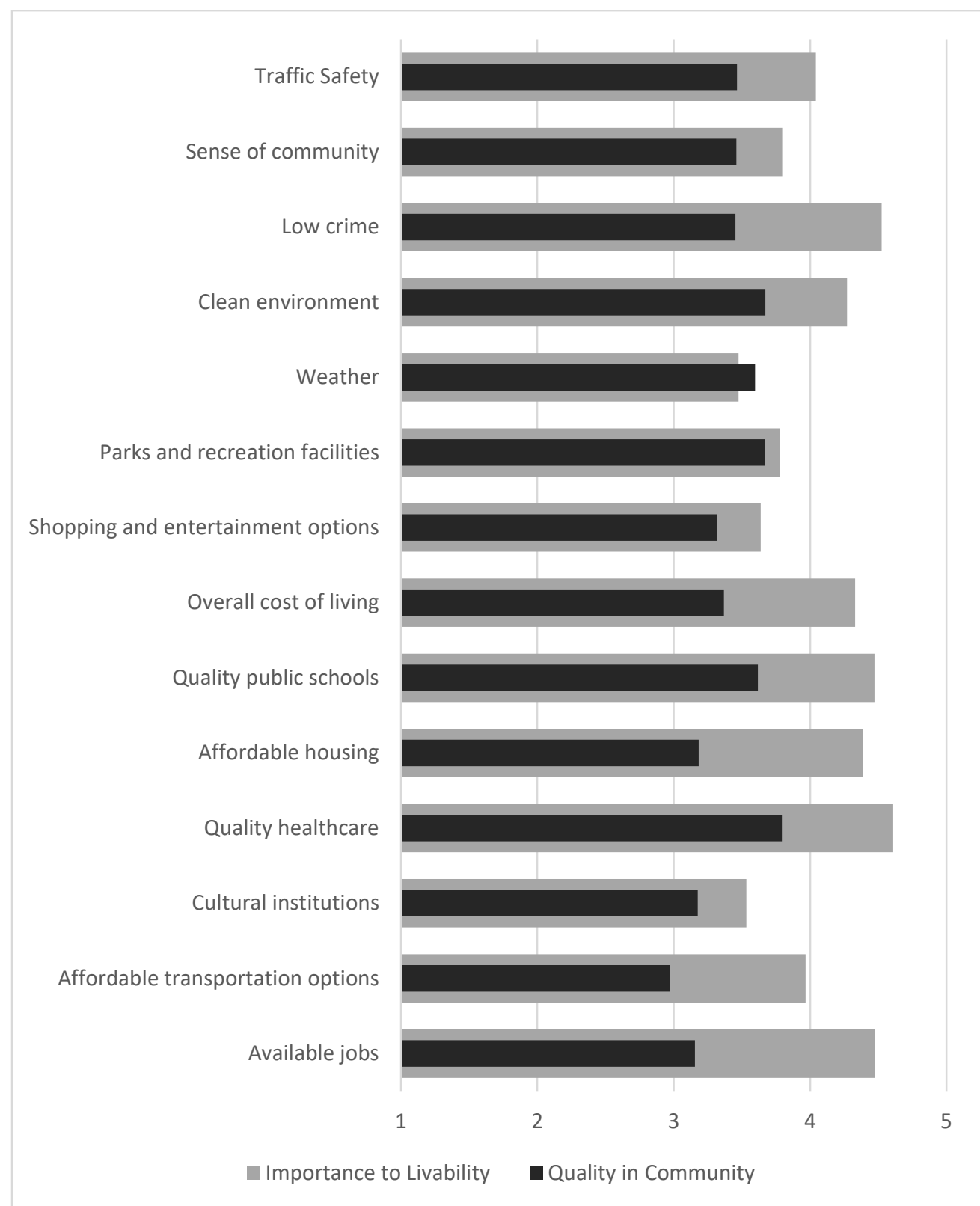

Figure 4.7 Metro Areas: Importance of livability factors in a general community vs. quality of livability factors in the current community 


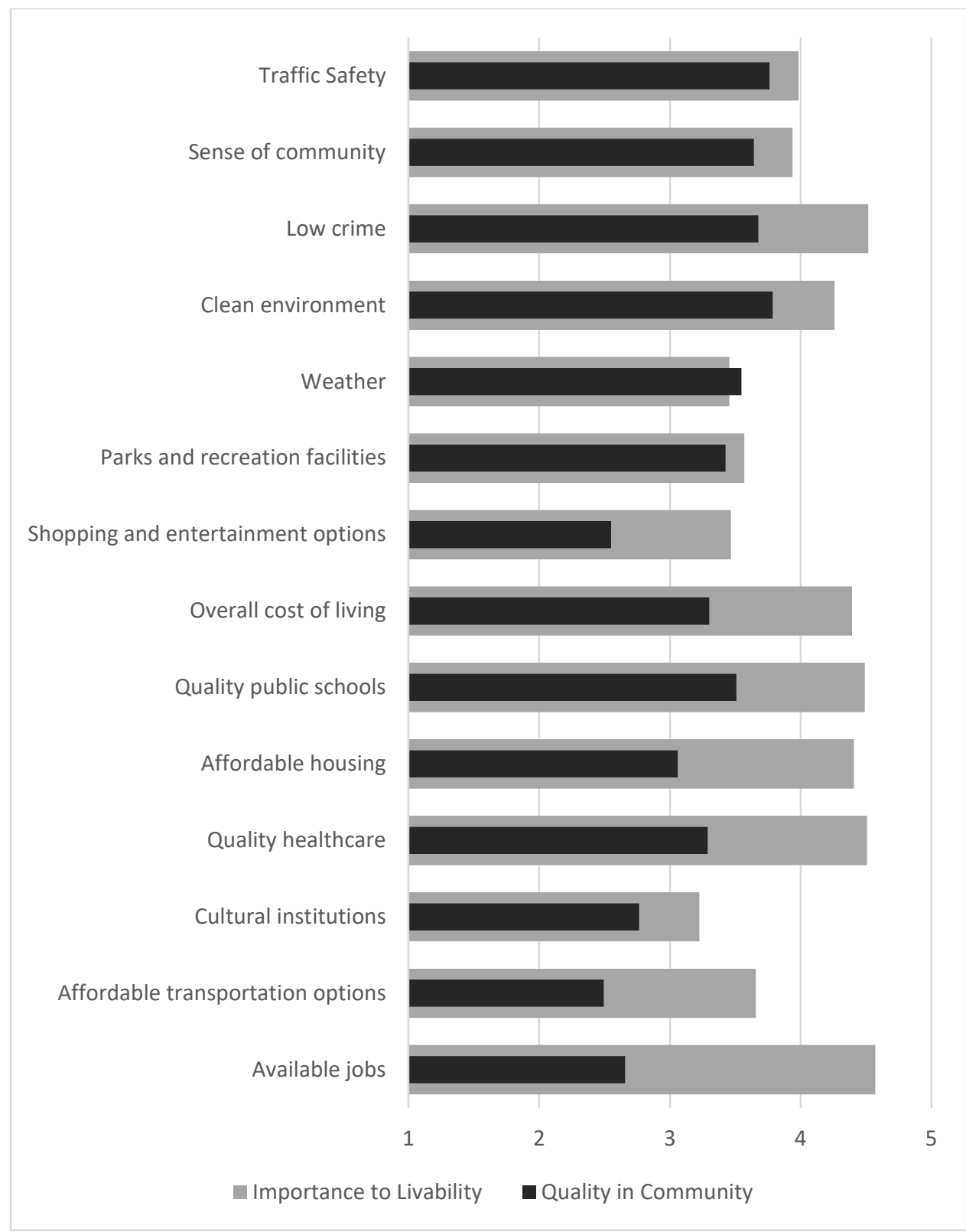

Figure 4.8 Non-metro Areas: Importance of livability factors in a general community vs. quality of livability factors in the current community

Figure 4.9 illustrates the gap (difference in numeric averages) and gap magnitude of various livability factors. Therefore, it can be summarized from these findings that increasing available jobs and affordable housing and transportation options and reducing crime in metro communities can improve the livability of metro residents. In non-metro areas, livability can be improved the most by the greater availability of jobs, affordable housing, quality healthcare, and affordable transportation options. 


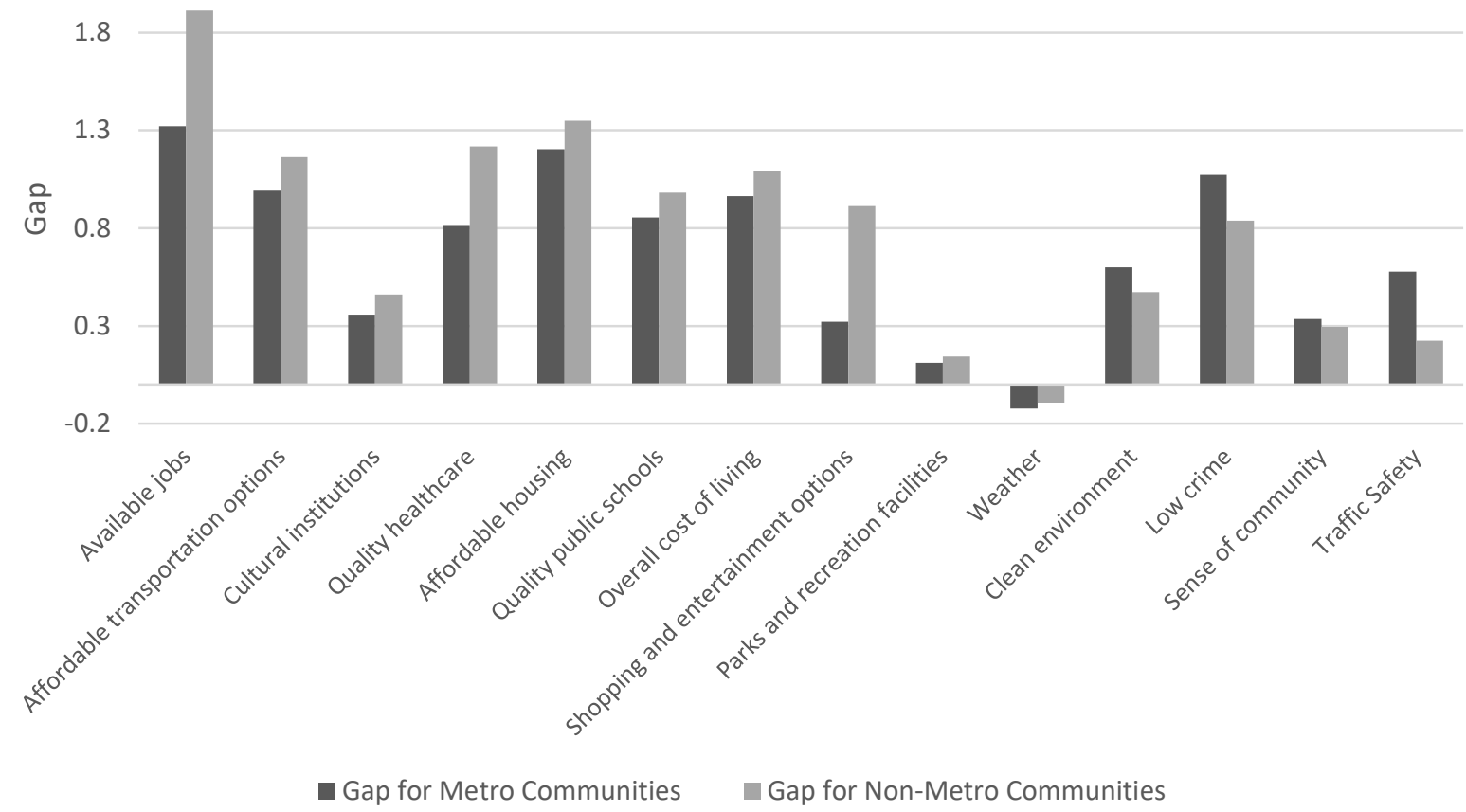

Figure 4.9 Gap between livability factors' importance in general community and quality in current communities

\subsection{Quality of Each Aspect of Transportation in Your Community}

Respondents were asked to rate the quality of different transportation aspects in the community where they are currently living using the same scale: $1=$ very poor, $2=$ poor, $3=$ acceptable, 4 = good, and 5 = very good.

Average scores are shown Table 4.7. None of the average scores are above 4. The top three aspects of transportation rated as being of better quality are low traffic congestion, walkability/accessibility, and bikeability in metro areas, and low traffic congestion, walkability/accessibility, and road conditions in non-metro areas. Note that metro residents gave similar average scores to each of the five transportation aspects considered, while average scores by non-metro residents varied more widely. While both metro and non-metro residents gave high scores for low congestion, the average rating was significantly higher for non-metro residents. Similarly, while both metro and non-metro residents gave lower scores for public transit services, the average rating was much lower for non-metro residents. 
Table 4.7 Quality of each aspect of transportation in your community currently

\begin{tabular}{|l|c|c|c|}
\hline & $\begin{array}{c}\text { Metro } \\
\text { Residents }\end{array}$ & $\begin{array}{c}\text { Non-Metro } \\
\text { Residents }\end{array}$ & Overall \\
\hline Public transit services & 2.8 & 2.2 & 2.5 \\
\hline Bikeability & 3.1 & 2.9 & 3.0 \\
\hline Low traffic congestion & 3.2 & 3.7 & 3.5 \\
\hline Walkability / accessibility & 3.2 & 3.2 & 3.2 \\
\hline Roads in good condition & 3.0 & 3.0 & 3.0 \\
\hline
\end{tabular}

The quality of various transportation aspects $(1=$ very poor, $2=$ poor, $3=$ acceptable, $4=$ good, and $5=$ very good) of the current community were mapped with importance of transportation aspects $(1=$ not important, 2 = slightly important, $3=$ moderately important, $4=$ important, and $5=$ very important) to identify gaps between importance and quality, as shown Figure 4.10. For metro communities, the gaps are greatest for road conditions, public transit services, traffic congestion, and walkability/accessibility. Similarly, for non-metro communities, gaps are greatest for road conditions, public transit services, and walkability/accessibility. Improving these aspects can improve the state of transportation and community livability.

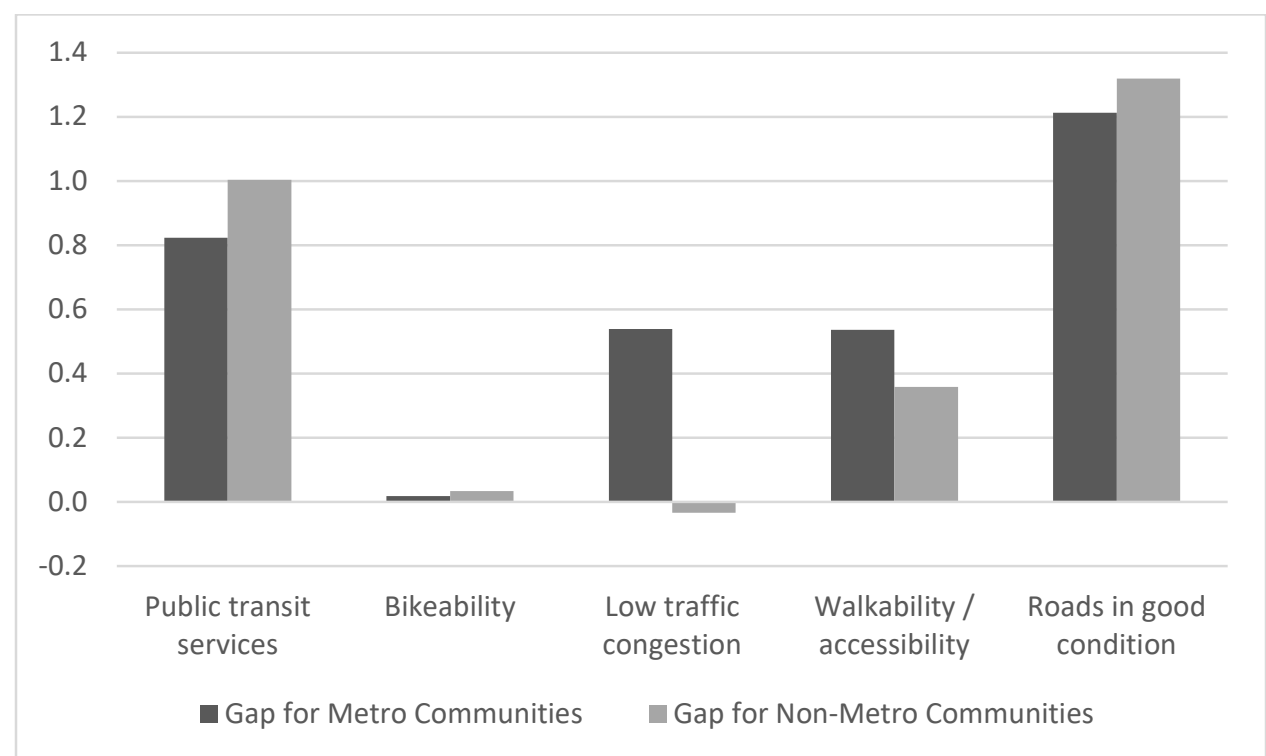

Figure 4.10 Gap between various transportation aspects' importance in general community and quality in current communities 


\subsection{Type of Streets Residents are Living On}

About $80 \%$ of non-metro residents lived either on a rural street or in open country (Table 4.8). In metro areas, a majority of the residents lived on a suburban street, followed by a rural street, in open country, and on a general urban street (Table 4.8).

Table 4.8 Which of the following most closely describes the kind of

\begin{tabular}{|l|c|c|c|}
\hline & $\begin{array}{c}\text { Metro } \\
\text { Residents }\end{array}$ & $\begin{array}{c}\text { Non-Metro } \\
\text { Residents }\end{array}$ & Overall \\
\hline Urban core street & $1.0 \%$ & $0.7 \%$ & $0.8 \%$ \\
\hline Urban center street & $3.9 \%$ & $1.4 \%$ & $2.4 \%$ \\
\hline General urban street & $11.9 \%$ & $3.5 \%$ & $7.0 \%$ \\
\hline Suburban street & $45.2 \%$ & $15.9 \%$ & $28.2 \%$ \\
\hline Rural street & $25.7 \%$ & $42.5 \%$ & $35.5 \%$ \\
\hline Open country & $12.4 \%$ & $36.0 \%$ & $26.1 \%$ \\
\hline
\end{tabular}

\subsection{Phrase That Best Describes Your Community in Terms of Geographic Size}

When asked how they define their community, the largest share of residents in metro and nonmetro areas define their city as their community (Table 4.9). However, when compared with metro areas, a significantly higher percentage of non-metro residents have a broader perspective about their community by thinking of their county and the entire region as their community; this finding falls in compliance with sense of community, which is observed as one of the top five livability factors identified in non-metro areas (Section 4.4, and Table 4.6).

Table 4.9 What phrase best describes the way you define your community in terms of geographic size?

\begin{tabular}{|l|c|c|c|}
\hline & $\begin{array}{c}\text { Metro } \\
\text { Residents }\end{array}$ & $\begin{array}{c}\text { Non- } \\
\text { Metro } \\
\text { Residents }\end{array}$ & Overall \\
\hline $\begin{array}{l}\text { My community is a part of my local } \\
\text { neighborhood }\end{array}$ & $16.8 \%$ & $11.6 \%$ & $13.8 \%$ \\
\hline $\begin{array}{l}\text { My community is my whole local } \\
\text { neighborhood }\end{array}$ & $17.3 \%$ & $11.1 \%$ & $13.7 \%$ \\
\hline My community is my city & $29.5 \%$ & $27.0 \%$ & $28.1 \%$ \\
\hline My community is my county & $13.7 \%$ & $22.7 \%$ & $18.9 \%$ \\
\hline My community is all of the region I live in & $18.7 \%$ & $21.3 \%$ & $20.2 \%$ \\
\hline Other & $2.6 \%$ & $4.7 \%$ & $3.8 \%$ \\
\hline
\end{tabular}




\subsection{Can Easily Travel to Places I Need to Go in My Community Using My Current Travel Options}

A majority (more than $80 \%$ ) of respondents from both metro and non-metro areas either agree or strongly agree that they can easily travel to places they need to go in their respective communities using their current travel options (Table 4.10). While a very small percentage of respondents disagree or strongly disagree with the above statement, these percentages are comparatively higher for non-metro residents compared with metro residents, suggesting there are some non-metro residents who have mobility challenges traveling to places using current travel options. In general, transportation options in rural non-metro communities are limited; therefore, there is a need to provide more transportation options.

Table 4.10 How much do you agree or disagree with the following statement? "I can easily travel to places I need to go in my community using my current travel options."

\begin{tabular}{|l|c|c|c|}
\hline & $\begin{array}{c}\text { Metro } \\
\text { Residents }\end{array}$ & $\begin{array}{c}\text { Non-Metro } \\
\text { Residents }\end{array}$ & Overall \\
\hline Strongly disagree & $1.9 \%$ & $4.0 \%$ & $3.1 \%$ \\
\hline Disagree & $2.9 \%$ & $3.5 \%$ & $3.2 \%$ \\
\hline Neutral & $8.4 \%$ & $7.5 \%$ & $7.8 \%$ \\
\hline Agree & $43.4 \%$ & $43.7 \%$ & $43.6 \%$ \\
\hline Strongly agree & $39.6 \%$ & $38.5 \%$ & $38.9 \%$ \\
\hline
\end{tabular}

\subsection{How Many Days Do You Use Each Mode in a Typical Week?}

Respondents were asked how often they use various modes of transportation in a typical week. Responses by metro and non-metro residents were more or less the same, with a majority of respondents mentioning "drive myself" as their travel mode for five or more days (Table 4.11). Walking was found to be the next most used mode choice, followed by personal bicycling, although the percentages of respondents for these mode choices are much smaller when compared with the "drive myself" option. Further, comparatively more metro respondents preferred diverse modes of transportation choices, such as bike share, carpool, ride-sourcing, and car sharing. One most probable explanation for diverse transportation choice options among metro residents could be the availability of diverse transportation choices. This statement is also evident from the fact that comparatively more non-metro respondents mentioned "not applicable" as an option for these diverse transportation mode choices.

When compared with non-metro areas, a higher percentage of metro respondents use public transit for any number of days in a week. Lower public transit ridership among non-metro respondents could be because the coverage and service frequency of transit may be comparatively lower than in metro areas. This is also evident from the fact that almost $45 \%$ of non-metro respondents mentioned "not applicable" as their response for public transit mode 
choice, which could either mean they do not have an operational transit service or they were not aware of an operational transit service. Refer to Table 4.11 for a detailed summary of transportation mode choices and frequency of usage for metro and non-metro residents.

Table 4.11 How many days do you use each mode in a typical week?

Metro Residents

\begin{tabular}{|c|c|c|c|c|c|}
\hline & NA & 0 days & 1 day & 2-4 days & 5 or more days \\
\hline Walk & $7.4 \%$ & $43.2 \%$ & $15.8 \%$ & $16.5 \%$ & $12.7 \%$ \\
\hline Personal bicycle & $18.2 \%$ & $61.6 \%$ & $8.2 \%$ & $5.5 \%$ & $1.2 \%$ \\
\hline Bike share & $37.6 \%$ & $54.9 \%$ & $1.2 \%$ & $0.5 \%$ & $0.5 \%$ \\
\hline Drive myself & $2.6 \%$ & $3.1 \%$ & $4.3 \%$ & $17.7 \%$ & $70.3 \%$ \\
\hline Carpool & $13.9 \%$ & $64.0 \%$ & $8.4 \%$ & $5.3 \%$ & $3.4 \%$ \\
\hline Public transit & $21.3 \%$ & $60.9 \%$ & $5.5 \%$ & $4.6 \%$ & $3.1 \%$ \\
\hline Vanpool & $22.8 \%$ & $71.0 \%$ & $1.0 \%$ & $0.2 \%$ & $0.5 \%$ \\
\hline Taxi-cab & $14.6 \%$ & $78.7 \%$ & $1.4 \%$ & $1.4 \%$ & $0.0 \%$ \\
\hline Ride-sourcing & $17.3 \%$ & $72.9 \%$ & $4.6 \%$ & $0.7 \%$ & $0.2 \%$ \\
\hline Car-share & $25.9 \%$ & $68.1 \%$ & $1.4 \%$ & $0.2 \%$ & $0.0 \%$ \\
\hline \multicolumn{6}{|c|}{ Non-metro Residents } \\
\hline & NA & 0 days & 1 day & 2-4 days & 5 or more days \\
\hline Walk & $7.3 \%$ & $47.5 \%$ & $12.3 \%$ & $15.4 \%$ & $\square \quad 11.6 \%$ \\
\hline Personal bicycle & $18.2 \%$ & $62.9 \%$ & $7.5 \%$ & $5.0 \%$ & $1.6 \%$ \\
\hline Bike share & $46.8 \%$ & $45.6 \%$ & $0.3 \%$ & $0.0 \%$ & $0.3 \%$ \\
\hline Drive myself & $2.8 \%$ & $2.9 \%$ & $3.8 \%$ & $18.9 \%$ & $70.0 \%$ \\
\hline Carpool & $26.3 \%$ & $54.8 \%$ & $5.9 \%$ & $5.7 \%$ & $2.4 \%$ \\
\hline Public transit & $44.5 \%$ & $47.8 \%$ & $1.9 \%$ & $1.2 \%$ & $0.3 \%$ \\
\hline Vanpool & $45.6 \%$ & $48.5 \%$ & $1.2 \%$ & $0.7 \%$ & $0.3 \%$ \\
\hline Taxi-cab & $40.9 \%$ & $54.6 \%$ & $0.0 \%$ & $0.2 \%$ & $0.3 \%$ \\
\hline Ride-sourcing & $55.5 \%$ & $40.0 \%$ & $0.5 \%$ & $0.0 \%$ & $0.2 \%$ \\
\hline Car-share & $56.8 \%$ & $38.1 \%$ & $0.9 \%$ & $0.3 \%$ & $0.0 \%$ \\
\hline \multicolumn{6}{|c|}{ Overall } \\
\hline & NA & 0 days & 1 day & 2-4 days & 5 or more days \\
\hline Walk & $7.3 \%$ & $45.7 \%$ & $13.8 \%$ & $15.9 \%$ & $12.1 \%$ \\
\hline Personal bicycle & $18.2 \%$ & $62.4 \%$ & $7.7 \%$ & $5.2 \%$ & $1.4 \%$ \\
\hline Bike share & $43.0 \%$ & $49.5 \%$ & $0.7 \%$ & $0.2 \%$ & $0.4 \%$ \\
\hline Drive myself & $2.7 \%$ & $3.0 \%$ & $4.0 \%$ & $18.4 \%$ & $70.1 \%$ \\
\hline Carpool & $21.1 \%$ & $58.7 \%$ & $6.9 \%$ & $5.5 \%$ & $2.8 \%$ \\
\hline Public transit & $34.8 \%$ & $53.3 \%$ & $3.4 \%$ & $2.6 \%$ & $1.5 \%$ \\
\hline Vanpool & $36.0 \%$ & $57.9 \%$ & $1.1 \%$ & $0.5 \%$ & $0.4 \%$ \\
\hline Taxi-cab & $29.9 \%$ & $64.7 \%$ & $0.6 \%$ & $0.7 \%$ & $0.2 \%$ \\
\hline Ride-sourcing & $39.4 \%$ & $53.8 \%$ & $2.2 \%$ & $0.3 \%$ & $0.2 \%$ \\
\hline Car-share & $43.9 \%$ & $50.7 \%$ & $1.1 \%$ & $0.3 \%$ & $0.0 \%$ \\
\hline
\end{tabular}

Note: NA: Not Available or Not Applicable 


\subsection{Public Transit}

When asked about the availability of public transit to the residents of their community, $68.3 \%$ of metro respondents and $43.5 \%$ of non-metro respondents mentioned that public transit is available (Figure 4.11). According to resident respondents, availability of public transit is comparatively less in non-metro communities. It is also interesting to find that only a small percentage of respondents in both metro and non-metro areas are unaware of public transit availability in their community. Metro respondents were found to use public transit three times more than non-metro respondents; further, a comparatively higher percentage of metro respondents knew someone else who has used public transit (Figure 4.11).

Respondents who do not have transit in their community were asked if they would use it if it were available. Interestingly, a significantly higher percentage of non-metro residents who lack transit said they would be likely to use it, as compared with metro-residents who lack access. This observation could explain that less public transit usage in non-metro areas could be attributed to lack of proper transit services and facilities in rural non-metro areas.

According to community respondents, local bus transit service is the most available transit service in both metro and non-metro communities, followed by paratransit service (Figure 4.11). However, it must be noted that availability of these two kinds of services in non-metro areas is only about half when compared with metro-areas. Availability of demand response service is about the same in both metro and non-metro areas. Transit services, such as commuter bus, rail, and intercity bus, are more popular and available in metro areas when compared with rural areas (Figure 4.11). 

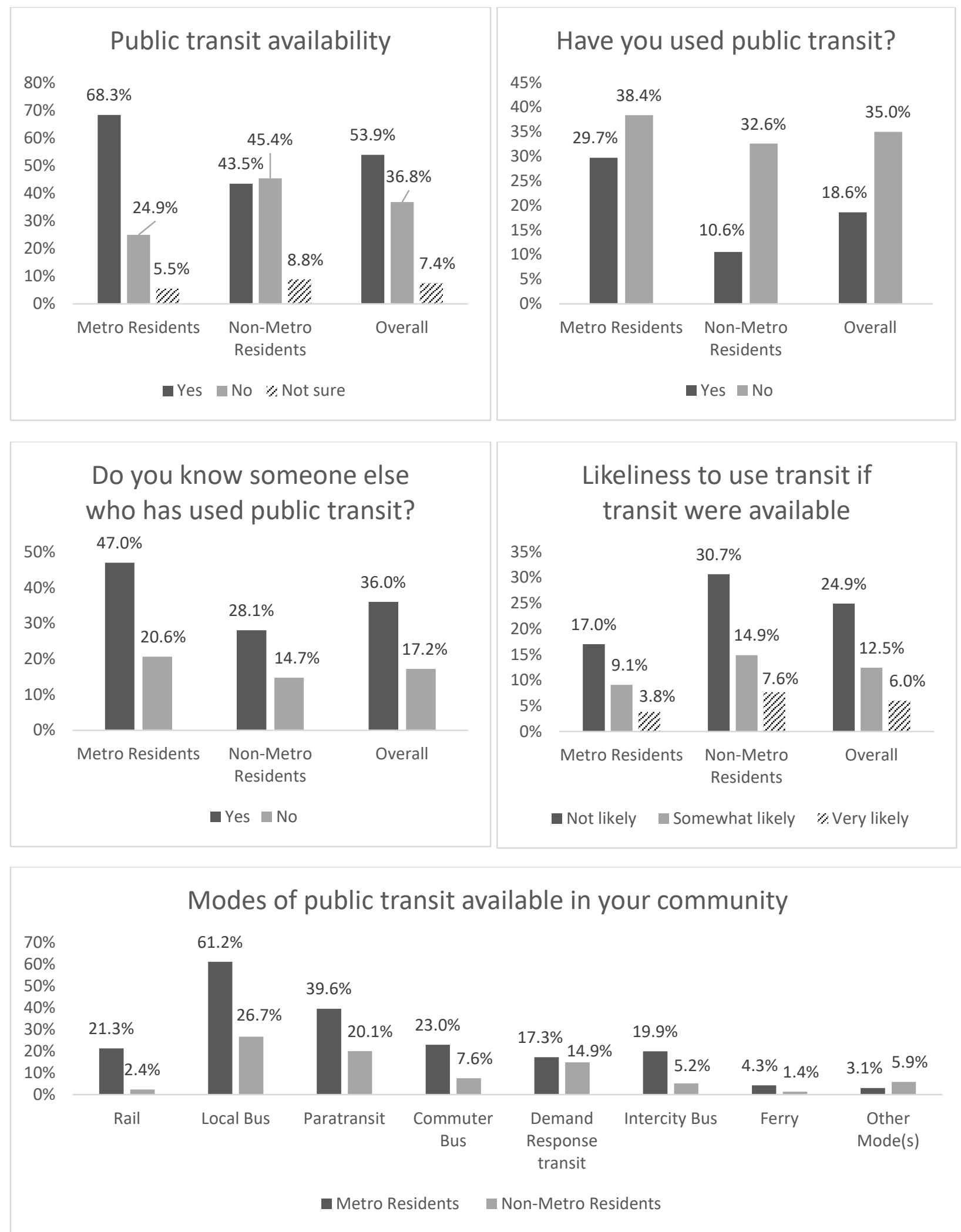

Figure 4.11 Public transit availability, usage, and interest 
More than half of metro respondents mentioned that public transit is accessible to make trips from their residence to various types of destinations, such as grocery stores/super markets, personal services, other retail shopping, recreation and entertainment, and healthcare facilities (Table 4.12). Among non-metro respondents, accessibility of public transit services from an individual's residence to various types of destinations is lower when compared with metro areas.

Table 4.12 If you chose to, could you ride public transit from near your residence to the following types of places?

\begin{tabular}{|l|c|c|c|c|c|c|}
\hline \multirow{2}{*}{} & \multicolumn{2}{|c|}{ Yes } & \multicolumn{2}{c|}{ No } & \multicolumn{2}{c|}{ Not sure } \\
\cline { 2 - 7 } & $\begin{array}{c}\text { Metro } \\
\text { Residents }\end{array}$ & $\begin{array}{c}\text { Non-Metro } \\
\text { Residents }\end{array}$ & $\begin{array}{c}\text { Metro } \\
\text { Residents }\end{array}$ & $\begin{array}{c}\text { Non-Metro } \\
\text { Residents }\end{array}$ & $\begin{array}{c}\text { Metro } \\
\text { Residents }\end{array}$ & $\begin{array}{c}\text { Non-Metro } \\
\text { Residents }\end{array}$ \\
\hline Grocery store or supermarket & $60.5 \%$ & $60.1 \%$ & $26.1 \%$ & $30.3 \%$ & $13.4 \%$ & $9.7 \%$ \\
\hline Personal services & $57.6 \%$ & $53.8 \%$ & $26.8 \%$ & $33.2 \%$ & $15.6 \%$ & $12.2 \%$ \\
\hline Other retail shopping & $62.3 \%$ & $56.3 \%$ & $24.3 \%$ & $31.1 \%$ & $13.0 \%$ & $12.2 \%$ \\
\hline Recreation and Entertainment & $54.3 \%$ & $42.4 \%$ & $26.4 \%$ & $37.0 \%$ & $18.8 \%$ & $19.3 \%$ \\
\hline Health care facility & $60.1 \%$ & $60.1 \%$ & $25.4 \%$ & $27.7 \%$ & $14.5 \%$ & $11.3 \%$ \\
\hline
\end{tabular}

A grocery store or supermarket is the most accessible destination by walking (if the respondent is able and chooses to walk) for metro and non-metro respondents in their respective communities, although the accessibility rate is lower for non-metro areas when compared with metro areas (Table 4.13). The next most accessible destinations, in order of accessibility, are personal services, other retail shopping, recreation and entertainment, and healthcare. Again, all these destinations are less accessible in non-metro areas when compared with metro areas. It was observed from Table 4.13 that healthcare facilities are the least accessible destinations by walking in both metro and non-metro areas.

Table 4.13 If you are able, and chose to, could you walk from your residence to the following types of places?

\begin{tabular}{|l|c|c|c|c|c|c|}
\hline \multirow{2}{*}{} & \multicolumn{2}{|c|}{ Yes } & \multicolumn{2}{c|}{ No } & \multicolumn{2}{c|}{ Not sure } \\
\cline { 2 - 7 } & $\begin{array}{c}\text { Metro } \\
\text { Residents }\end{array}$ & $\begin{array}{c}\text { Non-Metro } \\
\text { Residents }\end{array}$ & $\begin{array}{c}\text { Metro } \\
\text { Residents }\end{array}$ & $\begin{array}{c}\text { Non-Metro } \\
\text { Residents }\end{array}$ & $\begin{array}{c}\text { Metro } \\
\text { Residents }\end{array}$ & $\begin{array}{c}\text { Non-Metro } \\
\text { Residents }\end{array}$ \\
\hline Grocery store or supermarket & $53.5 \%$ & $38.0 \%$ & $44.8 \%$ & $58.8 \%$ & $0.7 \%$ & $2.1 \%$ \\
\hline Personal services & $49.2 \%$ & $35.9 \%$ & $48.2 \%$ & $60.8 \%$ & $1.9 \%$ & $1.6 \%$ \\
\hline Other retail shopping & $41.5 \%$ & $27.9 \%$ & $54.7 \%$ & $67.8 \%$ & $2.6 \%$ & $2.6 \%$ \\
\hline Recreation and Entertainment & $39.6 \%$ & $31.0 \%$ & $56.4 \%$ & $65.0 \%$ & $2.6 \%$ & $2.4 \%$ \\
\hline Health care facility & $30.7 \%$ & $26.9 \%$ & $65.9 \%$ & $69.0 \%$ & $2.2 \%$ & $2.6 \%$ \\
\hline
\end{tabular}

A majority of respondents from both metro and non-metro communities agree or strongly agree that it is important for public transit to be available to their community residents (Figure 4.12). The top five reasons for the importance of public transit in metro communities in the order of ranking are: 1) transit is an option for seniors or people with disabilities, 2) transit is an option for those who choose not to drive, 3) transit reduces traffic congestion, 4) transit is an option for saving on the cost of transportation, and 5) transit reduces energy consumption or 
protects air quality (Table 4.14). The top five reasons for the importance of public transit in non-metro communities in the order of ranking are: 1 ) transit is an option for seniors or people with disabilities, 2) transit is an option for those who choose not to drive, 3) because walk access to destinations is difficult in my community, 4) transit is an option for saving on the cost of transportation, and 5) transit reduces energy consumption or protects air quality (Table 4.14).

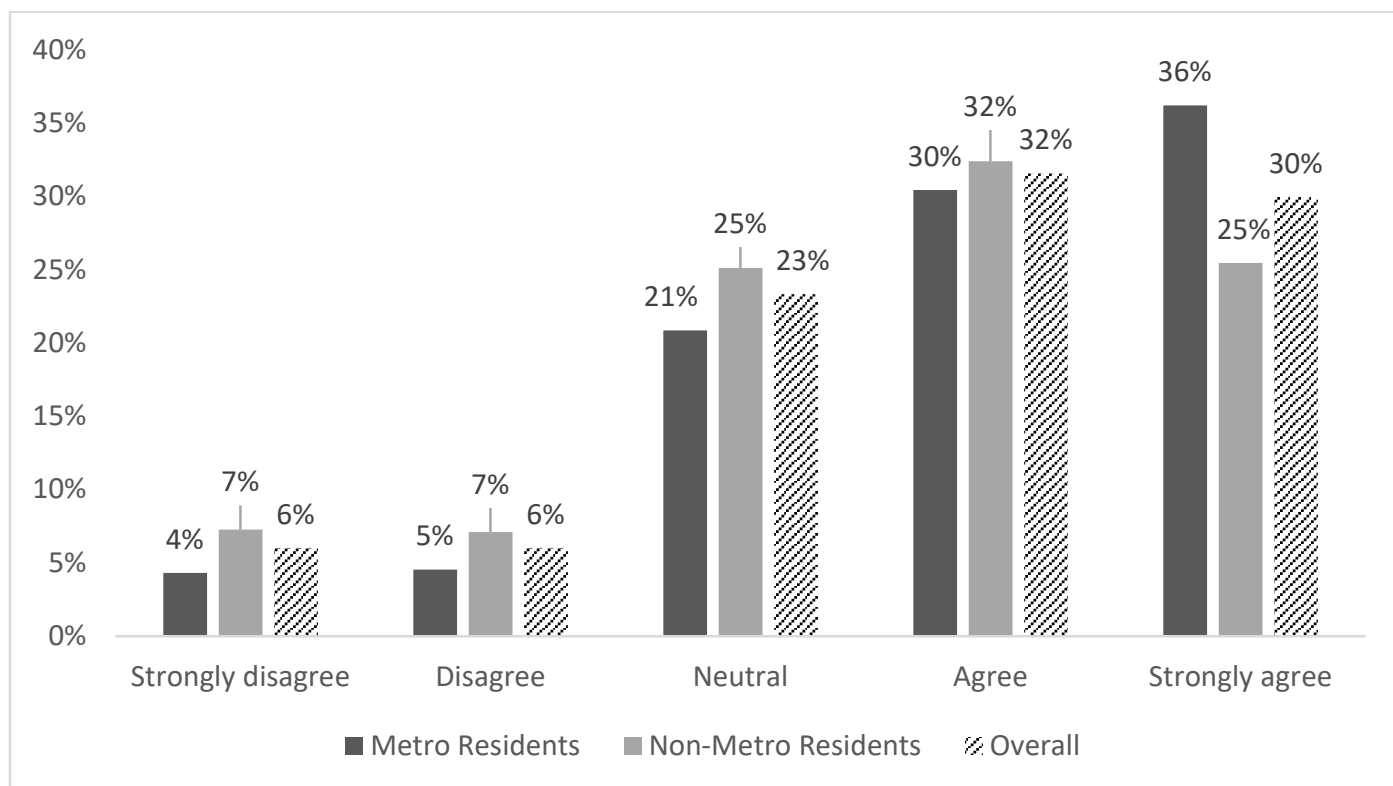

Figure 4.12 How much do you agree or disagree with the following statement? "It is important for public transit to be available to my community's residents."

Table 4.14 Why is it important to have public transit service in your community?

\begin{tabular}{|c|c|c|c|}
\hline & $\begin{array}{c}\text { Metro } \\
\text { Residents }\end{array}$ & $\begin{array}{l}\text { Non-Metro } \\
\text { Residents }\end{array}$ & Overall \\
\hline Because walk access to destinations is difficult in my community & $42.7 \%$ & $42.8 \%$ & $42.8 \%$ \\
\hline Because bike access to destinations is difficult in my community & $26.1 \%$ & $27.4 \%$ & $26.9 \%$ \\
\hline Transit is an option for seniors or people with disabilities & $73.4 \%$ & $75.6 \%$ & $74.6 \%$ \\
\hline Transit is an option for those who choose not to drive & $71.0 \%$ & $57.2 \%$ & $63.0 \%$ \\
\hline Transit is an option for saving on the cost of transportation & $53.0 \%$ & $38.6 \%$ & $44.7 \%$ \\
\hline Transit complements other travel modes, such as walking or biking & $46.5 \%$ & $30.5 \%$ & $37.2 \%$ \\
\hline Transit reduces energy consumption or protects air quality & $48.2 \%$ & $36.6 \%$ & $41.4 \%$ \\
\hline Transit eliminates the need to park or for destinations to provide parking & $42.0 \%$ & $26.2 \%$ & $32.8 \%$ \\
\hline Transit reduces traffic congestion & $53.2 \%$ & $32.9 \%$ & $41.4 \%$ \\
\hline I do not think it is important to have transit service & $7.9 \%$ & $13.0 \%$ & $10.9 \%$ \\
\hline
\end{tabular}

In most cases a majority of the metro and non-metro respondents either agree or strongly agree with funding transit using city, county, state, or federal funds (Table 4.15). However, for all funding types, metro-area respondents were more likely than their non-metro counterparts to support using public funds for transit. Most respondents in metro and non-metro areas either support the same amount of public transit currently in place or more public transit in 
their communities (Figure 4.13). Most also believe that some $(<50 \%)$ or most $(>50 \%)$ of transit operation costs should come from transit fares (Figure 4.14).

Most metro and non-metro respondents believe that some individuals should be eligible for a reduced fare. In order of priority, they support reduced fare for people with disabilities, lowincome individuals, military veterans, Medicare or Medicaid cardholders, K-12 students, and college/university students (Table 4.16). A majority of respondents mentioned that they would begin using transit or use transit more often under two potential circumstances: if they are no longer able to drive for health reasons or if they move to a more urban community with transit (Table 4.17).

Table 4.15 How much do you agree with the following statements about funding transit?

\begin{tabular}{|c|c|c|c|c|c|c|}
\hline & & $\begin{array}{l}\text { Strongly } \\
\text { disagree }\end{array}$ & Disagree & Neutral & Agree & $\begin{array}{l}\text { Strongly } \\
\text { agree }\end{array}$ \\
\hline \multirow{3}{*}{$\begin{array}{l}\text { I support using city funds for } \\
\text { transit }\end{array}$} & Metro Residents & $7.0 \%$ & $7.4 \%$ & $24.7 \%$ & $36.7 \%$ & $20.9 \%$ \\
\hline & Non-Metro Residents & $12.1 \%$ & $9.2 \%$ & $26.5 \%$ & $33.3 \%$ & $14.0 \%$ \\
\hline & Overall & $10.0 \%$ & $8.5 \%$ & $25.8 \%$ & $34.7 \%$ & $16.9 \%$ \\
\hline \multirow{3}{*}{$\begin{array}{l}\text { I support using county (or county } \\
\text { equivalent) funds for transit }\end{array}$} & Metro Residents & $5.5 \%$ & $8.4 \%$ & $25.9 \%$ & $36.9 \%$ & $19.9 \%$ \\
\hline & Non-Metro Residents & $12.7 \%$ & $8.5 \%$ & $26.2 \%$ & $33.8 \%$ & $15.6 \%$ \\
\hline & Overall & $9.7 \%$ & $8.5 \%$ & $26.1 \%$ & $35.1 \%$ & $17.4 \%$ \\
\hline \multirow{3}{*}{$\begin{array}{l}\text { I support using state funds for } \\
\text { transit }\end{array}$} & Metro Residents & $5.8 \%$ & $7.9 \%$ & $19.7 \%$ & $37.2 \%$ & $26.4 \%$ \\
\hline & Non-Metro Residents & $10.7 \%$ & $8.8 \%$ & $21.0 \%$ & $36.4 \%$ & $18.9 \%$ \\
\hline & Overall & $8.7 \%$ & $8.5 \%$ & $20.4 \%$ & $36.7 \%$ & $22.0 \%$ \\
\hline \multirow{3}{*}{$\begin{array}{l}\text { I support using federal funds for } \\
\text { transit }\end{array}$} & Metro Residents & $6.5 \%$ & $11.3 \%$ & $19.7 \%$ & $32.1 \%$ & $27.3 \%$ \\
\hline & Non-Metro Residents & $12.5 \%$ & $9.2 \%$ & $22.0 \%$ & $32.2 \%$ & $19.4 \%$ \\
\hline & Overall & $10.0 \%$ & $10.1 \%$ & $21.0 \%$ & $32.2 \%$ & $22.7 \%$ \\
\hline
\end{tabular}

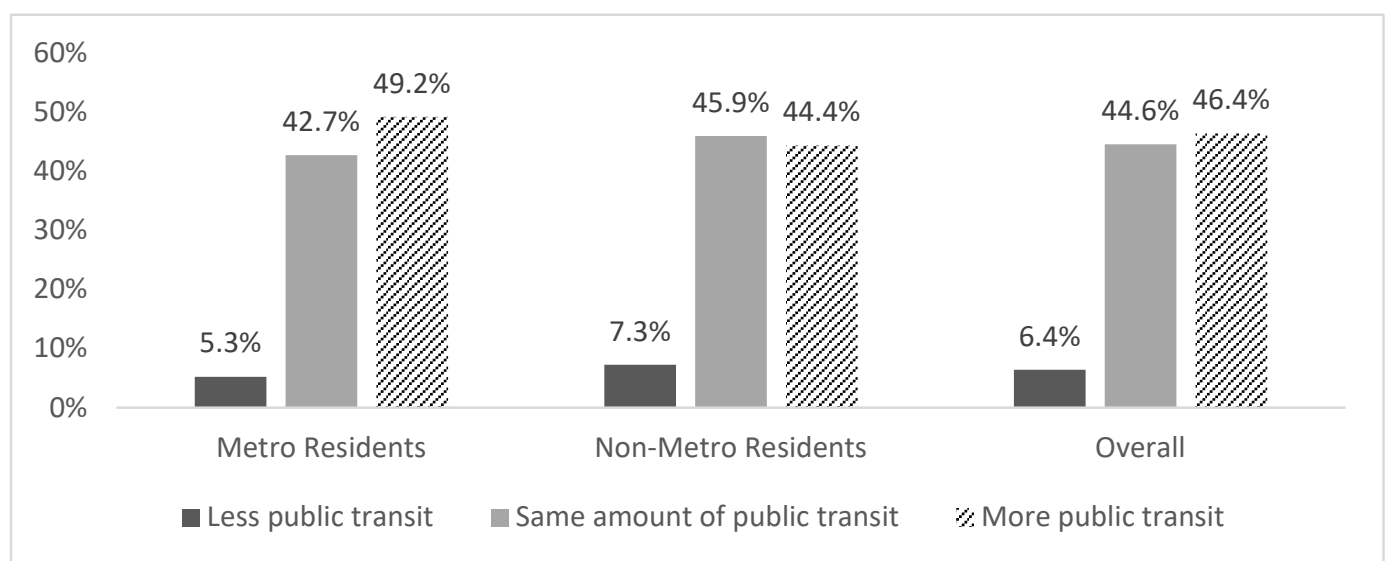

Figure 4.13 Do you support more transit, less transit, or the same amount of transit in your community, given that public funds are needed to support part of the cost? 


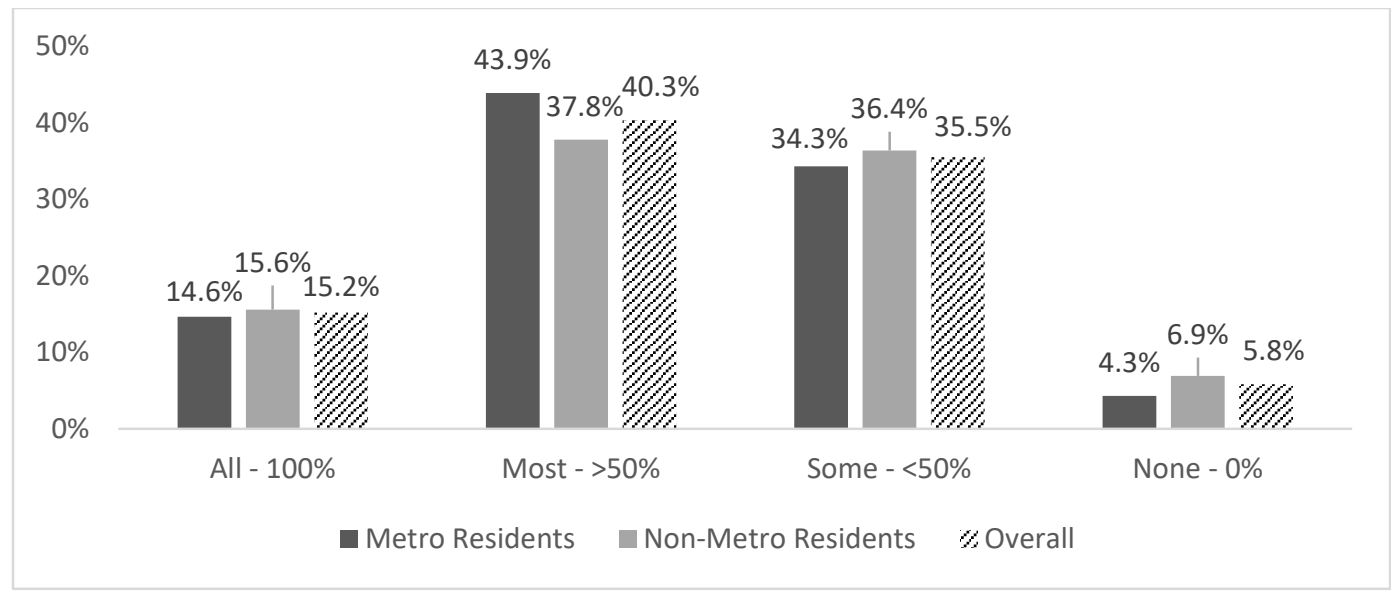

Figure 4.14 In general, how much of the total operating cost of transit should come from rider fares?

Table 4.16 Some transit riders pay a reduced fare. Who should be eligible for a reduced fare?

\begin{tabular}{|l|c|c|c|} 
& $\begin{array}{c}\text { Metro } \\
\text { Residents }\end{array}$ & $\begin{array}{c}\text { Non-Metro } \\
\text { Residents }\end{array}$ & Overall \\
\hline Military veterans & $64.0 \%$ & $63.4 \%$ & $63.7 \%$ \\
\hline People with disabilities & $83.7 \%$ & $83.2 \%$ & $83.4 \%$ \\
\hline College/university students & $51.3 \%$ & $40.0 \%$ & $44.8 \%$ \\
\hline K-12 students & $48.9 \%$ & $46.1 \%$ & $47.3 \%$ \\
\hline Medicare or Medicaid cardholders & $59.2 \%$ & $57.5 \%$ & $58.2 \%$ \\
\hline Low-income individuals & $64.7 \%$ & $63.6 \%$ & $64.1 \%$ \\
\hline Other & $10.1 \%$ & $10.1 \%$ & $10.1 \%$ \\
\hline
\end{tabular}


Table 4.17 How would the following statements change your use of transit?

\begin{tabular}{|c|c|c|c|c|c|c|}
\hline & & $\begin{array}{l}\text { Stop using } \\
\text { transit }\end{array}$ & $\begin{array}{l}\text { Use transit } \\
\text { less often }\end{array}$ & No change & $\begin{array}{l}\text { Use transit } \\
\text { more often }\end{array}$ & $\begin{array}{l}\text { Begin using } \\
\text { transit }\end{array}$ \\
\hline \multirow{3}{*}{$\begin{array}{l}\text { Fuel prices increase to over } \$ 4.00 \\
\text { per gallon }\end{array}$} & Metro Residents & $1.7 \%$ & $1.4 \%$ & $55.9 \%$ & $24.5 \%$ & $11.0 \%$ \\
\hline & Non-Metro Residents & $2.6 \%$ & $1.7 \%$ & $56.0 \%$ & $17.5 \%$ & $17.3 \%$ \\
\hline & Overall & $2.2 \%$ & $1.6 \%$ & $55.9 \%$ & $20.4 \%$ & $14.7 \%$ \\
\hline \multirow{3}{*}{$\begin{array}{l}\text { Your car breaks down or is needed } \\
\text { by someone else }\end{array}$} & Metro Residents & $0.2 \%$ & $1.4 \%$ & $42.4 \%$ & $31.2 \%$ & $18.9 \%$ \\
\hline & Non-Metro Residents & $0.3 \%$ & $1.0 \%$ & $46.3 \%$ & $23.2 \%$ & $23.6 \%$ \\
\hline & Overall & $0.3 \%$ & $1.2 \%$ & $44.7 \%$ & $26.6 \%$ & $21.6 \%$ \\
\hline \multirow{3}{*}{$\begin{array}{l}\text { Your household's income } \\
\text { decreases significantly }\end{array}$} & Metro Residents & $1.9 \%$ & $2.9 \%$ & $47.2 \%$ & $25.7 \%$ & $16.1 \%$ \\
\hline & Non-Metro Residents & $1.6 \%$ & $2.4 \%$ & $47.8 \%$ & $21.0 \%$ & $21.3 \%$ \\
\hline & Overall & $1.7 \%$ & $2.6 \%$ & $47.6 \%$ & $22.9 \%$ & $19.1 \%$ \\
\hline \multirow{3}{*}{$\begin{array}{l}\text { You are no longer able to drive for } \\
\text { health reasons }\end{array}$} & Metro Residents & $0.7 \%$ & $1.4 \%$ & $18.7 \%$ & $36.7 \%$ & $37.4 \%$ \\
\hline & Non-Metro Residents & $0.5 \%$ & $0.5 \%$ & $20.3 \%$ & $31.9 \%$ & $41.6 \%$ \\
\hline & Overall & $0.6 \%$ & $0.9 \%$ & $19.6 \%$ & $33.9 \%$ & $39.8 \%$ \\
\hline \multirow{3}{*}{$\begin{array}{l}\text { You move to a more urban } \\
\text { community with transit }\end{array}$} & Metro Residents & $0.7 \%$ & $1.7 \%$ & $23.3 \%$ & $38.8 \%$ & $30.0 \%$ \\
\hline & \begin{tabular}{|l|} 
Non-Metro Residents \\
\end{tabular} & $0.5 \%$ & $0.7 \%$ & $26.9 \%$ & $34.1 \%$ & $30.8 \%$ \\
\hline & Overall & $0.6 \%$ & $1.1 \%$ & $25.4 \%$ & $36.1 \%$ & $30.5 \%$ \\
\hline \multirow{3}{*}{$\begin{array}{l}\text { You move to a more rural } \\
\text { community with transit }\end{array}$} & Metro Residents & $2.2 \%$ & $7.2 \%$ & $46.3 \%$ & $23.0 \%$ & $15.8 \%$ \\
\hline & Non-Metro Residents & $1.0 \%$ & $3.6 \%$ & $46.8 \%$ & $22.7 \%$ & $18.7 \%$ \\
\hline & Overall & $1.5 \%$ & $5.1 \%$ & $46.6 \%$ & $22.8 \%$ & $17.5 \%$ \\
\hline
\end{tabular}

\subsection{Technology in Transportation}

Respondents were asked if they would be more willing to permanently give up their vehicle or their smartphone. Most metro (75\%) and non-metro (87.5\%) respondents chose their smartphone instead of their vehicle. While the percentage is low, comparatively more metro respondents ( $22.3 \%$ metro vs. $10.2 \%$ non-metro) were willing to give up their vehicles for smartphones.

Respondents were introduced to a possible hypothetical future situation: "In the future, you may not need to own a vehicle to have access to a vehicle when needed. For example, you may be able to join a subscription-based car-sharing service or use another mobility service of some type." Under this hypothetical situation, respondents were asked about their potential future vehicle ownership scenarios. The results are summarized in Table 4.18. While more than half of respondents from metro and non-metro communities answered that they would always choose to own their own vehicles, it is interesting to observe that some percentage of respondents from metro and non-metro communities choose to no longer own a vehicle, some within the next 10 years, and others in the more distant future (Table 4.18).

In the context of the potential existence of self-driving vehicles (autonomous vehicles) in the future, respondents were asked to provide their level of comfort with the idea of an autonomous vehicle picking up and dropping them off for a personal business appointment. While close to half of respondents (from both metro and non-metro communities) answered they would be uncomfortable, about a quarter responded they would be either comfortable or very comfortable (Table 4.19). 
Table 4.18 Which of the following statements most likely describes your future vehicle ownership?

\begin{tabular}{|l|r|r|r|}
\hline & $\begin{array}{c}\text { Metro } \\
\text { Residents }\end{array}$ & $\begin{array}{c}\text { Non-Metro } \\
\text { Residents }\end{array}$ & Overall \\
\hline I do not own a vehicle now and I do not plan to get one in the future & $4.3 \%$ & $4.0 \%$ & $4.1 \%$ \\
\hline I will no longer choose to own a vehicle in less than 1 year & $0.5 \%$ & $0.2 \%$ & $0.3 \%$ \\
\hline I will no longer choose to own a vehicle in 1 to 10 years & $5.8 \%$ & $6.6 \%$ & $6.2 \%$ \\
\hline I will no longer choose to own a vehicle in 11 to 20 years & $12.7 \%$ & $11.1 \%$ & $11.8 \%$ \\
\hline I will no longer choose to own a vehicle at some point beyond 20 years & $14.6 \%$ & $12.5 \%$ & $13.4 \%$ \\
\hline I will always choose to own my own vehicle & $61.2 \%$ & $64.5 \%$ & $63.1 \%$ \\
\hline
\end{tabular}

Table 4.19 How comfortable are you with the idea of an autonomous vehicle picking up and dropping you off for a personal business appointment?

\begin{tabular}{|l|c|c|c|}
\hline & $\begin{array}{c}\text { Metro } \\
\text { Residents }\end{array}$ & $\begin{array}{c}\text { Non-Metro } \\
\text { Residents }\end{array}$ & Overall \\
\hline Very uncomfortable & $25.2 \%$ & $30.2 \%$ & $28.1 \%$ \\
\hline Uncomfortable & $17.7 \%$ & $20.1 \%$ & $19.1 \%$ \\
\hline Neutral & $28.1 \%$ & $24.8 \%$ & $26.2 \%$ \\
\hline Comfortable & $19.2 \%$ & $16.8 \%$ & $17.8 \%$ \\
\hline Very comfortable & $8.6 \%$ & $6.8 \%$ & $7.5 \%$ \\
\hline
\end{tabular}




\section{TRANSIT RIDER SURVEY SUMMARY}

\subsection{Transit Rider Respondent's Socio-Demographic Characteristics}

Among the 994 NCLS survey respondents, 152 indicated they were transit users and completed a set of questions specific to transit riders. Of the transit rider responses, 104 are from transit riders in metro communities and 48 are from transit riders in non-metro communities. Among these respondents, $53.9 \%$ are female and $46.1 \%$ are male. The percentage of female respondents was higher in non-metro areas (64.6\% female, $35.4 \%$ male) than metro areas (49\% female, $51 \%$ male). The largest share of transit rider respondents are from the age group 55 to 64 years old, followed by 64 to 74 years old, and 45 to 54 years old (Figure 5.1). Close to half of the transit riders in metro and non-metro areas lived in a two-person household (Figure 5.2). While most of the metro and non-metro transit riders are white (Figure 5.3), the percentage of transit riders that are white is lower than the percentage of total survey respondents that are white. Therefore, it can be concluded that transit users tend to be somewhat more diverse than the general public.

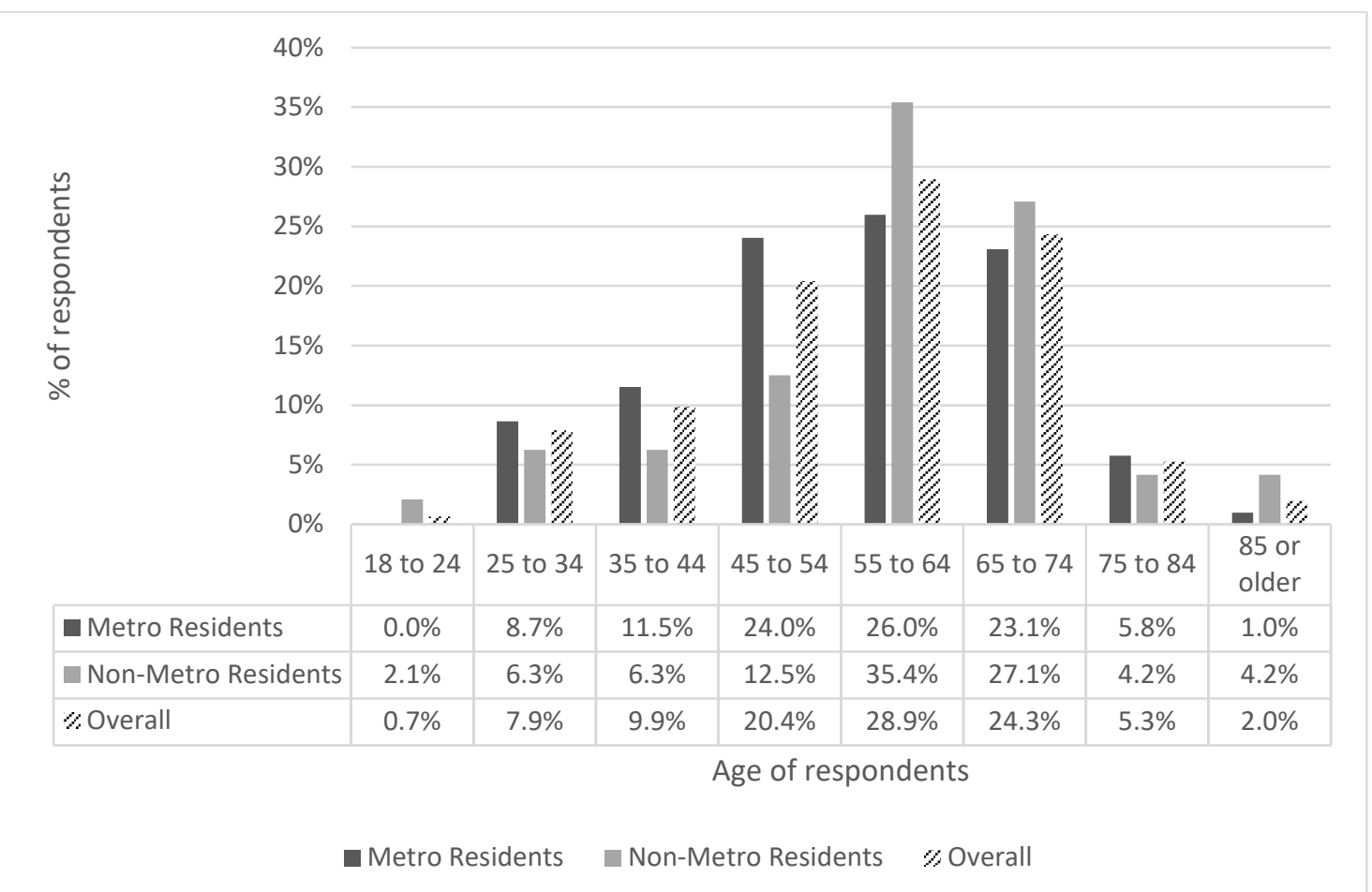

Figure 5.1 Transit riders - Percentage of respondents by age distribution for metro and nonmetro areas 


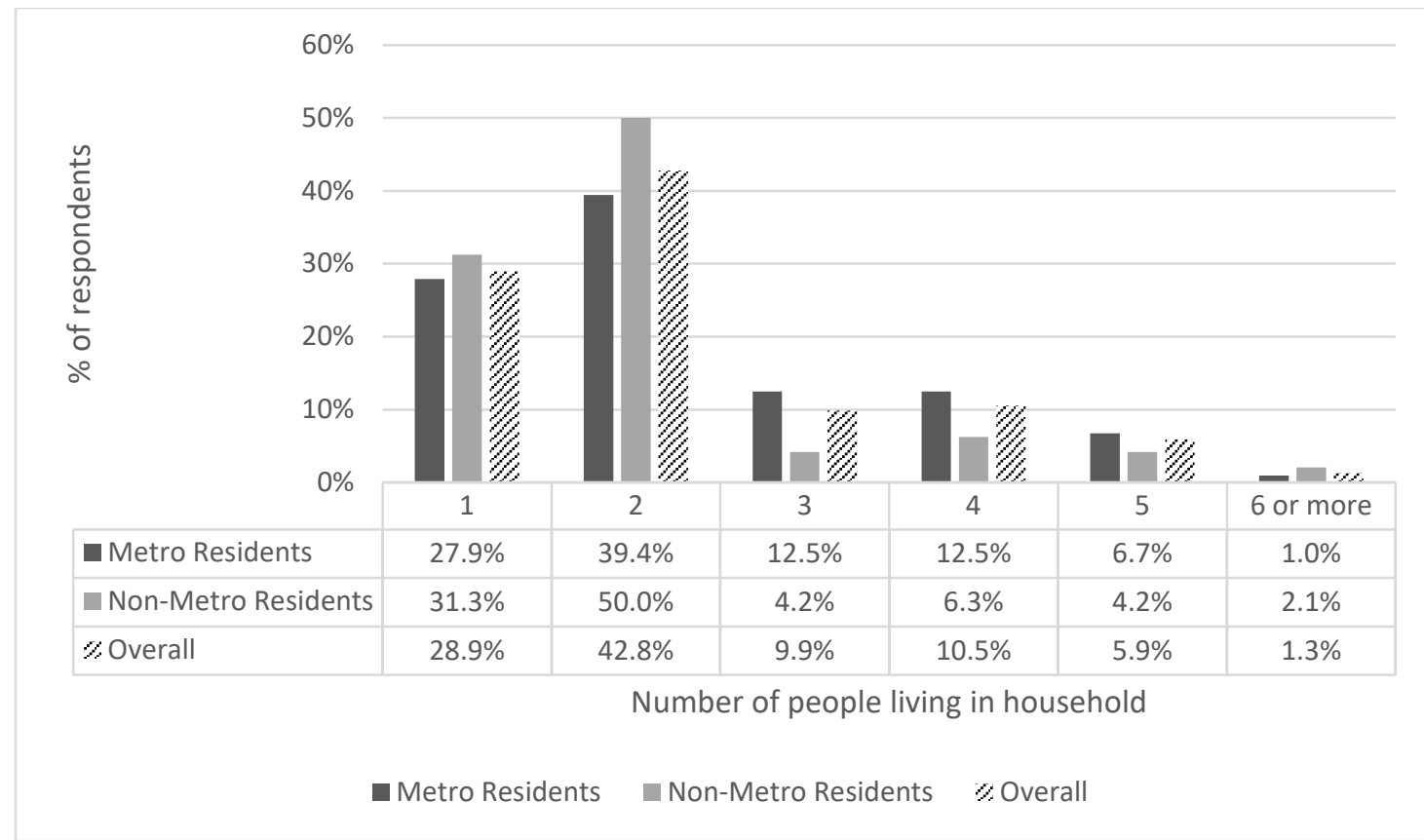

Figure 5.2 Transit riders - Including yourself, how many people live in your household?

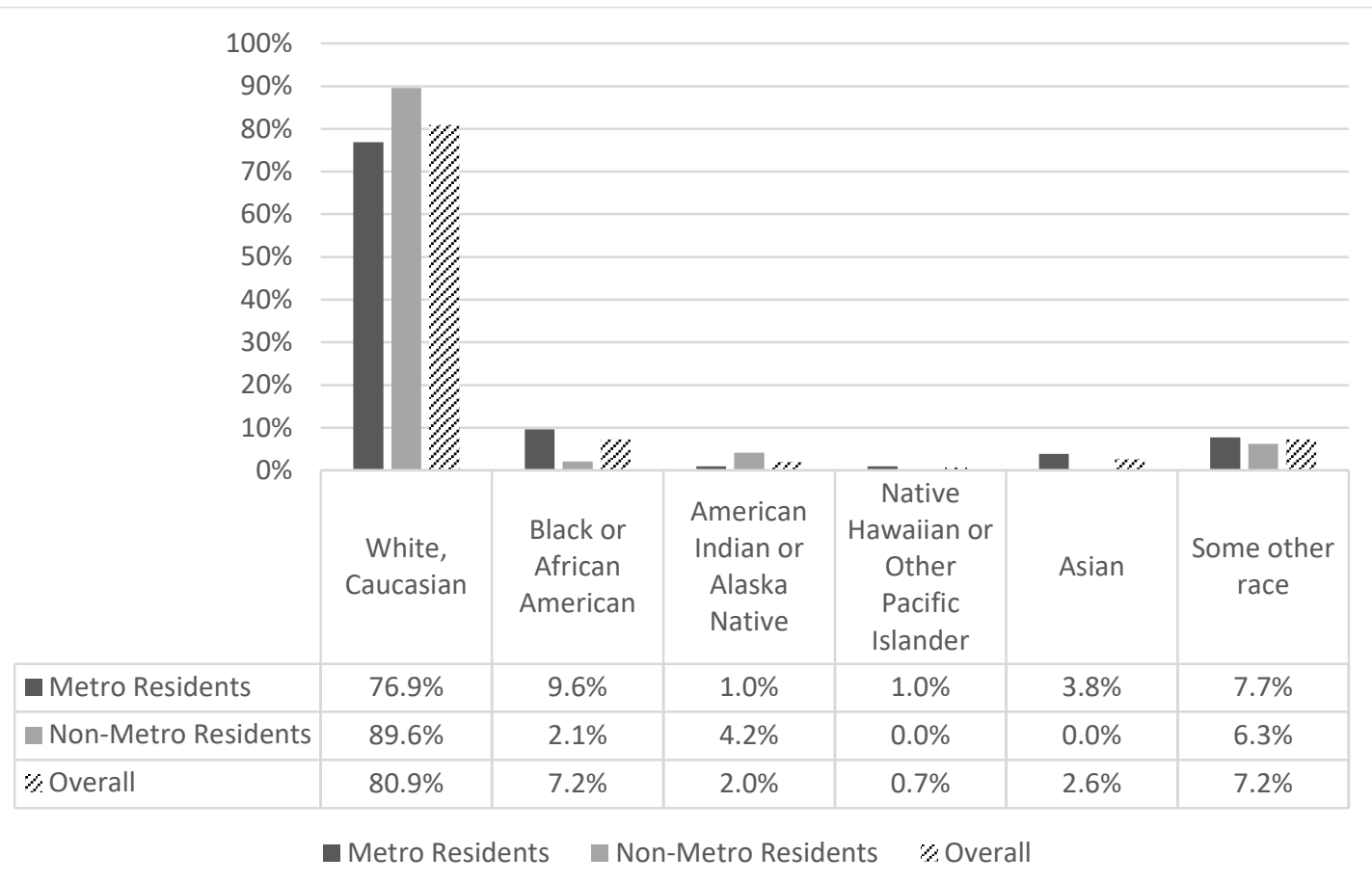

Figure 5.3 Transit riders - Percentage of respondents by race 
Most of the metro transit riders (94.2\%), and non-metro transit riders (89.6\%) have a driver's license. About $9 \%$ of metro transit riders and $12.5 \%$ of non-metro transit users do not have a vehicle in their household (Figure 5.4). These percentages are significantly higher than the overall percentage of survey respondents without a vehicle in the household (4.1\% metro, 3.3\% non-metro).

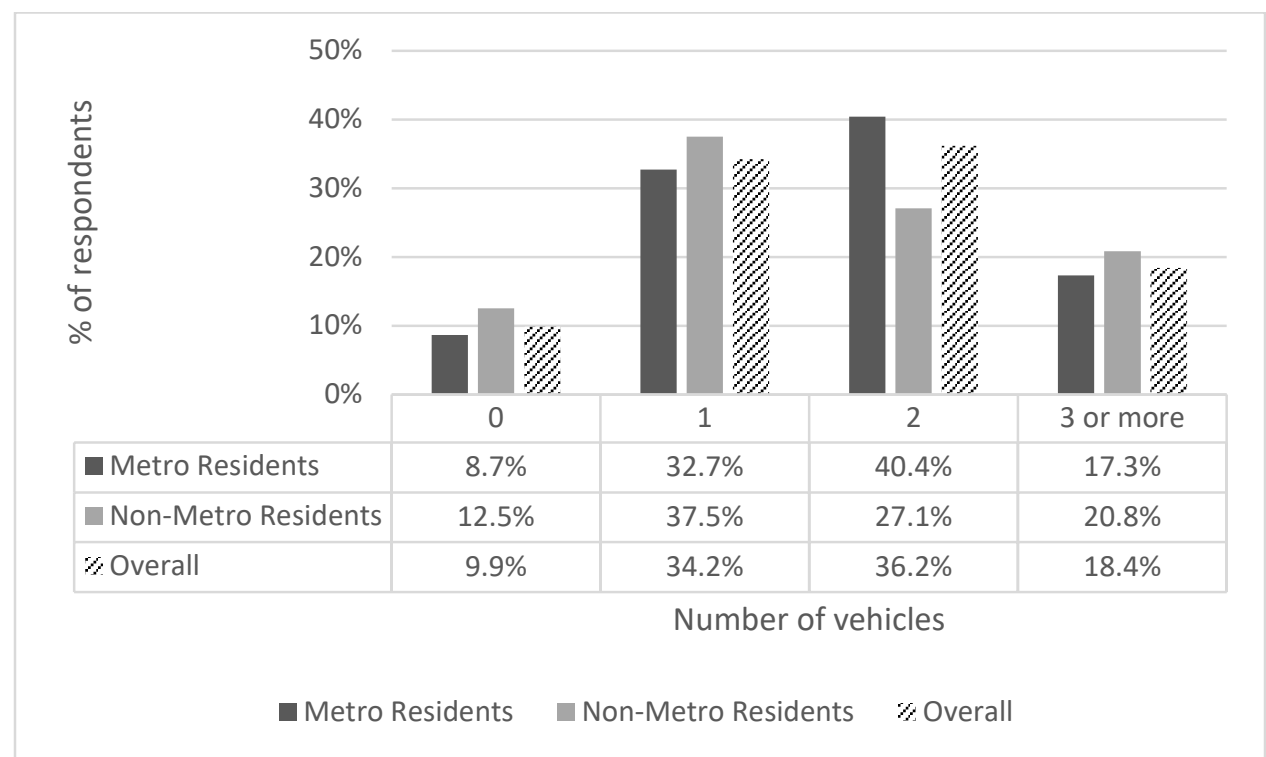

Figure 5.4 How many working vehicles (cars, trucks, and motorcycles) are available in your household?

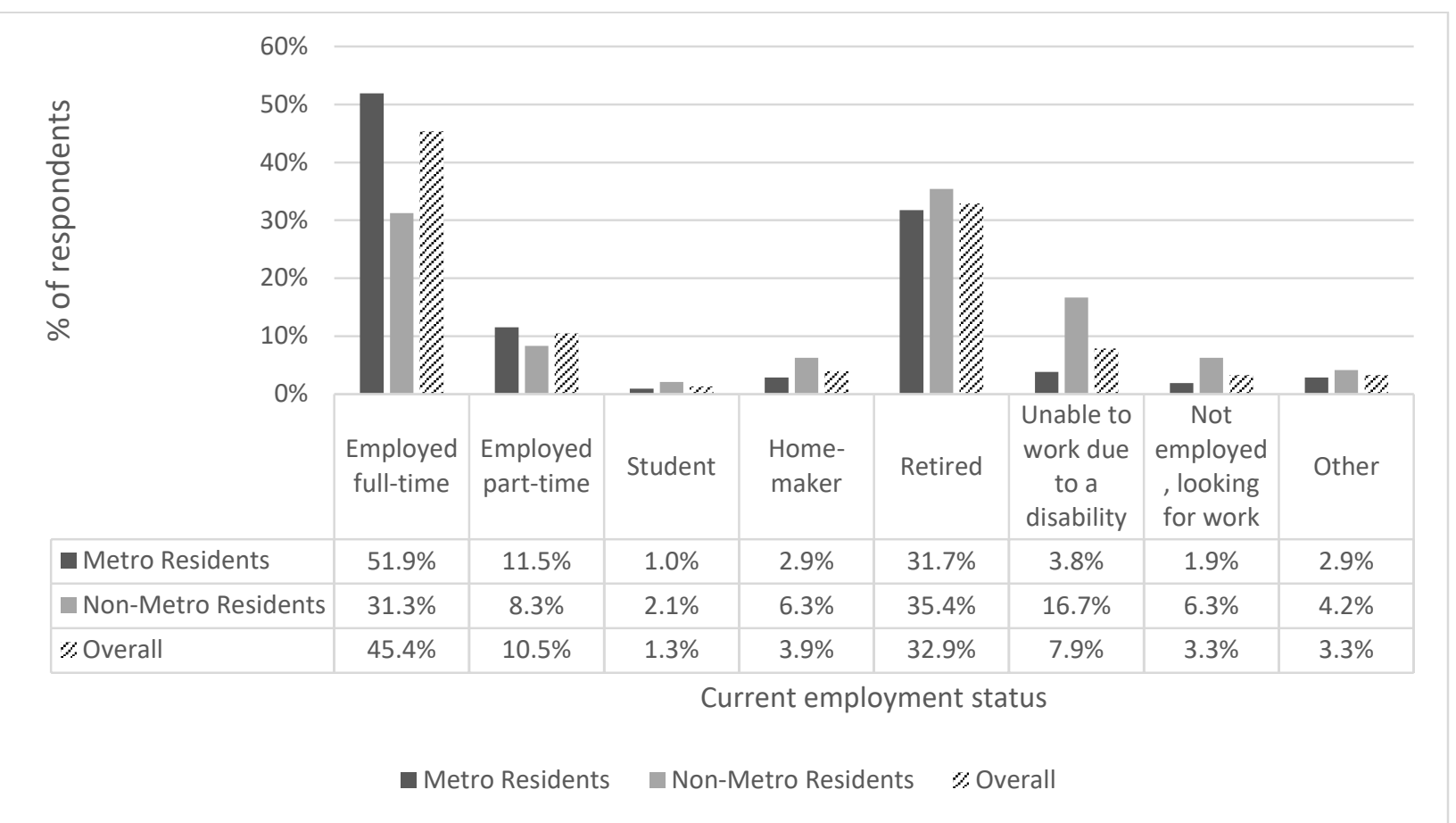

Figure 5.5 Which of the following best describes your current employment status? 
Most of the transit riders in metro areas and non-metro areas are either full-time employed or retired (Figure 5.5). In non-metro communities, more transit riders belonged to lower income groups ( $<\$ 15,000$, and $\$ 15,000$ to $\$ 24,999)$, and the percentage of transit riders decreased as income increased (Figure 5.6). However, in metro areas, the percentage of transit riders increased as household annual income increased, as the highest percentage of metro transit riders are in the household income group range $\$ 100,000$ to $\$ 249,999$ (Figure 5.6).

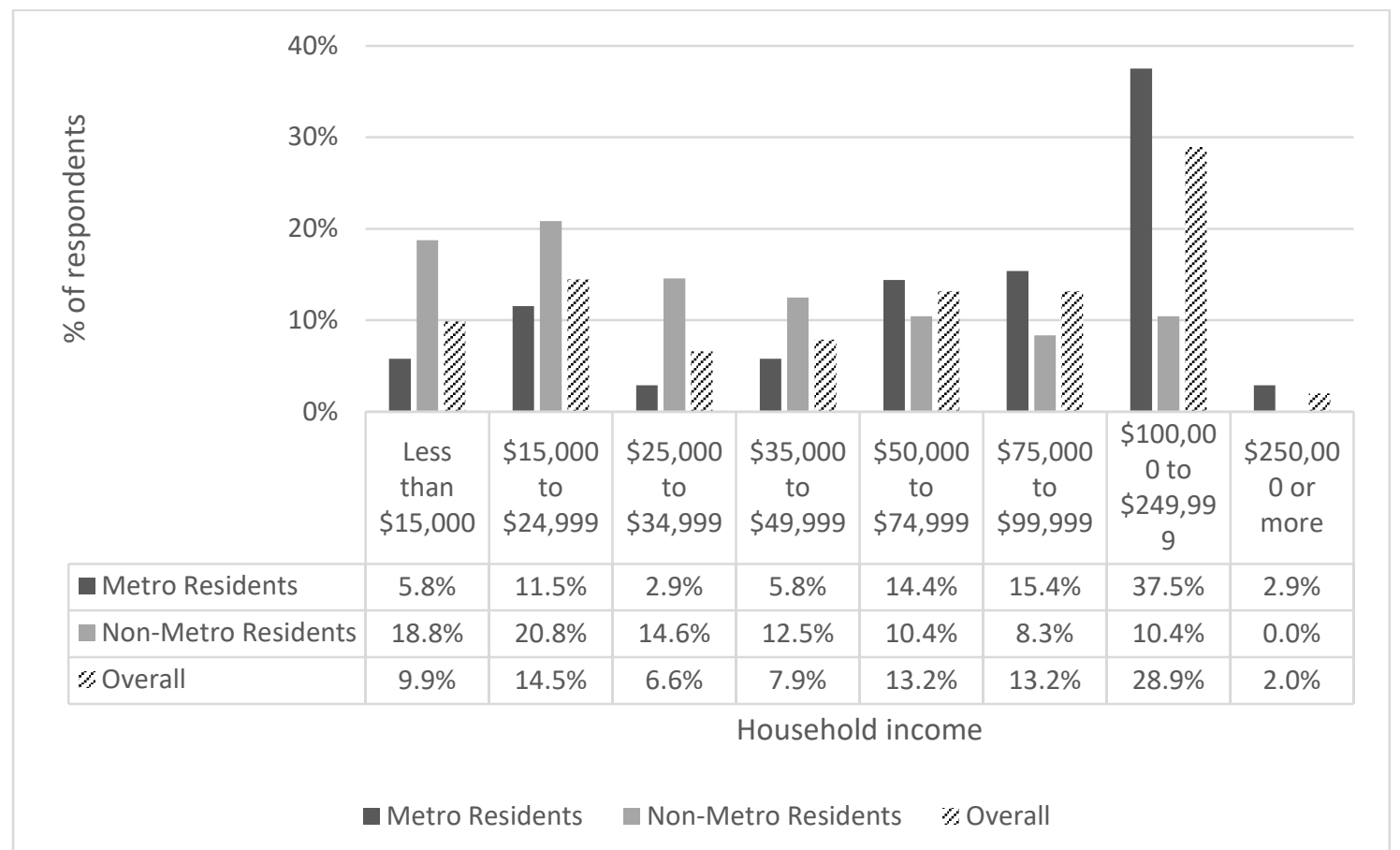

Figure 5.6 What is the combined annual income for all people living in your household?

\subsection{Transit Usage and Characteristics}

Respondents for the transit rider survey (from both metro and non-metro areas) were distributed between regular transit riders (using transit one day or more per week), and occasional transit riders (using transit two days per month or less). A number of respondents to the transit rider survey, especially in non-metro areas, were previous transit users who no longer ride transit (Figure 5.7).

When transit riders were asked if they agree or disagree with the statement, "Public transit is very important to my quality-of-life," the majority of transit riders from both metro and nonmetro areas either agreed or strongly agreed (Figure 5.8). A significant percentage of respondents from both metro and non-metro areas were neutral about the statement. Most of the respondents also mentioned they are very likely to recommend public transit service to a colleague or friend (Figure 5.9). 
The top three reasons for metro transit riders to start riding transit were: 1 ) I decided to use transit for convenience; 2) I decided to use transit to save money; and 3) I wanted to avoid congestion. The top three reasons for non-metro transit riders to start riding transit were: 1) I decided to use transit for convenience; 2) I decided to use transit to save money; and 3) I no longer had access to a vehicle (Table 5.1).

More than half of transit riders in metro areas and close to half of transit riders in non-metro areas answered that if public transit had not been available for their most recent transit trip, they would have driven their vehicle (Table 5.2). Asking a family/friend for a ride, walking, ridesourcing, and using taxi are some alternate options mentioned by some respondents in both metro and non-metro areas, and biking was noted among a small percentage of transit riders in metro areas. While a small percentage of respondents mentioned they do not have any other travel options if public transit had not been available, this percentage was higher in non-metro areas $(4.2 \%)$ when compared with metro areas (1.9\%).

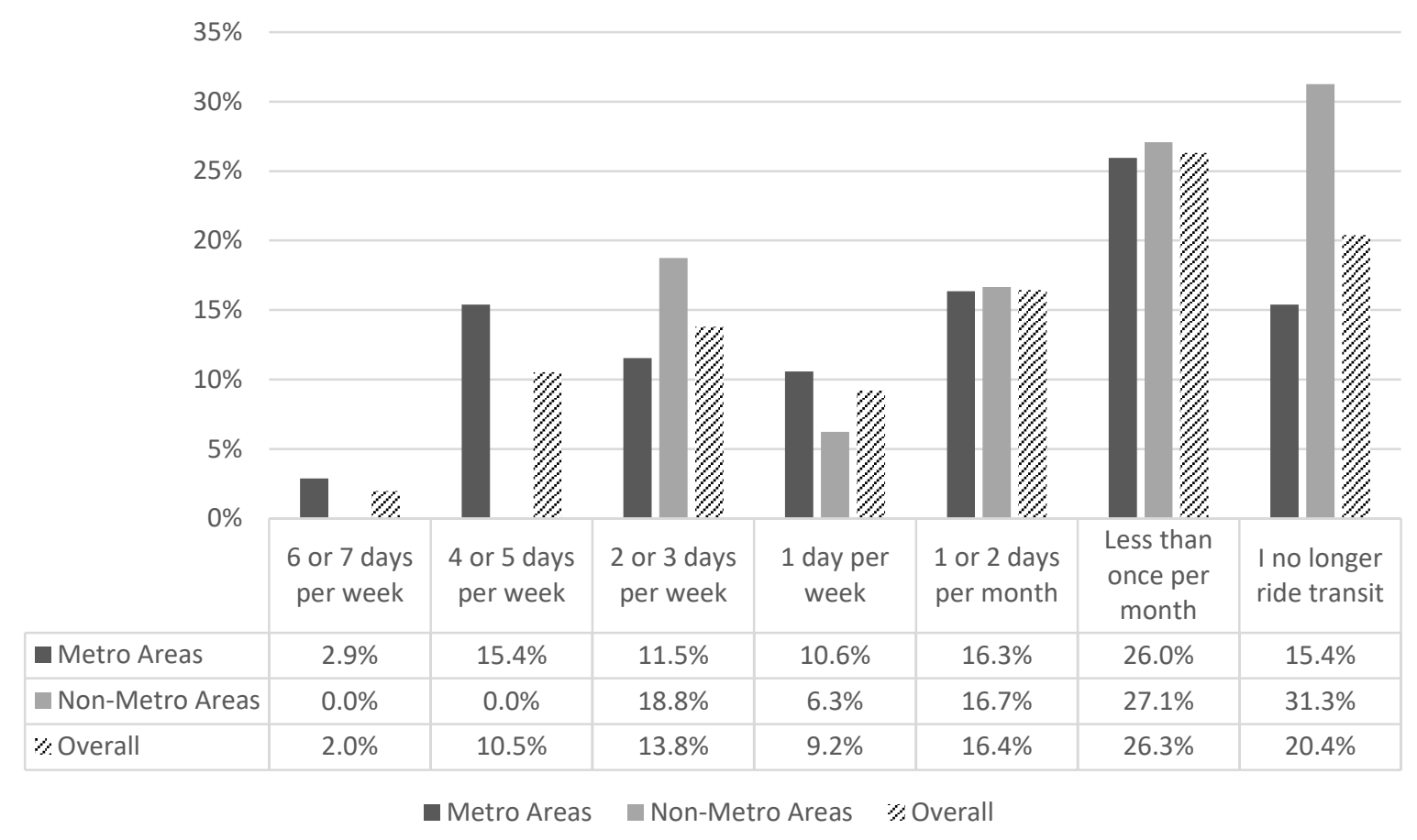

Figure 5.7 How often do you ride public transit? 

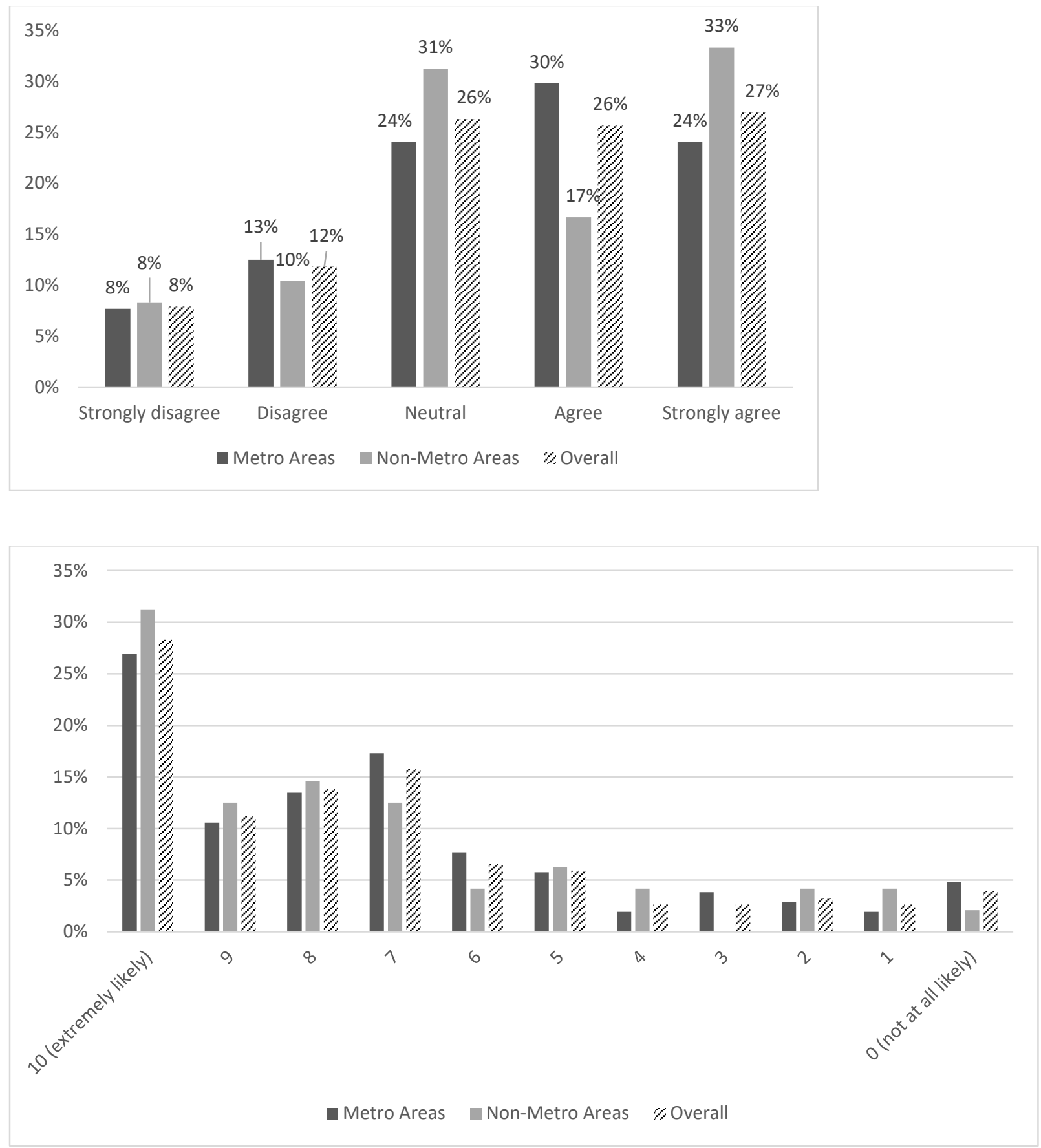

Figure 5.8 How likely is it that you would recommend the public transit service you ride to a friend or colleague? 
Table 5.1 Why did you start riding public transit?

\begin{tabular}{|l|c|c|c|}
\hline & Metro Areas & $\begin{array}{c}\text { Non-Metro } \\
\text { Areas }\end{array}$ & \multicolumn{1}{|c|}{ Overall } \\
\hline I wanted to be more physically active & $9.6 \%$ & $4.2 \%$ & $7.9 \%$ \\
\hline I enjoyed the social interaction of riding transit & $5.8 \%$ & $20.8 \%$ & $10.5 \%$ \\
\hline I decided to use transit for convenience & $43.3 \%$ & $35.4 \%$ & $40.8 \%$ \\
\hline I no longer had access to a vehicle & $15.4 \%$ & $31.3 \%$ & $20.4 \%$ \\
\hline I decided to use transit to save money & $35.6 \%$ & $31.3 \%$ & $34.2 \%$ \\
\hline I decided to use transit to reduce my energy consumption or protect air quality & $26.0 \%$ & $20.8 \%$ & $24.3 \%$ \\
\hline I did not want to drive in poor weather (rainy, snowy) & $22.1 \%$ & $20.8 \%$ & $21.7 \%$ \\
\hline I could no longer drive or had difficulties driving & $2.9 \%$ & $8.3 \%$ & $4.6 \%$ \\
\hline I could not get a ride from others or did not want to & $11.5 \%$ & $20.8 \%$ & $14.5 \%$ \\
\hline I have a disability that limits my ability to travel other ways & $3.8 \%$ & $8.3 \%$ & $5.3 \%$ \\
\hline I wanted to avoid congestion & $33.7 \%$ & $14.6 \%$ & $27.6 \%$ \\
\hline I wanted to make better use of my time while traveling & $26.9 \%$ & $14.6 \%$ & $23.0 \%$ \\
\hline Other reason(s) & $25.0 \%$ & $37.5 \%$ & $28.9 \%$ \\
\hline
\end{tabular}

Table 5.2 If public transit had not been available, which one travel option would you have used to make the trip?

\begin{tabular}{|l|c|c|c|}
\hline & Metro Areas & $\begin{array}{c}\text { Non-Metro } \\
\text { Areas }\end{array}$ & Overall \\
\hline Drove my vehicle & $55.8 \%$ & $43.8 \%$ & $52.0 \%$ \\
\hline Asked family/friend for a ride & $10.6 \%$ & $22.9 \%$ & $14.5 \%$ \\
\hline Used church of service organization & $0.0 \%$ & $0.0 \%$ & $0.0 \%$ \\
\hline Walked & $8.7 \%$ & $12.5 \%$ & $9.9 \%$ \\
\hline Biked & $3.8 \%$ & $0.0 \%$ & $2.6 \%$ \\
\hline Used bikeshare & $1.0 \%$ & $0.0 \%$ & $0.7 \%$ \\
\hline Used taxi & $5.8 \%$ & $4.2 \%$ & $5.3 \%$ \\
\hline Used ride-sourcing & $8.7 \%$ & $2.1 \%$ & $6.6 \%$ \\
\hline Used car share & $0.0 \%$ & $0.0 \%$ & $0.0 \%$ \\
\hline Used another travel option & $2.9 \%$ & $2.1 \%$ & $2.6 \%$ \\
\hline I have no other options & $1.9 \%$ & $4.2 \%$ & $2.6 \%$ \\
\hline
\end{tabular}

\subsection{Most recent transit trip}

Transit riders were asked details about their most recent trip to further understand their frequency of usage, transit mode used, and purpose of the transit trip. While a large share of transit riders made their most recent trip more than four weeks ago, a significant proportion made trips the same week, last week, or two to four weeks ago (Table 5.3). Close to half the transit riders in metro and non-metro areas made their trips using local bus, though nearly as many metro transit riders used rail (Table 5.4). Among metro transit riders, the most common trip purposes are: 1) work, and 2) social/recreational. For non-metro residents, the most common trip purposes are: 1) medical appointments, healthcare, and dental, 2) work, and 3) social/recreational. When asked specifics about the quality of service for their most recent trip, such as timeliness, driver friendliness, safety, cleanliness, comfort, and affordability, most transit users gave positive responses (Table 5.5). 
Table 5.3 When was your most recent trip on transit?

\begin{tabular}{|l|r|r|r|r|} 
& Metro Areas & $\begin{array}{c}\text { Non-Metro } \\
\text { Areas }\end{array}$ & \multicolumn{2}{c|}{ Overall } \\
\hline Today & $5.8 \%$ & $2.1 \%$ & $4.6 \%$ \\
\hline Another day this week & $19.2 \%$ & $8.3 \%$ & $15.8 \%$ \\
\hline Last week & & $17.3 \%$ & $16.7 \%$ & $17.1 \%$ \\
\hline 2 to 4 weeks ago & & $12.5 \%$ & $12.5 \%$ & $12.5 \%$ \\
\hline More than 4 weeks ago & $34.6 \%$ & $41.7 \%$ & $36.8 \%$ \\
\hline Not sure & & $9.6 \%$ & $12.5 \%$ & $10.5 \%$ \\
\hline
\end{tabular}

Table 5.4 Which mode(s) of public transit did you use on the trip?

\begin{tabular}{l|c|c|c|} 
& Metro Areas & $\begin{array}{c}\text { Non-Metro } \\
\text { Areas }\end{array}$ & Overall \\
\hline Rail (e.g., light rail, commuter rail, subway, etc.) & $47.1 \%$ & $8.3 \%$ & $34.9 \%$ \\
\hline Local Bus (e.g., fixed, flexible, deviated, etc.) & $52.9 \%$ & $43.8 \%$ & $50.0 \%$ \\
\hline Paratransit for people with disabilities & $2.9 \%$ & $14.6 \%$ & $6.6 \%$ \\
\hline Commuter Bus (e.g., express, park-and-ride, etc.) & $10.6 \%$ & $14.6 \%$ & $11.8 \%$ \\
\hline Demand Response transit (e.g., dial-a-ride, etc.) & $2.9 \%$ & $10.4 \%$ & $5.3 \%$ \\
\hline Intercity Bus (e.g., Greyhound, Megabus, etc.) & $1.9 \%$ & $6.3 \%$ & $3.3 \%$ \\
\hline Vanpool & $0.0 \%$ & $0.0 \%$ & $0.0 \%$ \\
\hline Ferry & $1.9 \%$ & $4.2 \%$ & $2.6 \%$ \\
\hline Other Mode(s) & $3.8 \%$ & $8.3 \%$ & $5.3 \%$ \\
\hline
\end{tabular}

Table 5.5 What was the purpose for the trip?

\begin{tabular}{|l|c|c|c|} 
& Metro Areas & $\begin{array}{c}\text { Non-Metro } \\
\text { Areas }\end{array}$ & Overall \\
\hline Work & $36.5 \%$ & $25.0 \%$ & $32.9 \%$ \\
\hline School, college, job training & $1.9 \%$ & $2.1 \%$ & $2.0 \%$ \\
\hline Medical appointments, health care, dental & $14.4 \%$ & $27.1 \%$ & $18.4 \%$ \\
\hline Family, personal business & $11.5 \%$ & $6.3 \%$ & $9.9 \%$ \\
\hline Social, recreational & $34.6 \%$ & $20.8 \%$ & $30.3 \%$ \\
\hline Shopping, errands & $11.5 \%$ & $12.5 \%$ & $11.8 \%$ \\
\hline Volunteering & $3.8 \%$ & $4.2 \%$ & $3.9 \%$ \\
\hline Other & $8.7 \%$ & $12.5 \%$ & $9.9 \%$ \\
\hline
\end{tabular}


Table 5.6 How much do you agree or disagree with the following statements?

\begin{tabular}{|c|c|c|c|c|c|c|c|}
\hline & & $\begin{array}{l}\text { Strongly } \\
\text { disagree }\end{array}$ & Disagree & Neutral & Agree & $\begin{array}{l}\text { Strongly } \\
\text { agree }\end{array}$ & $\begin{array}{c}\text { Does not } \\
\text { apply }\end{array}$ \\
\hline \multirow{3}{*}{ The vehicle arrived on-time } & Metro Areas & $3.8 \%$ & $5.8 \%$ & $10.6 \%$ & $42.3 \%$ & $27.9 \%$ & $4.8 \%$ \\
\hline & Non-Metro Areas & $2.1 \%$ & $6.3 \%$ & $6.3 \%$ & $41.7 \%$ & $35.4 \%$ & $0.0 \%$ \\
\hline & Overall & $3.3 \%$ & $5.9 \%$ & $9.2 \%$ & $42.1 \%$ & $30.3 \%$ & $3.3 \%$ \\
\hline \multirow{3}{*}{$\begin{array}{l}\text { The driver was helpful and } \\
\text { friendly }\end{array}$} & Metro Areas & $1.0 \%$ & $4.8 \%$ & $16.3 \%$ & $30.8 \%$ & $19.2 \%$ & $25.0 \%$ \\
\hline & Non-Metro Areas & $2.1 \%$ & $0.0 \%$ & $14.6 \%$ & $22.9 \%$ & $47.9 \%$ & $4.2 \%$ \\
\hline & Overall & $1.3 \%$ & $3.3 \%$ & $15.8 \%$ & $28.3 \%$ & $28.3 \%$ & $18.4 \%$ \\
\hline \multirow{3}{*}{ I felt safe riding transit } & Metro Areas & $2.9 \%$ & $5.8 \%$ & $7.7 \%$ & $38.5 \%$ & $42.3 \%$ & $1.0 \%$ \\
\hline & Non-Metro Areas & $2.1 \%$ & $0.0 \%$ & $6.3 \%$ & $31.3 \%$ & $50.0 \%$ & $2.1 \%$ \\
\hline & Overall & $2.6 \%$ & $3.9 \%$ & $7.2 \%$ & $36.2 \%$ & $44.7 \%$ & $1.3 \%$ \\
\hline \multirow{3}{*}{ The vehicle was clean } & Metro Areas & $1.9 \%$ & $5.8 \%$ & $14.4 \%$ & $45.2 \%$ & $26.9 \%$ & $3.8 \%$ \\
\hline & Non-Metro Areas & $2.1 \%$ & $4.2 \%$ & $6.3 \%$ & $35.4 \%$ & $41.7 \%$ & $2.1 \%$ \\
\hline & Overall & $2.0 \%$ & $5.3 \%$ & $11.8 \%$ & $42.1 \%$ & $31.6 \%$ & $3.3 \%$ \\
\hline \multirow{3}{*}{ The vehicle was comfortable } & Metro Areas & $1.9 \%$ & $3.8 \%$ & $20.2 \%$ & $47.1 \%$ & $21.2 \%$ & $3.8 \%$ \\
\hline & Non-Metro Areas & $2.1 \%$ & $0.0 \%$ & $16.7 \%$ & $35.4 \%$ & $35.4 \%$ & $2.1 \%$ \\
\hline & Overall & $2.0 \%$ & $2.6 \%$ & $19.1 \%$ & $43.4 \%$ & $25.7 \%$ & $3.3 \%$ \\
\hline \multirow{3}{*}{$\begin{array}{l}\text { The fare I paid was } \\
\text { reasonable for my trip }\end{array}$} & Metro Areas & $3.8 \%$ & $3.8 \%$ & $17.3 \%$ & $39.4 \%$ & $28.8 \%$ & $5.8 \%$ \\
\hline & Non-Metro Areas & $2.1 \%$ & $2.1 \%$ & $8.3 \%$ & $31.3 \%$ & $41.7 \%$ & $6.3 \%$ \\
\hline & Overall & $3.3 \%$ & $3.3 \%$ & $14.5 \%$ & $36.8 \%$ & $32.9 \%$ & $5.9 \%$ \\
\hline
\end{tabular}




\section{DATA ANALYSIS: IMPACTS OF TRANSPORTATION ON COMMUNITY QUALITY OF LIFE AND LIFE SATISFACTION}

The survey data can be analyzed to examine the impacts of public transportation services and other characteristics of a community's transportation system on quality of life in the community. This study estimates the impacts of transportation and other key livability factors on community quality of life and the impact of community quality of life on overall life satisfaction.

\subsection{Framework}

This study develops three models to estimate the following:

- Impacts of transportation factors on ease of travel within a community;

- Impacts of livability dimensions, including ease of travel, on community quality of life;

- Impacts of community quality of life on overall life satisfaction.

Ease of travel within a community depends on both individual and community characteristics. If an individual has the ability to drive and has access to a vehicle, it is expected that travel within the community will be relatively easier, compared with someone who cannot drive or who does not have access to a vehicle. Furthermore, if an individual has mobility limitations that makes it difficult to walk, travel within the community will likely be more difficult. A number of community characteristics also determine how easy it is to travel. These include the quality of the transit service, road quality, congestion, traffic safety, and bicycle facilities.

Ease of travel is one of many livability factors that could impact community quality of life. Leby and Hashim (2010) concluded that the livability components analyzed in most studies can be organized into four dimensions: social, physical, functional, and safety. The social dimension focuses on the relationships between neighbors and community members. The physical dimension characterizes the natural environment of communities, including parks and green spaces, and environmental quality. The functional dimension describes the private and public provision of services, accessibility to activities and amenities, and employment opportunities. Lastly, the safety dimension measures the neighborhood's safety level.

To categorize factors impacting livability, this study uses four dimensions identified by Leby and Hashim (2010). The physical dimension is expanded to include climate. The four dimensions and the indicators used in this study are shown in Table 6.1. 
Table 6.1 Livability Dimensions and Indicators

\begin{tabular}{|c|c|c|c|c|}
\hline Dimension & Social & Physical/Climate & Functional & Safety \\
\hline $\begin{array}{l}\text { Livability } \\
\text { indicator }\end{array}$ & $\begin{array}{l}\text { - Sense of } \\
\text { community }\end{array}$ & $\begin{array}{l}\text { - Parks and recreation } \\
\text { facilities } \\
\text { - Clean environment } \\
\text { - Street characteristics } \\
\text { - Walkability } \\
\text { - Weather }\end{array}$ & $\begin{array}{l}\text { - Ease of travel } \\
\text { - Available jobs } \\
\text { - Quality healthcare } \\
\text { - Quality public schools } \\
\text { - Cultural institutions } \\
\text { - Affordable housing } \\
\text { - Overall cost of living } \\
\text { - Shopping and } \\
\text { entertainment options }\end{array}$ & - Low crime \\
\hline
\end{tabular}

The functional dimension includes the largest number of indicators, which describe the community's amenities, opportunities, and accessibility. Ease of travel is included as a functional amenity because it describes how well residents are able to access amenities and activities in the community. It also relates to the physical dimension, as it is influenced by the quality of roads and the built environment, and the safety dimension, as traffic safety is an important attribute of the transportation system. The other functional indicators are available jobs, quality healthcare, quality public schools, cultural institutions, affordable housing, overall cost of living, and shopping and entertainment options.

One livability indicator is included from the social dimension: sense of community, which is a concept in psychology and sociology that focuses on the experience of community. McMillan and Chavis (1986) defined sense of community as "a feeling that members have of belonging, a feeling that members matter to one another and to the group, and a shared faith that members' needs will be met through their commitment to be together."

The physical/climate factors are parks and recreation facilities, a clean environment, the built environment, and weather. Built environment variables include the characteristics of the street the individual lives on and the walkability of the community. Walkability is determined by the quality of pedestrian infrastructure and whether land use patterns allow for trips to be easily made by walking. The crime rate is a key indicator of safety and is the only safety factor included in this study. As mentioned, traffic safety is also a component of the ease of travel.

Community quality of life is one of the domains that determines an individual's overall quality of life, or life satisfaction. Other factors that may influence life satisfaction include health, financial status, employment status, living arrangements, and demographic characteristics, such as age, gender, and marital status.

To assess the overall subjective quality of life in the community, respondents were asked the following question: "How satisfied are you with the quality of life in your community?" Respondents answered using a 5-point Likert scale, ranging from very dissatisfied to very satisfied. Responses are coded on a 1-5 scale ( $1=$ very dissatisfied and $5=$ very satisfied), and the average response is 3.9 overall, 4.0 for metro respondents, and 3.8 for non-metro respondents. 
To determine overall quality of life, or life satisfaction, survey participants were asked the following question: "All things considered, how satisfied are you with your life as a whole these days?" Respondents answered using a 0-10 scale, with a higher number indicating greater satisfaction. This question has been used in previous research as a measure of life satisfaction (Kahneman \& Krueger, 2006). The average response was 7.71 overall, 7.79 for metro respondents, and 7.65 for non-metro respondents. The distribution of responses is shown in Figure 6.1.

All things considered, how satisfied are you with your life as a whole these days?

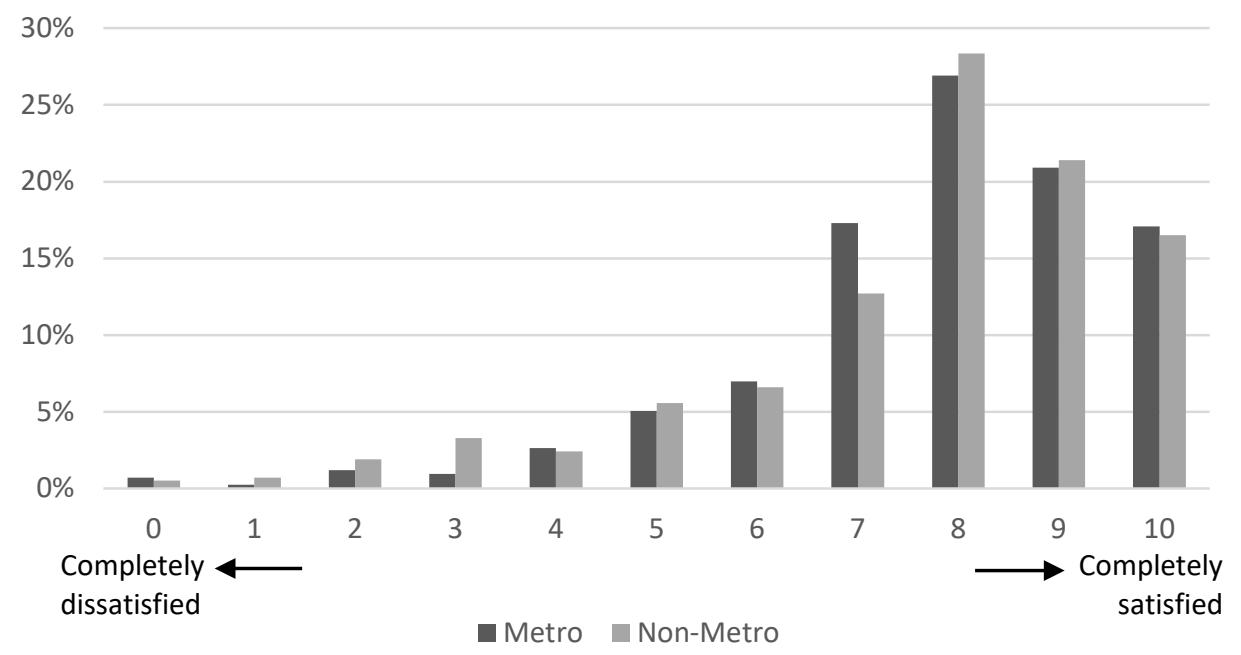

Figure 6.1 Survey Respondent Life Satisfaction Ratings, Metro vs. Non-Metro

\subsection{Model Specification}

The study developed three ordered probit models, which are used because the dependent variables are measured using an ordinal scale. The first model estimates ease of travel as a function of community transportation characteristics and individual characteristics. The second model estimates community quality of life as a function of the quality of the livability indicators. The final model estimates life satisfaction as a function of community quality of life and other factors.

Ease of travel is estimated as a function of quality of transit service, quality of roads, congestion, traffic safety, bikeability, ability to drive, access to a vehicle, and mobility impairments. It is measured with a 1-5 scale. Quality of transit service, quality of roads, congestion, traffic safety, and bikeability are also measured on a 1-5 scale, with a higher number indicating higher perceived quality. The affordable transportation options variable is not included in the model because it is highly correlated with quality of transit service. Whether the individual has a driver's license is used as a proxy for ability to drive. Access to a vehicle is 
measured as the number of vehicles available in the household. Mobility impairment is measured using a dummy variable to indicate if the respondent has serious difficulty walking or climbing stairs.

Community quality of life is estimated as a function of each of the factors listed in Table 6.1. The dependent variable and all explanatory variables except street characteristics are measured on a 1-5 scale, with a higher number indicating improved perceived quality. Street type is measured using dummy variables to indicate the type of street the respondent lives on. The open country is used as the base, and urban core street and urban center street are combined because of the low number of respondents living on these types of streets.

Life satisfaction is measured with a 0-10 scale, and it is estimated as a function of community quality of life, health, income, employment status, age, gender, and living arrangement. Health is measured with a 1-3 scale (higher number indicating better health); and income is measured with a 1-8 scale. Dummy variables are used to indicate if the individual is unemployed and looking for work or if they are retired. Because the impact of age on life satisfaction might not be linear, it is measured using dummy variables for different age groups (age 18-34 is the reference). Regarding living arrangements, a dummy variable is used to indicate if the individual is living alone.

For each of the three models, two separate models are run. The first uses survey data from all respondents, and the second limits data to those respondents from non-metro counties. Results will show if the relationships differ for non-metro areas.

\subsection{Results}

Transit quality, conditions of roads, congestion, and traffic safety were all found to have significant impacts on ease of travel (Table 6.2). Respondents who rated the quality of these attributes higher were more likely to believe that it is easy to travel within their community. With the exception of congestion, these results held for both the overall sample and the nonmetro sample, showing that the quality of transit service is important not just in urban areas, but also in smaller communities. Congestion did not have a significant impact in non-metro areas, which is not surprising. The results also show that ease of travel is greater for those with a driver's license, ease of travel increases as the number of vehicles in the household increases, and travel is significantly more difficult for those who have difficulty walking.

Ease of travel is found to be one of many factors that impact community quality of life (Table 6.3). Sense of community was found to have a significantly positive impact on community quality of life, both for the overall sample and the non-metro sample. Those respondents who rated their community as having a better sense of community gave higher ratings for overall community quality of life. 
Table 6.2 Ordered Probit Results for Ease of Travel

\begin{tabular}{|c|c|c|c|c|}
\hline Variable & $\begin{array}{l}\text { Overa } \\
\text { Estimated } \\
\text { Parameter }\end{array}$ & $\begin{array}{l}=914) \\
\quad p \text { value }\end{array}$ & $\begin{array}{l}\text { Non-Me } \\
\text { Estimated } \\
\text { Parameter }\end{array}$ & $(n=529)$ \\
\hline Intercept & -1.07 & $0.0004 * * *$ & -1.06 & $0.0074^{* * *}$ \\
\hline Transit quality & 0.19 & $<.0001 * * *$ & 0.19 & $<.0001 * * *$ \\
\hline Quality of roads & 0.15 & $0.0005 * * *$ & 0.16 & $0.0031 * * *$ \\
\hline Low congestion & 0.08 & $0.0650 *$ & -0.01 & 0.9266 \\
\hline Traffic safety & 0.23 & $<.0001 * * *$ & 0.33 & $<.0001 * * *$ \\
\hline Bikeability & 0.04 & 0.3938 & 0.00 & 0.9305 \\
\hline Driver's license & 0.66 & $0.0027 * * *$ & 0.50 & $0.0741 *$ \\
\hline Number of vehicles & 0.23 & $<.0001 * * *$ & 0.26 & $0.0001 * * *$ \\
\hline Difficulty walking & -0.42 & $<.0001 * * *$ & -0.43 & $0.0009 * * *$ \\
\hline
\end{tabular}

${ }^{*} p<10 \%,{ }^{* *} p<5 \%,{ }^{* * *} p<1 \%$

Table 6.3 Ordered Probit Results for Community Quality of Life

\begin{tabular}{|c|c|c|c|c|}
\hline Variable & $\begin{array}{r}\text { Overa } \\
\text { Estimated } \\
\text { Parameter }\end{array}$ & $\begin{array}{r}n=887) \\
p \text { value }\end{array}$ & $\begin{array}{l}\text { Non-Me } \\
\text { Estimated } \\
\text { Parameter }\end{array}$ & $\begin{array}{r}(\mathrm{n}=518) \\
p \text { value }\end{array}$ \\
\hline Intercept & -2.02 & $<.0001^{* * *}$ & -1.65 & $<.0001 * * *$ \\
\hline \multicolumn{5}{|l|}{ Social Dimension } \\
\hline Sense of community & 0.28 & $<.0001 * * *$ & 0.32 & $<.0001 * * *$ \\
\hline \multicolumn{5}{|l|}{ Physical/Climate Dimension } \\
\hline Parks and recreation facilities & -0.04 & 0.3482 & -0.02 & 0.7223 \\
\hline Clean environment & 0.10 & $0.0868^{*}$ & 0.08 & 0.2586 \\
\hline \multicolumn{5}{|l|}{ Street type (Base: Open country) } \\
\hline Urban core/center street & -0.92 & $0.0001 * * *$ & -0.95 & $0.0104 * *$ \\
\hline General urban street & -0.49 & $0.0035^{* * *}$ & -0.58 & $0.0342 * *$ \\
\hline Suburban street & -0.43 & $0.0002 * * *$ & -0.30 & $0.0558^{*}$ \\
\hline Rural street & -0.29 & $0.0042 * * *$ & -0.37 & $0.0014 * * *$ \\
\hline Walkability & 0.10 & $0.0196 * *$ & 0.12 & $0.0239 * *$ \\
\hline Weather & 0.15 & $0.0059 * * *$ & 0.09 & 0.1822 \\
\hline \multicolumn{5}{|l|}{ Function Dimension } \\
\hline Ease of travel & 0.13 & $0.0027^{* * *}$ & 0.10 & $0.0707^{*}$ \\
\hline Available jobs & 0.09 & $0.0483 * *$ & 0.08 & 0.1791 \\
\hline Quality healthcare & 0.16 & $0.0005^{* * *}$ & 0.12 & $0.0452 * *$ \\
\hline Quality public schools & 0.15 & $0.0011 * * *$ & 0.12 & $0.0332 * *$ \\
\hline Cultural institutions & 0.08 & $0.0862 *$ & 0.11 & $0.0669 *$ \\
\hline Affordable housing & -0.04 & 0.4388 & 0.02 & 0.6919 \\
\hline Overall cost of living & 0.08 & 0.1706 & 0.01 & 0.8681 \\
\hline Shopping and entertainment options & 0.18 & $0.0004 * * *$ & 0.11 & 0.1073 \\
\hline \multicolumn{5}{|l|}{ Safety Dimension } \\
\hline Low crime & 0.09 & $0.0695^{*}$ & 0.11 & 0.1158 \\
\hline
\end{tabular}


Among the physical/climate variables, the quality of parks and recreation facilities did not have a significant impact, but having a clean environment had a positive impact on community quality of life in the overall sample. Regarding street type, those who live in the open country gave the highest community quality-of-life ratings, and as the street type became more urban, quality-of-life ratings decreased. Walkability was found to have a significant positive impact on community quality of life in both the overall and non-metro models, and weather was found to have a significant positive impact in the overall model.

Many of the variables within the functional dimension had statistically significant impacts. As respondents rated the quality of these factors higher, they were more likely to rate overall community quality of life as higher. These variables include ease of travel, available jobs, quality healthcare, quality public schools, cultural institutions, and shopping and entertainment options. Affordable housing and overall cost of living did not have statistically significant impacts in either model. Available jobs and shopping and entertainment options did not have statistically significant impacts in the non-metro model, showing that these factors are less important to residents in smaller communities. Lastly, the perceived crime rate was also found to have a significant impact in the overall model.

Of all the livability indicators, sense of community was found to have the largest impact in terms of magnitude. This is true for both the overall model and the non-metro model. Street type was also found to have an important impact. The next most important factors in the overall model, in terms of the magnitudes of the effects, are shopping and entertainment options, quality healthcare, quality public schools, weather, and ease of travel.

Results from the final model show the positive impact that community quality of life has on overall life satisfaction (Table 6.4). In both the overall and non-metro models, respondents who rated their community quality of life as higher were significantly more likely to rate their overall life satisfaction as higher. An individual's health was also found to have a significant impact on their life satisfaction, as those who rated their health better gave higher life satisfaction ratings. Among the other variables, those who are unemployed and looking for work gave lower life satisfaction ratings, men had lower life satisfaction than women, and those living alone had lower life satisfaction, everything else equal. Although employment status was found to be important, the impact of household income was not statistically significant.

Lastly, age was found to have some impact on life satisfaction. Results show that, everything else being equal, life satisfaction increases for those aged 55 to 64 and then continues to increase further for those aged 65 to 74 and 75 to 84 , but then decreases for those 85 or older. 
Table 6.4 Ordered Probit Results for Life Satisfaction

\begin{tabular}{|c|c|c|c|c|}
\hline Variable & $\begin{array}{l}\text { Overa } \\
\text { Estimated } \\
\text { Parameter }\end{array}$ & $\begin{array}{l}=920) \\
p \text { value }\end{array}$ & $\begin{array}{l}\text { Non-Me } \\
\text { Estimated } \\
\text { Parameter }\end{array}$ & $\begin{array}{r}(\mathrm{n}=532) \\
\quad p \text { value }\end{array}$ \\
\hline Intercept & -0.45 & 0.1188 & -0.61 & 0.1026 \\
\hline Community quality of life & 0.42 & $<.0001 * * *$ & 0.43 & $<.0001 * * *$ \\
\hline Health & 0.68 & $<.0001 * * *$ & 0.70 & $<.0001 * * *$ \\
\hline Household income & 0.02 & 0.2712 & 0.04 & 0.1416 \\
\hline Unemployed & -0.77 & $0.0045 * * *$ & -0.21 & 0.6021 \\
\hline Retired & 0.12 & 0.2508 & 0.14 & 0.3199 \\
\hline Age (Base: Age 18 to 34) & & & & \\
\hline Age 35 to 44 & 0.12 & 0.445 & -0.02 & 0.9376 \\
\hline Age 45 to 54 & 0.09 & 0.5156 & -0.03 & 0.8824 \\
\hline Age 55 to 64 & 0.27 & $0.0472 * *$ & 0.21 & 0.2393 \\
\hline Age 65 to 74 & 0.37 & $0.0203 * *$ & 0.28 & 0.1976 \\
\hline Age 75 to 84 & 0.68 & $0.0003 * * *$ & 0.43 & $0.0738 *$ \\
\hline Age 85 or older & 0.33 & 0.1801 & 0.17 & 0.5794 \\
\hline Male & -0.16 & $0.0216 * *$ & -0.08 & 0.405 \\
\hline Living alone & -0.19 & $0.0274 * *$ & -0.07 & 0.5482 \\
\hline
\end{tabular}

${ }^{*} p<10 \%,{ }^{* *} p<5 \%,{ }^{* * *} p<1 \%$ 


\section{SUMMARY AND CONCLUSIONS}

The National Community Livability Survey (NCLS) contacted 25,000 adults from all 50 U.S. states. The research team stratified the NCLS random survey outreach by four U.S. regions and nine census divisions (Figure 2.1). The random survey was further stratified by sex and age to ensure research participants were proportional to the adult population. A total of 994 highquality responses were received. Survey participants were categorized as living in metro or nonmetro areas based on the Rural-Urban Continuum Codes (RUCC) for their county of residence. Among 994 responses, 152 were from transit users who completed the follow-up transit rider survey.

An analysis of survey responses regarding the importance of different livability factors and the quality of those factors in the respondent's community provides insight on how livability could be improved. In metro areas, livability could be improved the most by improving the availability of jobs, affordable housing, affordable transportation options, and reducing crime. Similarly, livability could be improved in non-metro areas by improving the availability of jobs, affordable housing, quality healthcare, and affordable transportation options. Further, when compared with metro communities, non-metro communities have a greater need to improve the identified livability factors, as there is a large gap for improvement.

Findings also show that improvements in transportation conditions would improve community livability. In both metro and non-metro areas, this includes improvements to road conditions, public transit services, and walkability/accessibility. Reducing congestion would also have a positive impact in metro areas.

While a majority of metro and non-metro residents agree or strongly agree that they can easily travel to places they need to go in their respective communities using their current travel options, a small percentage of respondents have difficulties. A higher percentage of non-metro residents have difficulties making trips, compared with their metro counterparts. In general, transportation options in rural communities are limited; therefore, there is a need to provide more transportation options to increase mobility.

A majority of respondents from both metro and non-metro communities agree or strongly agree that it is important for public transit to be available in their community. Metro residents are found to use public transit three times more when compared with non-metro respondents. However, among respondents currently lacking access to transit, non-metro residents were two times more likely to say they would use it if it were available. Less public transit usage in nonmetro areas could be attributed to lack of proper transit service. Public transit is considered accessible to more than half of metro residents to make trips from their residence to various types of destinations, transit accessibility is comparatively less for non-metro residents.

Among the 152 transit rider respondents, 104 are from transit riders in metro communities, and 48 are from transit riders in non-metro communities. In non-metro communities, more transit riders belonged to lower income groups, and the percentage of transit riders decreased as income increased. However, the highest percentage of metro transit riders is in the household income group range $\$ 100,000$ to $\$ 249,999$. A majority of the transit riders from both 
metro and non-metro areas either agreed or strongly agreed that public transit is very important to their quality of life. The top three reasons for metro transit riders to start riding transit are: 1) I decided to use transit for convenience, 2) I decided to use transit to save money, and 3) I wanted to avoid congestion. The top three reasons for non-metro transit riders to start riding transit are: 1) I decided to use transit for convenience, 2) I decided to use transit to save money, and 3) I no longer had access to a vehicle.

Results from the data analysis ultimately show the relationships between transportation and quality of life. If residents have more positive perceptions about the quality of transit service, road conditions, and traffic safety, they are more likely to believe that it is easy to travel within their community, which positively impacts their perception of community quality of life. This ultimately impacts overall life satisfaction, as results show the positive impact of community quality of life on life satisfaction, or subjective well-being. These relationships were found to exist in both metro and non-metro communities. Results from this study support efforts to improve community livability and subjective well-being through improvements in public transit services, traffic safety, and walkability. 


\section{REFERENCES}

Brooks, J., Edrington, S., Sharma, S., Vasishth, S., \& Cherrington, L. (2014). Exploring Transit's Contribution to Livability in Rural Communities: Guidebook and Exercises; Technical Memorandum 1 - Literature Review: Transit and Livability in Rural America. Texas A\&M Transportation Institute.

Brooks, J., Sharma, S., Pappas, M., \& Cherrington, L. (2015). Exploring Transit's Contribution to Livability in Rural Communities: Guidebook and Exercises; Technical Memorandum 3 Pilot Case Study Findings and Phase 2 Case Study Outreach Plan. Texas A\&M Transportation Institute.

Godavarthy, R., \& Mattson, J. (2016). Exploring Transit's Contribution to Livability in Rural Communities: Case Study of Valley City, ND, and Dickinson, ND. Small Urban and Rural Transit Center, Upper Great Plains Transportation Institute.

Kahneman, D., \& Krueger, A. B. (2006). "Developments in the Measurement of Subjective WellBeing." Journal of Economic Perspectives, 20(1), 3-24.

Leby, J. L., \& Hashim, A. H. (2010). "Liveability Dimensions and Attributes: Their Relative Importance in the Eyes of Neighbourhood Residents." Journal of Construction in Developing Countries, 15(1), 67-91.

McMillan, D. W., \& Chavis, D. M. (1986). "Sense of Community: A Definition and Theory." Journal of Community Psychology, 14, 6-23. 


\section{APPENDIX A: NCLS OUTREACH MATERIALS}

Source: Jonathan et. al Forthcoming

\section{Initial Contact Email}

The research team purchased an email address for participants, when available. The existence of an email address in no way influenced which adults were randomly selected. Rather, the email was requested for records already selected by the address vendor based on the sampling methodology described earlier in this report.

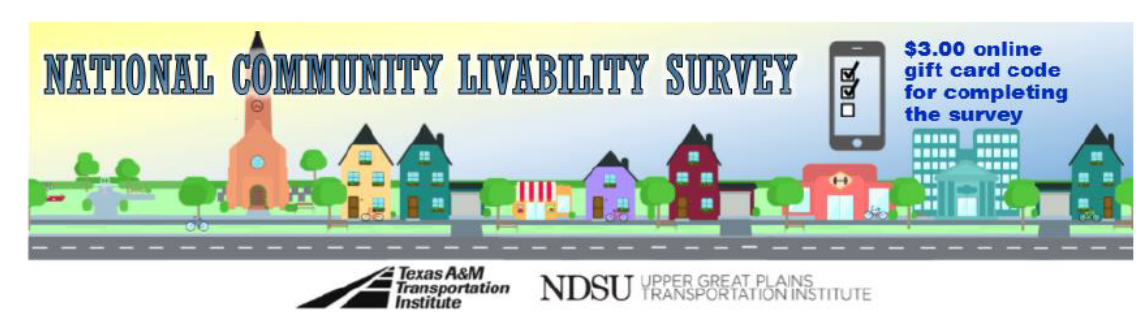

Hello. I lead a team of researchers at Texas A\&M University and North Dakota State University conducting the first ever National Community Livability Survey. We invite you to participate by completing the survey (about 15 minutes, mobile-friendly). Participation is voluntary and your responses confidential. We will send you one $\$ \mathbf{3 . 0 0}$ online gift card code for completing the survey. You were randomly selected to receive this email because you are age 18 or over and live in the United States. This is the only time we will email you about this opportunity.

Survey in English: www.livabilitysurvey.com

Your password to the survey is $\mathbf{1 1 1 1 1 1 1 1 1 1}$

Encuesta en Español: http://spa.livabilitysurvey.com

中文调查 : http://chi.livabilitysurvey.com

Khảo sát tại Việt : http://vie.livabilitysurvey.com

한국어로 된 설문 조사 : http://kor.livabilitysurvey.com

You may learn more about the research study by visiting: https://tti.tamu.edu/group/transitmobility/resources/nls/.

Thank you and have a great day,

Jonathan P. Brooks

Assistant Research Scientist

Transit Mobility Program

Texas A\&M Transportation Institute

A Member of the Texas A\&M University System

Office 713.613.9206 Email transitsurvey@tti.tamu.edu

For questions about your rights as a research participant, to provide input regarding research, or if you have questions, complaints, or concerns about the research, you may call the Texas A\&M University Human Research Protection Program office by phone toll free at 1-855-795-8636 or by email at irb@tamu.edu. IRB Protocol \#2017-0093 


\section{Postcard}

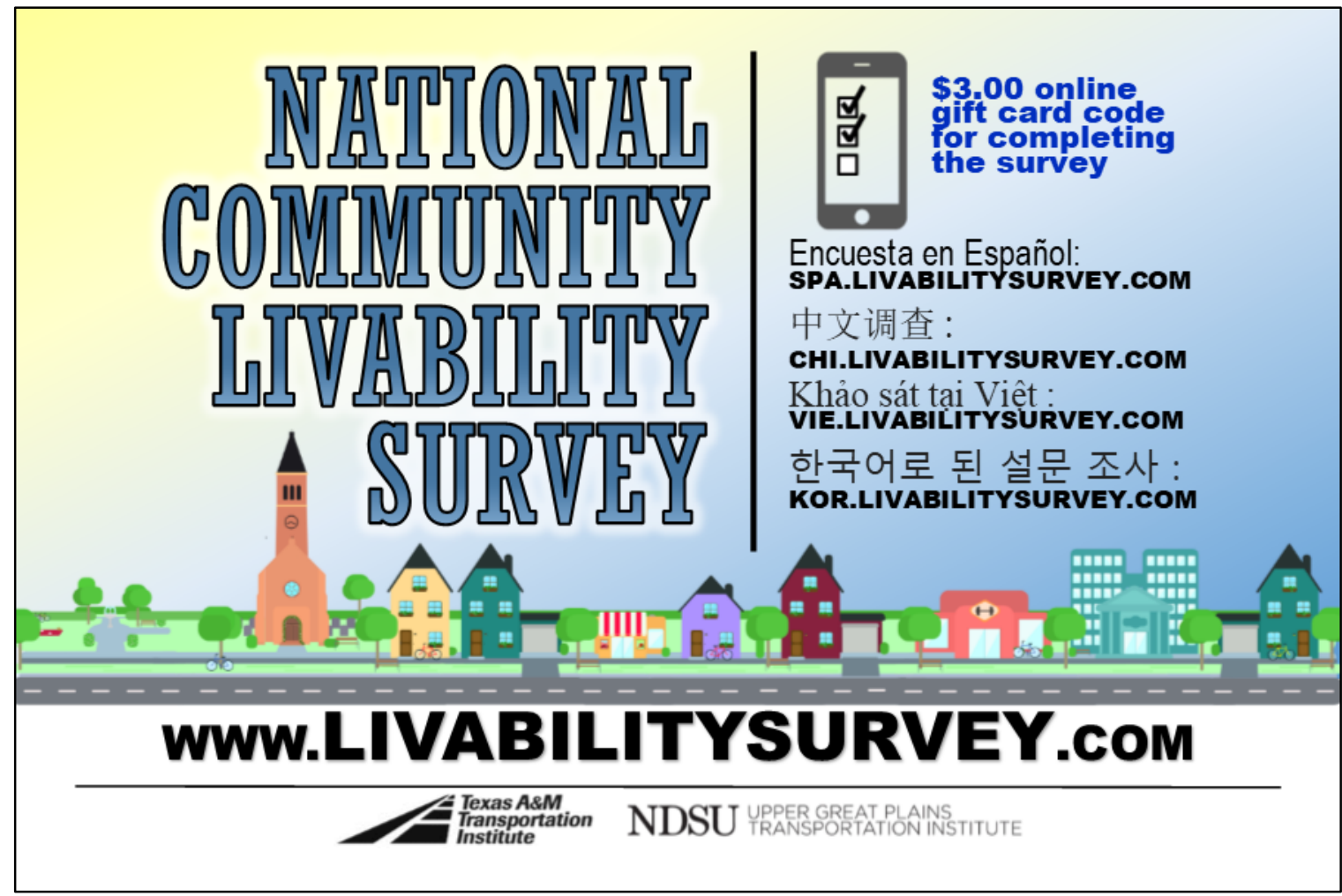

Hello,

Researchers from Texas A\&M University and North Dakota State University are conducting the first National Community Livability Survey. We invite you to participate by completing the survey online (15 minutes, mobile-friendly).

Participation is voluntary and your responses are confidential. We will send you one $\mathbf{\$ 3 . 0 0}$ online gift card for completing the survey.

\section{LIVABIL Survey in English:}

Encuesta en Español:

SPA.LIVABILITYSURVEY.COM

中文调查:

CHI.LIVABILITYSURVEY.COM Khao sát tai Viêt: 한국어로 된 설문 조사

KOR.LIVABILITYSURVEY.COM

\section{Your survey password is: «Passcode»}

Thank you, Jonathan Brooks

Phone 1-713-613-9206

Email j-brooks@tti.tamu.edu
Texas A\&M Transportation Institute

701 N Post Oak Rd, Ste 430

Houston, TX $77024-3827$

"AddressBlock» 


\section{Full Form Mailer Send Envelope}

The full form mailer envelope used to send materials to potential research participants included the following logo and text in the upper left-hand corner.

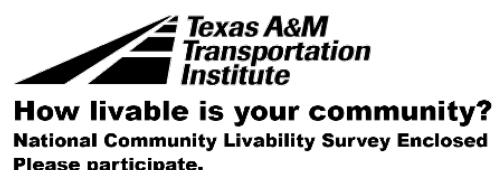

\section{Business Reply Mail Return Envelope}

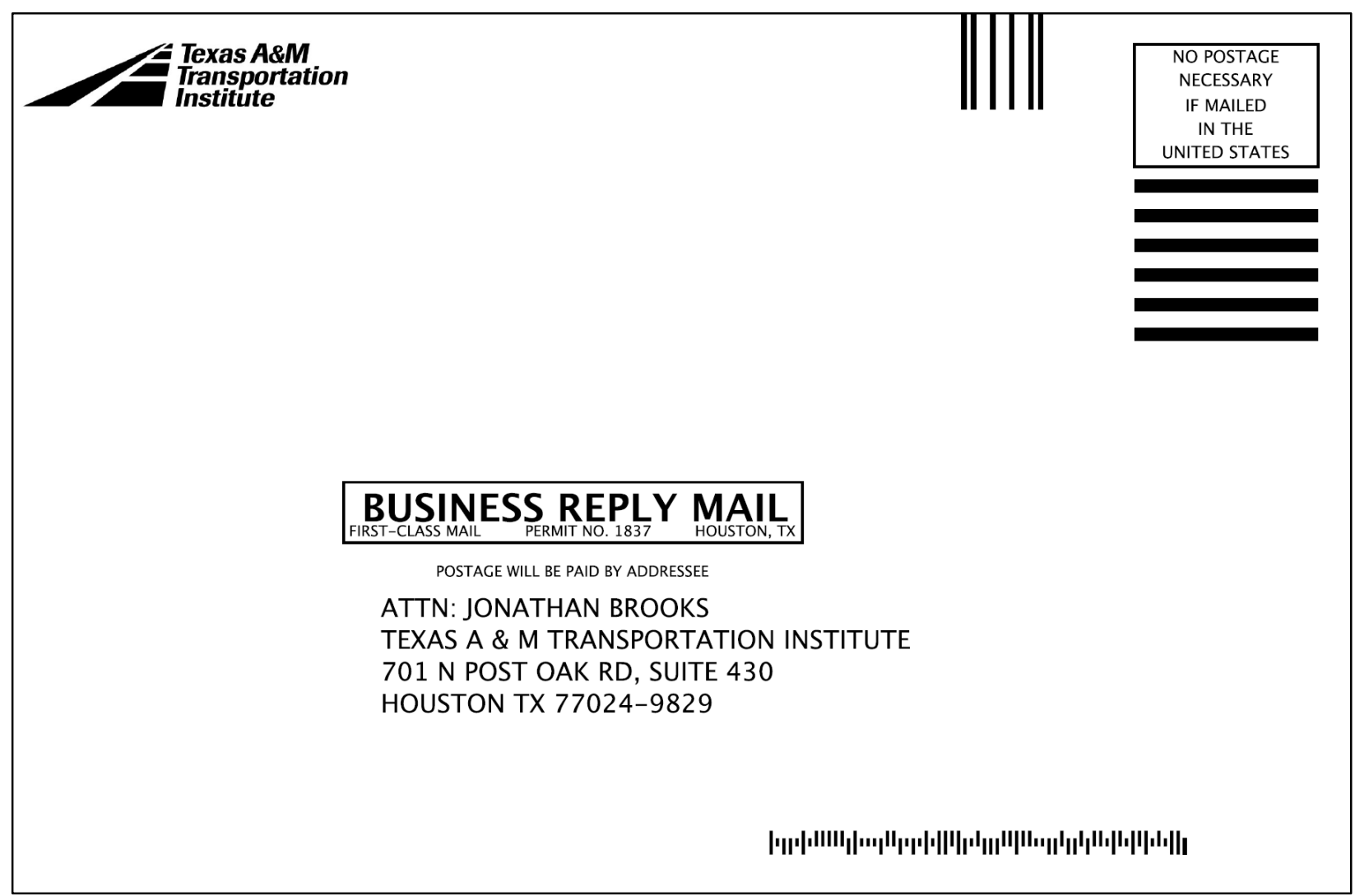




\section{Full Form Mailer Letter: English}

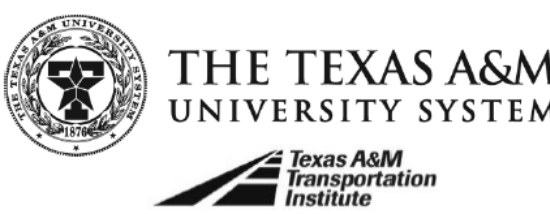

Dear [Mail-merge name],

\section{NDSU NORTH DAKOTA \\ STATE UNIVERSITY}

NDSU UPDER GEEAT PAANS TRANPRORATION NISTUTE

[Mail-merge date]

My name is Jonathan Brooks. I lead a team of researchers from Texas A\&M University's Texas A\&M Transportation Institute and North Dakota State University's Upper Great Plains Transportation Institute. We are conducting research funded by the U.S. Department of Transportation about what makes a community a great place to live and if/how public transit plays a role in quality-of-life. Our study includes surveying the public and transit riders about their communities. Your participation is needed and important.

We randomly selected you because you are age 18 or over and live in the United States. We invite you to participate in our research by completing the enclosed survey. Participation is voluntary and your responses confidential. The survey takes about 15-20 minutes to complete. We will combine your responses with those of all other respondents and report findings in summary form only. You may choose not to participate by not returning the survey; without any penalty.

Please take the time to thoughtfully complete the survey. We will send you one $\$ 3.00$ online gift card code in return for your providing a survey response with all questions answered. You may complete the enclosed paper survey (postage paid return) or take the survey online (mobile friendly):

www.livabilitysurvey.com

Please respond in the next two weeks!

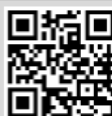

回要要

Encuesta en Español: http://spa.livabilitysurvey.com

中文调查 : http://chi.livabilitysurvey.com

Khảo sát tại Việt : http://vie.livabilitysurvey.com

한국어로 된 설문 조사 : http://kor.livabilitysurvey.com

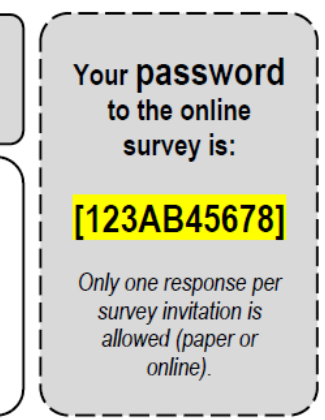

If you have any questions or need assistance taking the survey call me at 1-713-613-9206 or email me at j-brooks@tti.tamu.edu. Thank you for your participation in this research. Have a great, safe day!

[Mail-merge name] or current resident

[Mail-merge street address 1]

[Mail-merge street address 2]

[Mail-merge city, state, ZIP+4]

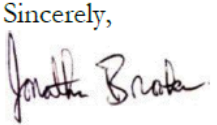

Texas A\&M Transportation Institute

701 N Post Oak Rd. Suite 430. Houston. TX 77024

For questions about your rights as a research participant, to provide input regarding research, or if you have questions, complaints, or concerns about the research, you may call the Texas A\&M University Human Research Protection Program office by phone toll free at 1-855795-8636 or by email at irb@tamu.edu. IRB Protocol \#2017-0093 
Full Form Mailer Letter: Spanish

\section{THE TEXAS A\&M UNIVERSITY SYSTEM ETexas A\&M institute \\ NDSU NORTH DAKOTA NDSU STATE UNIVERSITY NDSU UPPER GREAT PLAINS}

[Mail-merge date]

Estimado [Mail-merge name],

Me llamo Jonathan Brooks y dirijo un equipo de investigadores en el Instituto de Transporte de la Universidad Texas A\&M (TTI, por sus siglas en inglés) y el Instituto de Transporte Upper Great Plains de la Universidad estatal de Dakota del Norte. Estamos realizando estudios de investigación financiados por el Departamento de Transporte para conocer los factores que contribuyen a que una comunidad sea un buen lugar para vivir y si el transporte público desempeña un papel, y de qué modo, en la calidad de vida en dicha comunidad. Nuestro estudio incluye encuestas entre el público y los pasajeros de transporte público para conocer sus experiencias en la comunidad. Su opinión es necesaria e importante.

Usted ha sido seleccionado al azar por ser mayor de 18 años y vivir en los Estados Unidos. Le invitamos a participar en nuestra investigación, para lo cual debe rellenar la encuesta adjunta. Su participación es voluntaria y sus respuestas son confidenciales. Tardará unos 15 a 20 minutos en completar la encuesta. Nosotros combinaremos sus respuestas con las del resto de los encuestados y anunciaremos las conclusiones en forma de resumen solamente. Si decide no participar no es necesario que devuelva la encuesta. No será penalizado.

Le agradecemos dedique el tiempo necesario para completar detalladamente la encuesta. Le enviaremos una tarjeta regalo codificada por valor de $\$ 3.00$ cuando nos devuelva la encuesta totalmente completada. También puede completar la encuesta rellenando la copia impresa adjunta y devolviéndola por correo en el sobre con franqueo pagado que se le proporciona. O puede hacerlo online desde su dispositivo móvil, visitando:

http://spa.livabilitysurvey.com
Le agradecemos responda en las próximas dos semanas.

Survey in English: www.livabilitysurvey.com

中文调查 : http://chi.livabilitysurvey.com

Khảo sát tại Việt : http://vie.livabilitysurvey.com

한국어로 된 설문 조사 : http://kor.livabilitysurvey.com
Su contraseña para completar la encuesta es:

\section{[123AB45678]}

Solamente se permite una respuesta por cada invitación para completar la encuesta (impresa u online).

Si tiene preguntas o necesita ayuda para completar la encuesta, no dude en comunicarse conmigo llamando al 1-713-613-9206, o por correo electrónico a j-brooks@tti.tamu.edu. Le agradecemos su participación en este estudio de investigación. Le deseamos un día seguro y agradable.

[Mail-merge name] or current resident [Mail-merge street address 1] [Mail-merge street address 2] [Mail-merge city, state, ZIP+4]

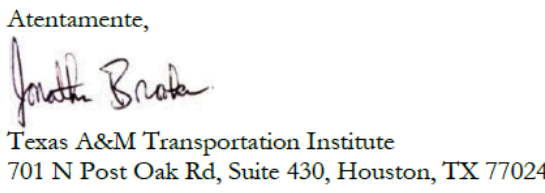

Si tiene preguntas acerca de sus derechos como participante en un estudio de investigación, o desea ofrecer opiniones acerca de la investigación, o tiene dudas, quejas o inquietudes acerca de la investigación, puede llamar a la oficina del Programa de protección de seres humanos en la investigación de la Universidad Texas A\&M, llamando al 1-855-795-8636, o por correo electrónico a irb@tamu.edu. Protocolo IRB \#2017-0093 


\section{Mailer Survey Instrument: English}

\section{Page 1 of 8}

\section{START HERE}

Think about the 1,000s of communities in America..

1. In your opinion, how important is each factor to community livability? Check one per row.

\begin{tabular}{|c|c|c|c|c|c|}
\hline Available jobs ......................................... & $\begin{array}{l}\text { Not } \\
\text { important } \\
0\end{array}$ & $\begin{array}{l}\text { Slightly } \\
\text { important } \\
\bigcirc\end{array}$ & $\begin{array}{l}\text { Moderately } \\
\text { important } \\
\bigcirc\end{array}$ & $\begin{array}{c}\text { Important } \\
\bigcirc\end{array}$ & $\begin{array}{l}\text { Very } \\
\text { important } \\
\bigcirc\end{array}$ \\
\hline Affordable transportation options ....... & 0 & 0 & 0 & 0 & 0 \\
\hline Cultural institutions & 0 & 0 & 0 & 0 & 0 \\
\hline Quality healthcare ....................................... & 0 & 0 & 0 & 0 & 0 \\
\hline Affordable housing & $\mathrm{O}$ & $\bigcirc$ & $\mathrm{O}$ & O & 0 \\
\hline Quality public schools ................................. & 0 & 0 & 0 & 0 & 0 \\
\hline Overall cost of living & $\mathrm{O}$ & $\mathrm{O}$ & $\mathrm{O}$ & $\mathrm{O}$ & $\mathrm{O}$ \\
\hline Shopping and entertainment options ... & 0 & 0 & 0 & 0 & 0 \\
\hline Parks and recreation facilities .................... & $\mathrm{O}$ & $\bigcirc$ & $\mathrm{O}$ & O & $\mathrm{O}$ \\
\hline 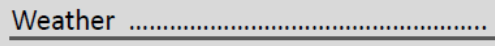 & 0 & 0 & $\mathrm{O}$ & $\mathrm{O}$ & $\mathrm{O}$ \\
\hline Clean environment & $\mathrm{O}$ & $\mathrm{O}$ & $\mathrm{O}$ & $\mathrm{O}$ & $\mathrm{O}$ \\
\hline Low crime & 0 & 0 & $\mathrm{O}$ & 0 & $\mathrm{O}$ \\
\hline Sense of community & $\mathrm{O}$ & $\mathrm{O}$ & $\mathrm{O}$ & $\mathrm{O}$ & O \\
\hline 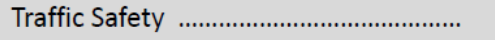 & $\mathrm{O}$ & $\mathrm{O}$ & $\mathrm{O}$ & $\mathrm{O}$ & $\mathrm{O}$ \\
\hline
\end{tabular}

2. How important is each aspect of transportation to community livability? Check one per row.

\begin{tabular}{|c|c|c|c|c|c|}
\hline Public transit services .................................. & $\begin{array}{l}\text { Not } \\
\text { important } \\
0\end{array}$ & $\begin{array}{l}\text { Slightly } \\
\text { important } \\
\bigcirc\end{array}$ & $\begin{array}{l}\text { Moderately } \\
\text { important } \\
\bigcirc\end{array}$ & Important & $\begin{array}{l}\text { Very } \\
\text { important } \\
\bigcirc\end{array}$ \\
\hline 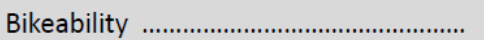 & 0 & 0 & 0 & 0 & 0 \\
\hline 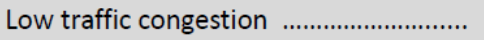 & O & O & O & O & 0 \\
\hline Walkability / accessibility ......................... & O & 0 & O & 0 & O \\
\hline Roads in good condition ................................ & 0 & 0 & 0 & 0 & 0 \\
\hline
\end{tabular}

\section{What ZIP code do you live in?}

4. How long have you lived in the community where you live now?
Less than 1 year
1 to 5 years
6 to 10 years
11 to 20 years
More than 20 years

\section{How satisfied are you with the quality-of-life in your community?}

\begin{tabular}{|c|c|c|c|c|}
\hline $\begin{array}{c}\text { Very } \\
\text { dissatisfied }\end{array}$ & Dissatisfied & $\begin{array}{l}\text { Neither } \\
\text { satisfied nor } \\
\text { dissatisfied }\end{array}$ & Satisfied & $\begin{array}{c}\text { Very } \\
\text { satisfied }\end{array}$ \\
\hline 0 & 0 & 0 & 0 & 0 \\
\hline
\end{tabular}


Think about where you live now...

\section{PAge 2 OF 8}

6. Rate the quality of each livability factor in your community right now: Check one per row.

\begin{tabular}{|c|c|c|c|c|c|}
\hline 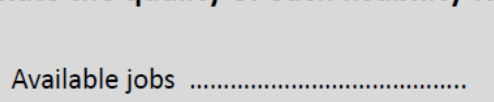 & $\begin{array}{c}\text { Very } \\
\text { poor } \\
\bigcirc\end{array}$ & $\begin{array}{c}\text { Poor } \\
0\end{array}$ & $\begin{array}{c}\text { Acceptable } \\
\bigcirc\end{array}$ & $\begin{array}{c}\text { Good } \\
0\end{array}$ & $\begin{array}{c}\text { Very } \\
\text { good } \\
0\end{array}$ \\
\hline Affordable transportation options ....... & $\mathrm{O}$ & 0 & 0 & 0 & 0 \\
\hline Cultural institutions & ○ & O & O & O & ○ \\
\hline Quality healthcare & 0 & $\mathrm{O}$ & O & 0 & O \\
\hline Affordable housing & O & $\mathrm{O}$ & O & O & $\mathrm{O}$ \\
\hline 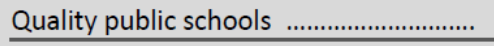 & 0 & 0 & 0 & 0 & 0 \\
\hline Overall cost of living & O & O & O & O & O \\
\hline Shopping and entertainment options ... & O & $\mathrm{O}$ & O & $\mathrm{O}$ & 0 \\
\hline Parks and recreation facilities ..................... & O & O & O & 0 & O \\
\hline 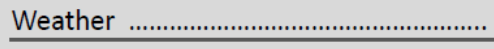 & 0 & 0 & 0 & 0 & 0 \\
\hline Clean environment & O & O & $\mathrm{O}$ & O & O \\
\hline Low crime & 0 & $\mathrm{O}$ & 0 & 0 & $\mathrm{O}$ \\
\hline Sense of community & O & $\mathrm{O}$ & 0 & O & ○ \\
\hline Traffic safety & 0 & $\mathrm{O}$ & O & 0 & O \\
\hline
\end{tabular}

7. Rate the quality of each aspect of transportation in your community right now: Check one per row.

\begin{tabular}{|c|c|c|c|c|c|}
\hline Public transit services & $\begin{array}{c}\text { Very } \\
\text { poor } \\
\end{array}$ & $\begin{array}{c}\text { Poor } \\
0\end{array}$ & Acceptable & $\begin{array}{c}\text { Good } \\
\bigcirc\end{array}$ & $\begin{array}{c}\text { Very } \\
\text { good } \\
\end{array}$ \\
\hline 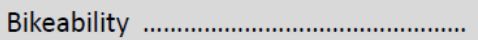 & 0 & 0 & $\mathrm{O}$ & O & O \\
\hline Low traffic congestion ................................. & $\mathrm{O}$ & $\mathrm{O}$ & $\mathrm{O}$ & $\mathrm{O}$ & $\mathrm{O}$ \\
\hline 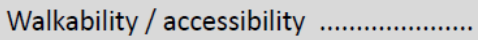 & 0 & $\mathrm{O}$ & $\mathrm{O}$ & $\mathrm{O}$ & O \\
\hline 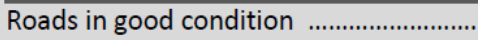 & 0 & 0 & $\mathrm{O}$ & 0 & 0 \\
\hline
\end{tabular}

People live on a wide variety of streets - from urban core downtowns streets to urban center streets to general urban streets to suburban streets to rural small town streets to natural/open-country streets.

8. Which of the following most closely describes the kind of street you live on?

Urban core street (downtown, high-rise/mid-rise housing units)

Urban center street (near downtown, multi-level housing units)

General urban street (single to multi-level buildings, townhomes/row houses/apartments/etc.)

Suburban street (mostly single-family houses or apartment buildings)

Rural street (small city/towns, typically single-family houses or small apartment buildings)

Open-country/Natural area (few houses, open-country mostly)

9. Which phrase best describes the way you define your community in terms of geographic size?

My community is a part of my local neighborhood.

My community is my whole local neighborhood.

My community is my city.

My community is my county.

My community is all of the region I live in.

Other: 


\section{Page 3 of 8}

10. How much do you agree or disagree with the following statement?

"I can easily travel to places I need to go in my community using my current travel options." Strongly disagree $\bigcirc$

\section{Disagree}

O
Neutral

O

\section{Strongly agree}

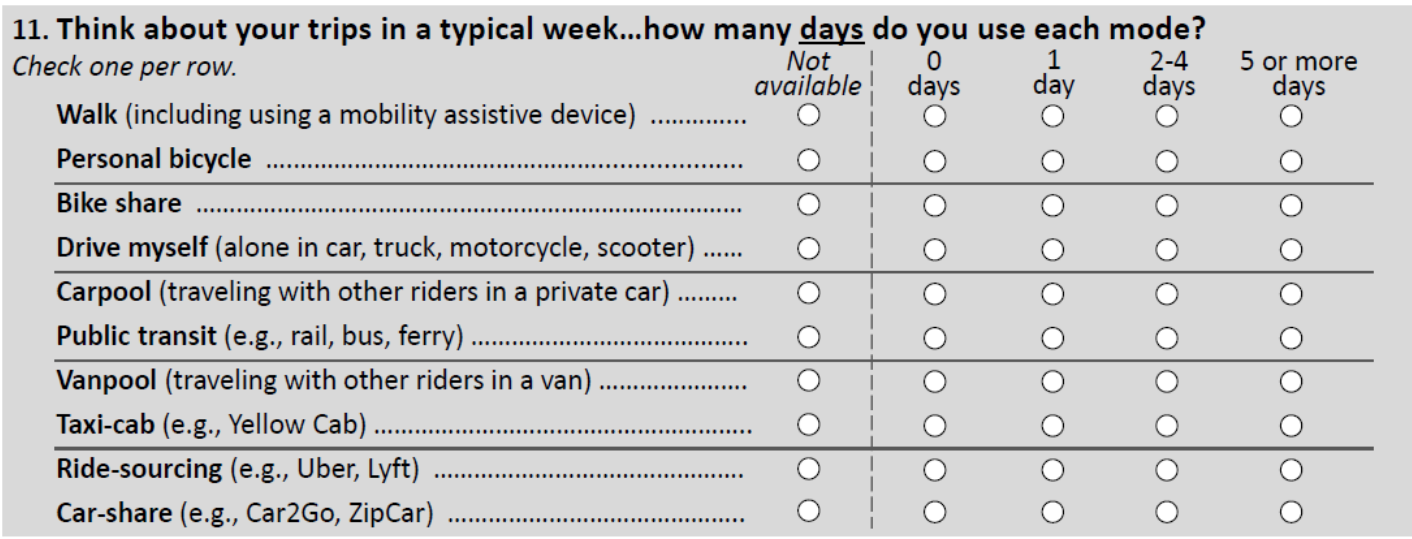

12. Is public transit currently available to residents of your community?

13a. Have you used public transit in your community?
$\bigcirc$ Yes O No $\begin{gathered}\text { 13b. If transit were available, how } \\ \text { likely are you to use public transit } \\ \text { for some of your trips? } \\ \text { 14. Do you know someone else who has used public } \\ \text { transit in your community? } \\ \text { Yes } \bigcirc \text { No }\end{gathered}$

\section{Which mode(s) of public transit are} available in your community? Check all that apply.

$\square$ Rail (e.g., light rail, commuter rail, subway, etc.)

$\square$ Local bus (e.g., fixed, flexible, deviated, etc.)

$\square$ Paratransit for people with disabilities

$\square$ Commuter bus (e.g., express, park-and-ride, etc.)

$\square$ Demand responsive transit (e.g., dial-a-ride, etc.)

$\square$ Intercity bus (e.g., Greyhound, Megabus, etc.)

$\square$ Ferry

$\square$ Other mode(s):
People use public transit to access a variety of services and amenities. We are interested in finding out if public transit can connect you with certain types of places.
16. If you chose to, could you ride public transit from near your residence to the following types of places? Check one per row.
Yes No Not

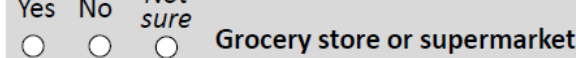
$\bigcirc \bigcirc$ Personal services (bank, hair/nail salon, laundromat)
$\bigcirc \bigcirc \bigcirc$ Other retail shopping (clothes, pharmacy, household goods)
$\bigcirc \bigcirc \bigcirc$ Recreation and Entertainment (parks, movies, museums, live theatre)
$\bigcirc \bigcirc$ Health care facility (doctor's office, urgent care, hospital)

Continue on Back... 


\section{Page 4 of 8}

17. If you are able, and chose to, could you walk from your residence to the following types of places? Yes No sure Check one per row.

$\bigcirc \bigcirc$ Grocery store or supermarket (fresh fruit, vegetables, bread, meat)

$\bigcirc \bigcirc$ Personal services (bank, hair/nail salon, laundromat)

$\bigcirc \bigcirc$ Other retail shopping (clothes, pharmacy, household goods)

$\bigcirc \bigcirc$ Recreation and Entertainment (parks, movies, museums, live theatre)

$\bigcirc$ Health care facility (doctor's office, urgent care, hospital)

18. How much do you agree or disagree with the following statement?

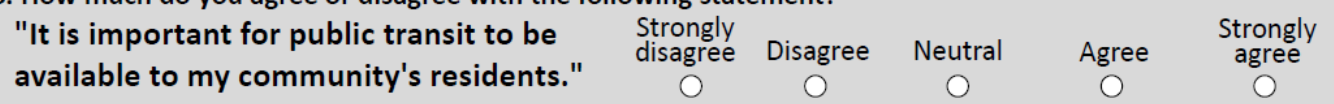

19. Why is it important to have public transit service in your community? Check all that apply.

$\square$ Because walk access to destinations is difficult in my community

$\square$ Because bike access to destinations is difficult in my community

$\square$ Transit is an option for seniors or people with disabilities

$\square$ Transit is an option for those who choose not to drive

$\square$ Transit is an option for saving on the cost of transportation

$\square$ Transit complements other travel modes, such as walking or biking

$\square$ Transit reduces energy consumption or protect air quality

$\square$ Transit eliminates the need to park or for destinations to provide parking

$\square$ Transit reduces traffic congestion

$\square$ I do not think it is important to have transit service.

20. How much do you agree with the following statements about funding transit? Check one per row.

\begin{tabular}{|c|c|c|c|c|c|}
\hline & $\begin{array}{l}\text { trongly } \\
\text { isagree }\end{array}$ & Disagree & Neutral & Agree & $\begin{array}{c}\text { Strongly } \\
\text { Agree }\end{array}$ \\
\hline I support using city funds for transit. & 0 & O & 0 & O & 0 \\
\hline I support using county (or equivalent) funds for transit. ........... & 0 & $\mathrm{O}$ & 0 & O & O \\
\hline I support using state funds for transit. & $\mathrm{O}$ & $\mathrm{O}$ & $\mathrm{O}$ & $\mathrm{O}$ & O \\
\hline I support using federal funds for transit. & 0 & 0 & 0 & 0 & 0 \\
\hline
\end{tabular}

21. Do you support more transit, less transit, or the same amount of transit in your community, given that public funds are needed to support part of the cost?

$\bigcirc$ Less public transit Same amount of public transit

More public transit

Most transit riders pay a fare to ride. The combined fares of all riders may or may not cover the entire cost of operating the service. In fact, most of the time transit services require some other sources of additional funds to pay for operations.

22. In general, how much of the total operating cost of transit should come from rider fares?

All $-100 \%$ (fares cover all costs)

Most - $>50 \%$ (fares cover more than half of costs)

Some $-<50 \%$ (fares cover less than half of costs)

None $-0 \%$ (no fare; other sources cover all costs)
23. Some transit riders pay a reduced fare. Who should be eligible for reduced fare? Check all that apply.

$\square$ Military veterans

$\square$ People with disabilities

$\square$ College/university students

$\square$ K-12 students

$\square$ Medicare or Medicaid cardholders

$\square$ Low-income individuals

$\square$ Other:

Continue on Page 5 


\section{Page 5 of 8}

We would like to understand how different situations would impact your choice to use or not use transit. We know from previous questions if you already use transit or not. So please answer the following question thinking about how each scenario may change your use of transit (or motivate you to begin using or stop using transit).

24. How would the following statements change your use of transit? $\begin{gathered}\text { ytop using } \\ \text { Stransit } \\ \text { Use transit } \\ \text { less often }\end{gathered}$
$\begin{gathered}\text { No one per row. } \\ \text { Change transit } \\ \text { more often }\end{gathered}$

Technology and Transportation in the Near Future

25. Assume you own a vehicle and smartphone...If you had to choose, which would you choose to give up permanently? $\quad$ Vehicle (car/truck/motorcycle/scooter)

Smartphone (e.g., iPhone/Android)

In the future, you may not need to own a vehicle to have access to a vehicle when needed. For example, you may be able to join a subscription-based car-sharing service or use another mobility service of some type.

26. Which of the following statements most likely describes your future vehicle ownership?

I do not own a vehicle now and I do not plan to get one in the future.

I I will no longer choose to own a vehicle in less than 1 year.

I I will no longer choose to own a vehicle in 1 to 10 years.

I I will no longer choose to own a vehicle in 11 to 20 years.

I I will no longer choose to own a vehicle at some point beyond 20 years.

I I will always choose to own my own vehicle.

Think about hourly or mileage based car-sharing services (e.g., Car2Go, CarShare, ZipCar) and assume they are available in your community now (if they are not already)...

\begin{tabular}{|c|c|c|c|c|c|}
\hline \multicolumn{6}{|c|}{ 27. How important is each factor in making car-sharing appealing and useful for you? } \\
\hline Check one per row. & $\begin{array}{l}\text { Not } \\
\text { important }\end{array}$ & $\begin{array}{l}\text { Slightly } \\
\text { important }\end{array}$ & $\begin{array}{l}\text { Moderately } \\
\text { important }\end{array}$ & Important & $\begin{array}{c}\text { Very } \\
\text { important }\end{array}$ \\
\hline Variety in type of vehicle (car, van, truck, scooter) ... & 0 & 0 & 0 & 0 & \\
\hline Wheelchair accessible vehicles .................................... & 0 & O & 0 & 0 & 0 \\
\hline Convenient vehicle location ......................................... & $\mathrm{O}$ & $\mathrm{O}$ & $\mathrm{O}$ & O & $\mathrm{O}$ \\
\hline Simple reservation process (internet, phone app) .... & 0 & O & 0 & 0 & 0 \\
\hline Low monthly or annual membership fee ......................... & $\mathrm{O}$ & $\mathrm{O}$ & $\mathrm{O}$ & $\mathrm{O}$ & $\mathrm{O}$ \\
\hline Low cost per mile/hour of service & $\mathrm{O}$ & O & 0 & O & $\mathrm{O}$ \\
\hline Low daily maximum rate (for multi-day rentals) ......... & $\mathrm{O}$ & $\mathrm{O}$ & $\mathrm{O}$ & $\mathrm{O}$ & $\mathrm{O}$ \\
\hline
\end{tabular}

Self-driving vehicles, called autonomous vehicles, will exist in the near future.

28. How comfortable are you with the idea of an autonomous vehicle picking up and dropping you off for a personal business appointment? uncomfortable Uncomfortable ○
Neutral

O
Comfortable

O
Very

comfortable

○
Continue ON BACK... 


\section{Page 6 of 8}

Please answer all questions. Responses are confidential.

29. All things considered, how satisfied are you with your life as a whole these days?

$\begin{array}{ccccccccccc}\begin{array}{c}\text { Completely } \\ \text { dissatisfied }\end{array} & \leftarrow \\ 0 & 1 & 2 & 3 & 4 & 5 & 6 & 7 & 8 & 9 & 10 \\ 0 & 0 & 0 & 0 & 0 & 0 & 0 & 0 & \bigcirc & 0 & 0\end{array}$

30. In general, how would you rate your overall
health? Poor
Fair
Good

31. Are you? $\quad$ Female

32. What is your age?
O 18 to 24 years
55 to 64 years
O 25 to 34 years
65 to 74 years
35 to 44 years
75 to 84 years
45 to 54 years
85 or more years

33. What is the highest degree or level of school you have completed?

Some grade school (K-12)

High school graduate (diploma or GED)

Some college

Associate's degree

Bachelor's degree

Master's, professional, or doctorate degree

34. Are you of Hispanic, Latino, or Spanish origin? OYes $O$ No

35. What is your race? Check all that apply.

$\square$ White, Caucasian

$\square$ Black or African American

$\square$ American Indian or Alaska Native

$\square$ Native Hawaiian or Other Pacific Islander

$\square$ Asian

$\square$ Some Other Race:

36. Including yourself, how many people live in your household? $11 \quad 2 \quad 3 \quad 4 \quad 5 \quad 6$ or more $0 \bigcirc \bigcirc \bigcirc \bigcirc \bigcirc$

37. How many people in your household, including yourself and children, cannot drive?
$\bigcirc 0$
$\bigcirc 1$
$\bigcirc 2$
3 or more

38. Do you have a driver's license?
$\bigcirc$ Yes
O No

Continue top of next column
39. How many working vehicles (cars, trucks, and motorcycles) are available in your household? $\quad 0 \quad 1 \quad 23$ or more

40. Which of the following best describes your current employment status? Check all that apply.

$\square$ Employed full-time

$\square$ Employed part-time

$\square$ Student

$\square$ Homemaker

$\square$ Retired

$\square$ Unable to work due to a disability

$\square$ Not employed, looking for work

$\square$ Other:

41. What is the combined annual income for all people living in your household?

Less than $\$ 15,000$

$\$ 15,000$ to $\$ 24,999$

$\$ 25,000$ to $\$ 34,999$

$\$ 35,000$ to $\$ 49,999$

O $\$ 50,000$ to $\$ 74,999$

o $\$ 75,000$ to $\$ 99,999$

O $\$ 100,000$ to $\$ 249,999$

O $\$ 250,000$ or more

42. Have you served on active duty in the U.S. Armed Forces, Reserves, or National Guard?

O No $\begin{array}{r}\text { Yes, previously } \\ \text { O Yes, currently }\end{array}\left(\begin{array}{l}\text { Thank you for } \\ \text { your service. }\end{array}\right)$

43. Are you currently covered by either of the following programs? Check one per row.

Yes No

$\bigcirc \bigcirc$ Medicare (age 65+ or Social Security Disability)

$\bigcirc \bigcirc$ Medicaid (low income or people with disabilities)

44. Do you have serious difficulty walking or climbing stairs? $\bigcirc$ Yes No 45. Do you use a wheelchair or other mobility assistive device to travel outside your residence?

$\bigcirc$ Yes

No 
Page 7 Of 8

46. Please share any final comments you have regarding community livability or public transit:

Returning a completed survey means you are eligible to receive one $\$ 3.00$ online gift card code.

Please indicate how you prefer to receive your gift card code by providing an SMS text capable mobile phone number or email address.

SMS text capable mobile phone number: $(x X X) x x x-x x x x$

Email address: name@online.com

Please write clearly and double-check your spelling. We will not re-send undeliverable or returned messages. You will receive your code in the next four weeks.

\section{Are you a current or former rider of public transit?}

If NO... you are finished. Return all pages using the provided envelope.

If YES... please take 3 more minutes to answer a few questions about your use of transit...

\section{A Few Questions for Transit Riders}

47. How often do you ride public transit?
6 or 7 days per week
1 or 2 days per month
4 or 5 days per week
Less than once per month
2 or 3 days per week
I no longer ride transit.
1 day per week

48. How much do you agree or disagree with the following statement?

"Public transit is very important to my quality-of-life."

Strongly disagree

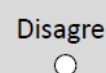

Neutral

Agree $\quad \begin{gathered}\text { Strongly } \\ \text { agree }\end{gathered}$

49. How likely is it that you would recommend the public transit service you ride to a friend or colleague? Not at all likely

$\begin{array}{ll}0 & 1 \\ 0 & 0\end{array}$

50. Why did you start riding public transit? Check all that apply.

$\square$ I wanted to be more physically active.

$\square$ I did not want to drive in poor weather (rainy, snowy).

$\square$ I enjoyed the social interaction of riding transit.

$\square$ I decided to use transit for convenience.

$\square$ I no longer had access to a vehicle.

$\square$ I decided to use transit to save money.

I could no longer drive or had difficulties driving.

$\square$ I decided to use transit to reduce my energy consumption or protect air quality.

$\square$ I could not get a ride from others or did not want to.

$\square$ I have a disability that limits my ability to travel other ways.

$\square$ I wanted to avoid congestion.

$\square$ I wanted to make better use of my time while traveling.

$\square$ Other reason(s):

ContinUe ON BACK... 


\section{Page 8 of 8}

About Your Most Recent Trip on Transit

Please answer the following questions about the most recent trip you took on transit.

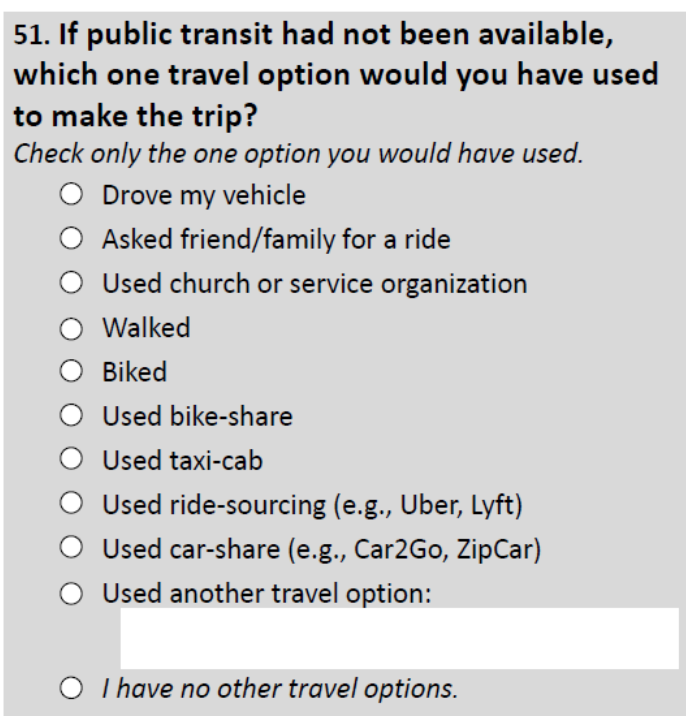

52. When was your most recent trip on transit?

Today

Another day this week

Last week

2 to 4 weeks ago

More than 4 weeks ago

Not sure

53. Which mode(s) of public transit did you use on the trip? Check all that apply.

Rail (e.g., light rail, commuter rail, subway, etc.)

$\square$ Local bus (e.g., fixed, flexible, deviated, etc.)

Paratransit for people with disabilities

Commuter bus (e.g., express, park-and-ride, etc.)

Demand responsive transit (e.g., dial-a-ride, etc.)

Intercity bus (e.g., Greyhound, Megabus, etc.)

Vanpool

Ferry

Other mode(s):

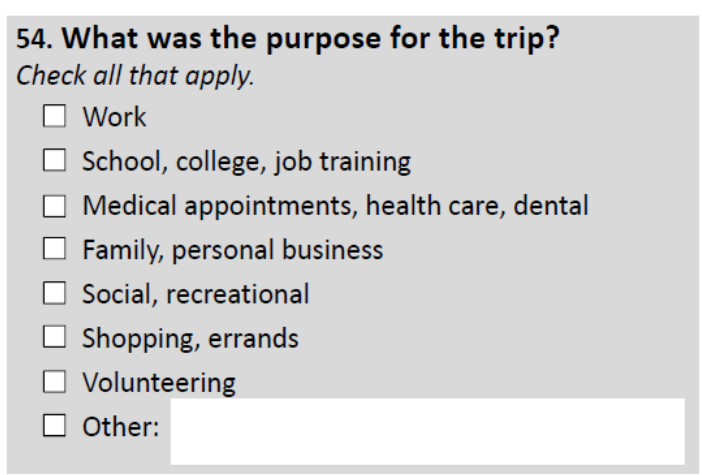

55. How much do you agree or disagree with the following statements? Check one per row.

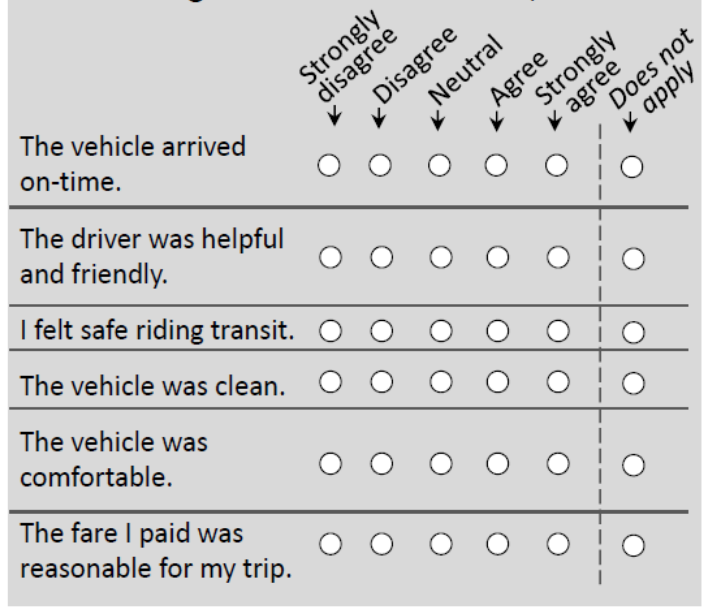

\section{FINISHED!}

Return all PAges in the PROVIDEd enVelope. 
Mailer Survey Instrument: Spanish

\section{PÁGINA 1 de 8}

\section{Empiece aquí}

Piense en los miles de comunidades en los Estados Unidos...

1. En su opinión, ¿qué tan importante es cada uno de estos factores para la habitabilidad de la comunidad? Marque uno por línea. Noes Ligeramente Moderadamente Muy

importante importante importante Importante importante

Trabajo disponible.

$\mathrm{O}$

Alternativas asequibles (económicamente accesibles)...

Instituciones culturales

Servicios médicos de calidad.

Vivienda asequible

Escuelas públicas de calidad

Costo de la vida en general

Alternativas de compras y ocio

Parques e instalaciones recreativas

Clima

Medio ambiente limpio

Baja criminalidad

Sensación de comunidad

Seguridad vial

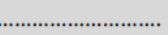

0

0

$\mathrm{O} \quad 0$

0

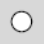

0

O

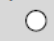

$\mathrm{O}$

$0 \quad 0 \quad 0$

0

$0 \quad 0 \quad 0$

$0 \quad 0$

O

$\mathrm{O}$

$\circ$

$\begin{array}{llll}0 & 0 & 0 & 0\end{array}$

$\begin{array}{lllll}0 & 0 & 0 & 0 & 0 \\ 0 & 0 & 0 & 0 & 0 \\ 0 & 0 & 0 & 0 & 0 \\ 0 & 0 & 0 & 0 & 0 \\ 0 & 0 & 0 & 0 & 0 \\ 0 & 0 & 0 & 0 & 0 \\ 0 & 0 & 0 & 0 & 0\end{array}$

2. ¿Qué tan importante es cada uno de estos aspectos del transporte para la habitabilidad de la comunidad? Marque uno por línea.

$$
\begin{gathered}
\text { No es } \\
\text { importante }
\end{gathered}
$$

Ligeramente

importante Moderadamente

importante

Muy

Servicios de transporte público.......................

Vialidad en bicicleta ...........................................

Poca congestión de tráfico................................

Vialidad peatonal / accesibilidad

$\mathrm{O}$

O

Importante

importante

Carreteras en buenas condiciones...................

$0 \quad 0$

$\mathrm{O}$

$\mathrm{O}$

$\mathrm{O}$

$\mathrm{O} 0$

O

$\mathrm{O}$

$\bigcirc$

\begin{tabular}{ll}
0 & 0 \\
0 & 0 \\
\hline & 0
\end{tabular}

\section{3. ¿En qué código postal vive?}

\section{4. ¿Cuánto tiempo lleva viviendo en esta comunidad?}
Menos de 1 año
De 1 a 5 años
De 6 a 10 años
De 11 a 20 años
Más de 20 años

5. ¿Qué tan satisfecho está con la calidad de vida en su comunidad?
Muy
insatisfecho
Insatisfecho
Ni satisfecho ni
insatisfecho
Satisfecho
Muy
satisfech
O
O
$\bigcirc$
O
O

Continuar al ReVerso 


\section{Página 2 de 8}

Piense en el lugar donde vive actualmente...

6. Califique la calidad de cada factor de habitabilidad en su comunidad actualmente:

\begin{tabular}{|c|c|c|c|c|}
\hline Marque uno por línea. & Mala & Aceptable & Buena & Muy buena \\
\hline Trabajo disponible & O & O & O & O \\
\hline Alternativas asequibles (económicamente accesibles) .. & O & O & O & O \\
\hline Instituciones culturales & $\mathrm{O}$ & $\mathrm{O}$ & O & $\mathrm{O}$ \\
\hline Servicios médicos de calidad ........................................... & $\mathrm{O}$ & 0 & O & O \\
\hline Vivienda asequible & $\mathrm{O}$ & O & O & O \\
\hline Escuelas públicas de calidad & O & O & O & O \\
\hline Costo de la vida en general & $\mathrm{O}$ & $\mathrm{O}$ & $\mathrm{O}$ & $\mathrm{O}$ \\
\hline Alternativas de compras y ocio ........................................ & O & ○ & O & O \\
\hline Parques e instalaciones recreativas ................................... & $\mathrm{O}$ & $\mathrm{O}$ & $\mathrm{O}$ & $\mathrm{O}$ \\
\hline 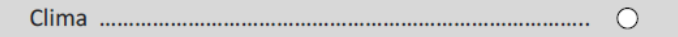 & O & O & 0 & O \\
\hline Medio ambiente limpio ......................................................... & $\mathrm{O}$ & O & 0 & $\mathrm{O}$ \\
\hline Baja criminalidad & O & O & O & O \\
\hline 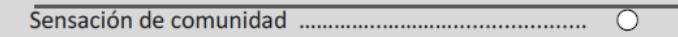 & 0 & $\mathrm{O}$ & $\mathrm{O}$ & $\mathrm{O}$ \\
\hline Seguridad vial & O & 0 & 0 & O \\
\hline
\end{tabular}

7. Califique la calidad de cada aspecto de transporte en su comunidad actualmente:

\begin{tabular}{|c|c|c|c|c|c|}
\hline Marque uno por línea. & Muy mala & Mala & Aceptable & Buena & Muy buena \\
\hline Servicios de transporte público ......................... & $\bigcirc$ & $\bigcirc$ & 0 & 0 & $\mathrm{O}$ \\
\hline 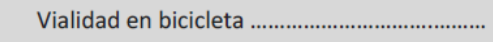 & $\bigcirc$ & $\bigcirc$ & $\bigcirc$ & $\mathrm{O}$ & $\bigcirc$ \\
\hline Poca congestión de tráfico ............................... & O & O & O & O & $\mathrm{O}$ \\
\hline Vialidad peatonal / accesibilidad .................. & O & O & O & O & 0 \\
\hline Carreteras en buenas condiciones ................. & O & O & 0 & $\mathrm{O}$ & $\mathrm{O}$ \\
\hline
\end{tabular}

Las personas viven en una variedad de vías-desde calles principales en el centro urbano, calles céntricas urbanas, calles urbanas generales, calles suburbanas, calles rurales en poblaciones pequeñas, a caminos en campo abierto o zonas naturales.

8. ¿Cuál de las siguientes describe mejor el tipo de vía en la que usted vive?

Calle principal en el centro urbano (centro, viviendas en edificios altos o de mediana altura)

Calle céntrica urbana (cerca del centro, viviendas en edificios de múltiples niveles)

Calle urbana general (edificios de un solo nivel o de niveles múltiples, adosados/pareados/apartamentos/ etc.)

Calle suburbana (principalmente viviendas unifamiliares o edificios de apartamentos)

Calle rural (población pequeña/pueblo, típicamente casas unifamiliares o edificios pequeños de apartamentos)

Campo abierto/zona natural (pocas casas, principalmente campo abierto)

9. ¿Qué frase describe mejor la manera cómo define usted su comunidad en cuanto a su tamaño geográfico?

Mi comunidad forma parte de mi vecindario local.

Mi comunidad es mi condado.

Mi comunidad es mi vecindario local en su totalidad.

Mi comunidad es toda la región en la que vivo.

Mi comunidad es mi ciudad.

Otro: 


\section{PÁgINA 3 de 8}

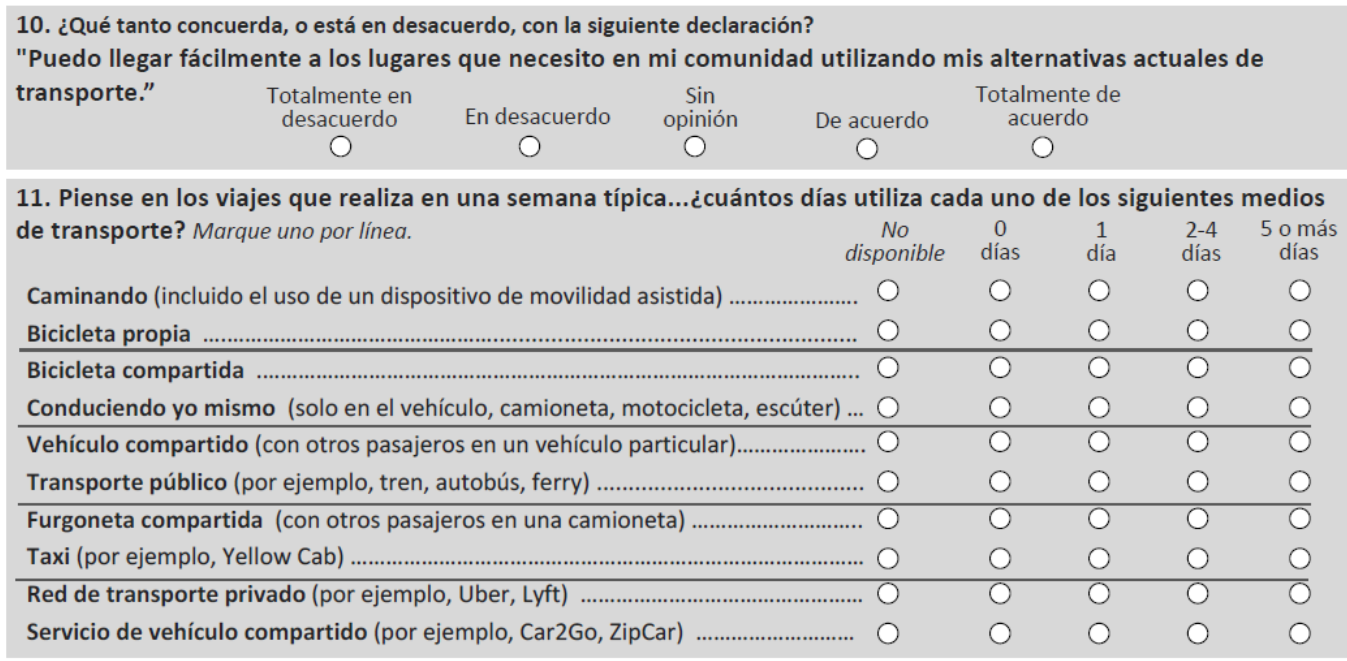

12. ¿Actualmente hay transporte público disponible para los residentes de su comunidad?

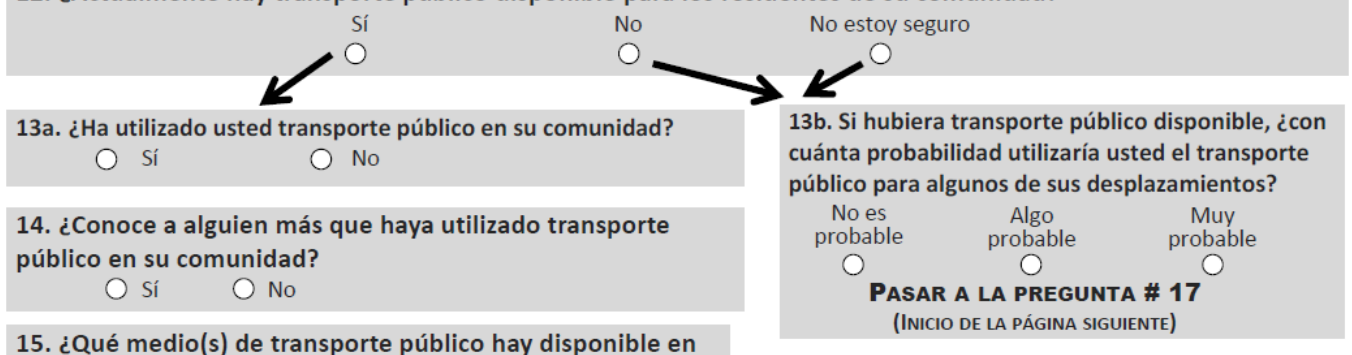

su comunidad? Marque todos los que correspondan.

$\square$ Tren (por ejemplo, tren ligero, tren de cercanías, metro, etc.)

$\square$ Autobús local (por ejemplo, fijo, flexible, desviado, etc.)

$\square$ Paratránsito para personas con discapacidades

$\square$ Autobús de cercanías (por ejemplo, directo, estacionar y utilizar transporte público [park-and-ride], etc.)

$\square$ Transporte compartido según demanda (por ejemplo, dial-aride, etc.)

$\square$ Autobús interurbano (por ejemplo, Greyhound, Megabus)

$\square$ Furgoneta compartida

$\square$ Ferry

$\square$ Otro(s) Modo(s):

Las personas utilizan el transporte público para acceder a una variedad de servicios. Nos interesa saber si el transporte público le acerca a usted a ciertos tipos de lugares.
16. Si usted lo deseara, ¿jpodría ir en transporte público desde cerca de su vivienda a los siguientes lugares? Marque uno por línea. Sí No $\begin{gathered}\text { No estoy } \\ \text { seguro }\end{gathered}$
$\bigcirc \bigcirc \begin{aligned} & \text { Tiendas de alimentación o } \\ & \text { supermercado (fruta fresca, }\end{aligned}$ verduras, pan, carne)
$\bigcirc \bigcirc$ Servicios personales (banco, salón de belleza/uñas, lavandería)
$\bigcirc \quad 0$ Otras tiendas minoristas (prendas de vestir, farmacia, artículos del hogar)
$\bigcirc \bigcirc$ Recreación y ocio (parques, cines, museos, teatros)
$\bigcirc \bigcirc$ Instalaciones médicas (consulta del médico, urgencias, hospital)

Continuar al ReVerso 


\section{PÁGINA 4 dE 8}

17. Si pudiera y quisiera, ¿jpodría caminar desde cerca de su vivienda a los siguientes lugares? Marque uno por línea. Sí No No estoy seguro

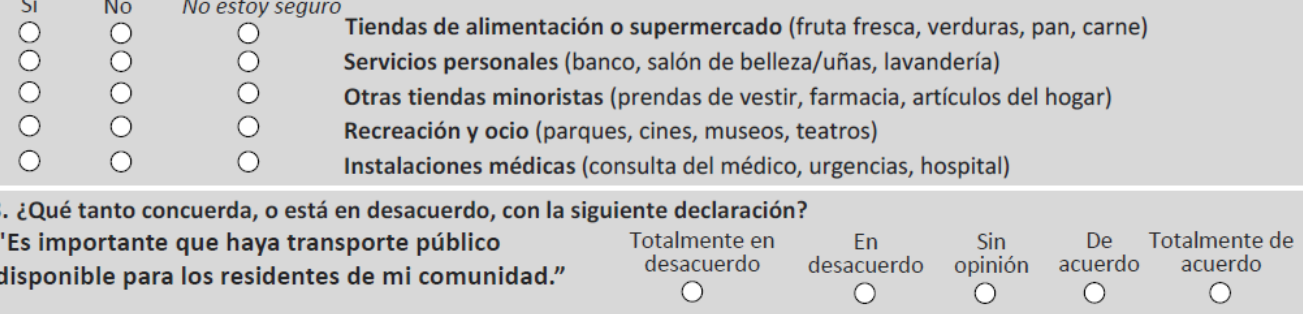

19. ¿Por qué es importante que haya servicios de transporte público en su comunidad? Marque todos los que correspondan.

$\square$ Porque el acceso a pie a ciertos lugares es difícil en mi comunidad

$\square$ Porque el acceso en bicicleta a ciertos lugares es difícil en mi comunidad

$\square$ El transporte público es una alternativa para personas mayores y personas discapacitadas

$\square$ El transporte público es una alternativa para quienes prefieren no conducir

$\square$ El transporte público es una alternativa para ahorrar en el costo del transporte

$\square$ El transporte público complementa otros modos de desplazamiento, tales como caminar o ir en bicicleta

$\square$ El transporte público reduce el consumo de energía y protege la calidad del aire

$\square$ El transporte público elimina la necesidad de estacionarse o la necesidad de proporcionar estacionamiento en el lugar de destino

$\square$ El transporte público reduce la congestión del tránsito

$\square$ No creo que sea importante tener servicios de transporte público.

20. ¿Qué tanto concuerda, o está en desacuerdo, con las siguientes declaraciones sobre la financiación del

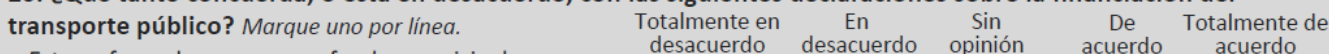

Estoy a favor de que se usen fondos municipales para

servicios de transporte público.

Estoy a favor de que se usen fondos del condado

(o equivalente) para servicios de transporte público.

Estoy a favor de que se usen fondos estatales

para servicios de transporte público.

Estoy a favor de que se usen fondos federales

para servicios de transporte público.

21. ¿Está a favor de que haya más transporte público, menos, o igual en su comunidad, dado que son necesarios fondos públicos para financiar parte del costo?

Menos transporte público $\quad$ La misma cantidad de transporte público

Más transporte público

La mayoría de los pasajeros de transporte público pagan una tarifa de transporte. Las tarifas combinadas de todos los pasajeros pueden

cubrir o no la totalidad del costo de operaciones del servicio. De hecho, en la mayoría de los casos los servicios de transporte público requieren fuentes adicionales de financiación para pagar sus operaciones.

22. En general, ¿qué cantidad del costo total de operaciones del transporte público debe proceder de las tarifas de los pasajeros?

Todo- $100 \%$ (las tarifas cubren todos los costos)

La mayor parte - $>50 \%$ (las tarifas cubren más de la mitad de los costos)

Algo $-<50 \%$ (las tarifas cubren menos de la mitad de los costos)

Nada $-0 \%$ (otras fuentes, no las tarifas, cubren todos los costos)

23. Algunos pasajeros de transporte público pagan una tarifa reducida. ¿Quién debería ser elegible para pagar la tarifa reducida? Marque todos los que correspondan.

$\square \quad$ Veteranos militares

$\square$ Personas con discapacidades

$\square$ Estudiantes universitarios/colegio universitario

$\square \quad$ Estudiantes de K-12

$\square \quad$ Titulares de Medicare o Medicaid

$\square$ Personas de bajos ingresos

$\square$ Otro:

CONTINUAR EN LA PÁGINA 5 


\section{Página 5 de 8}

Nos gustaría comprender de qué modo diferentes situaciones pueden afectar su decisión para usar o no el transporte público. Por las preguntas anteriores ya sabemos si usted utiliza o no el transporte público. Le agradecemos responda a la siguiente pregunta pensando de qué modo cada una de las situaciones podría cambiar su uso del transporte público (o motivarle a comenzar a usarlo, o dejar de usarlo).

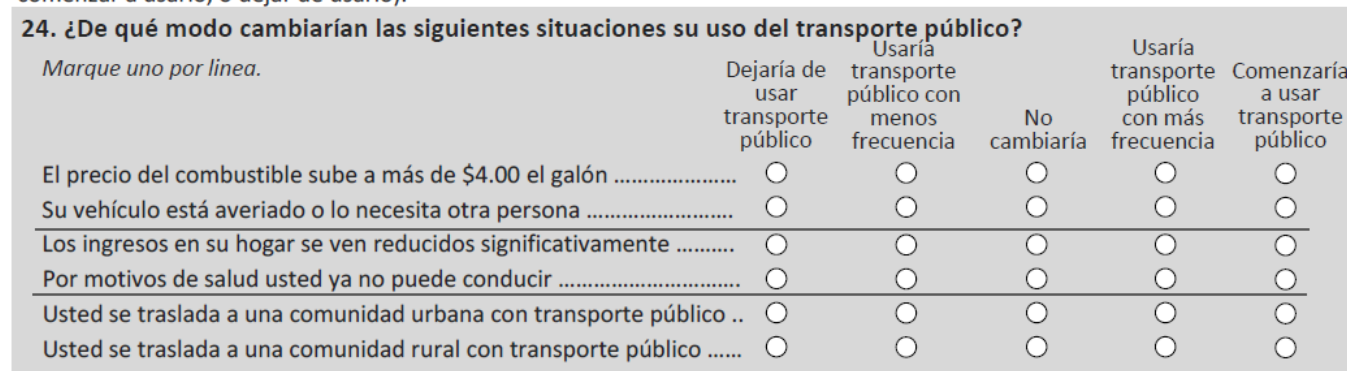

Tecnología y transporte en un futuro próximo

25. Suponga que usted tiene un vehículo y un smartphone...Si pudiera escoger, ca cuál de los dos renunciaría de forma permanente? $\quad$ Vehículo (auto/camioneta/motocicleta/escúter)

Smartphone (por ejemplo, iPhone/Androide)

En el futuro, es posible que no necesite ser propietario de un vehículo para tener acceso a uno cuando lo necesite. Por ejemplo, puede suscribirse a un servicio para compartir vehículos o utilizar otro servicio de movilidad de algún tipo.

26. ¿Cuál de las siguientes declaraciones describe mejor su situación como propietario de un vehículo en el

futuro? ONo tengo un vehículo ahora y no tengo intención de comprar ninguno en el futuro.

Elegiré no ser dueño de un vehículo en menos de 1 año.

Elegiré no ser dueño de un vehículo en 1 a 10 años.

Elegiré no ser dueño de un vehículo en 11 a 20 años.

Elegiré no ser dueño de un vehículo en 11 a 20 años.

O Elegiré no ser dueño de un vehículo pasados 20 años.

Siempre elegiré ser dueño de mi propio vehículo.

Piense en servicios de vehículo compartido mediante suscripción por hora o millas (por ejemplo, Car2Go, CarShare, ZipCar) y suponga que estuvieran disponibles en su comunidad en la actualidad (si acaso no lo estuvieran ya)...

27. ¿Qué tan importante es cada uno de los factores siguientes para que el servicio de vehículo compartido sea atractivo y útil para usted? Marque uno por línea. No es Ligeramente Moderadamente Muy importante importante importante Importante importante Tipo de vehículo (auto, furgoneta, camioneta, escúter) ................. Vehículos accesibles para sillas de ruedas Ubicación conveniente del vehículo Suscripción mensual o anual económica ............................................

Bajo costo por milla/hora de servicio .................................................. Tarifa máxima por día económica (para alquileres de varios días) ..

\section{O}

O - -

$\begin{array}{lll}0 & 0 & 0 \\ 0 & 0 & 0 \\ 0 & 0 & 0 \\ 0 & 0 & 0 \\ 0 & 0 & 0 \\ 0 & 0 & 0 \\ 0 & 0 & 0\end{array}$

En un futuro próximo existirán los vehículos autónomos.

28. ¿Qué tan cómodo se siente usted con la idea de que un vehículo autónomo le recoja y le deje en un lugar para una cita personal o de negocios?

Muy incómodo

Incómodo

Sin opinión

Cómodo

Muy cómodo

O

O

O

$\mathrm{O}$

$\mathrm{O}$

Continuar al ReVerso 


\section{Página 6 de 8}

Le agradecemos responda a todas las preguntas. Las respuestas son confidenciales.

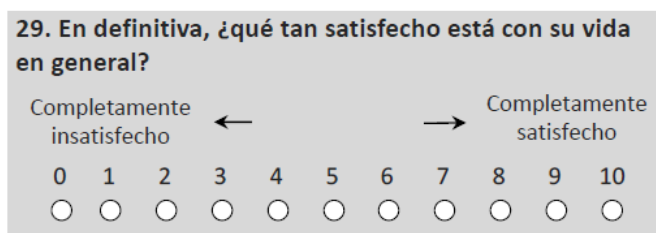

30. En general, ¿cómo calificaría su salud?

$$
\text { Mala } \bigcirc \text { Regular } \bigcirc \text { Buena }
$$

31. ¿Es usted... OMujer O Hombre Sin listar:

\section{2. ¿Qué edad tiene?}
Entre 18 y 24 años $\bigcirc$ Entre 55 y 64 años
Entre 25 y 34 años $\bigcirc$ Entre 65 y 74 años
Entre 35 y 44 años $\bigcirc$ Entre 75 y 84 años
Entre 45 y 54 años 85 o más años

33. ¿Cuál es su nivel o grado de estudios más elevado alcanzado?

Algún grado de preparatoria (K-12)

Graduado de la preparatoria (diploma o GED)

Algún curso universitario

Título asociado

Licenciatura universitaria

Título de maestría, profesional o doctorado

34. ¿Es usted de origen hispano, latino o español?

$$
\text { OSí }
$$$$
\text { No }
$$

35. ¿Cuál es su raza? Marque todos los que correspondan.

$\square$ Blanco, Caucásico

$\square$ Negro o afroamericano

$\square$ Indio americano o autóctono de Alaska

$\square$ Autóctono de Hawaii o de otras Islas del Pacífico

Asiático

Otra raza:

36. ¿Cuántas personas viven en su hogar, incluido usted? $\quad \begin{array}{llllll} & 2 & 3 & 4 & 5 & 6\end{array}$ más

$$
0 \bigcirc \bigcirc \bigcirc \bigcirc
$$

37. ¿Cuántas personas en su hogar tienen de 0 a 15 años de edad (no conducen)? $0 \begin{array}{llll}0 & 1 & 2 & 3\end{array}$ omás

$$
0000
$$

38. ¿Tiene usted licencia de conducir?

$$
\text { OSí } O \text { No }
$$

39. ¿Cuántos vehículos en funcionamiento (autos, camionetas y motocicletas) hay disponibles en su hogar?

$$
\begin{array}{llll}
0 & 1 & 2 & 3 \text { o más } \\
\bigcirc & \bigcirc & \bigcirc & \bigcirc
\end{array}
$$

40. ¿Cuál de los siguientes enunciados describe mejor su situación actual de empleo? Marque todos los que correspondan.

$\square$ Empleado a tiempo completo

$\square$ Empleado a tiempo parcial

$\square$ Estudiante

$\square$ Ama de casa

$\square$ Retirado

$\square$ No puedo trabajar debido a una discapacidad

$\square$ Sin empleo, busco trabajo

$\square$ Otro:

41. ¿Cuáles son los ingresos anuales combinados de todas las personas que viven en su hogar?

Menos de $\$ 15,000$

De $\$ 15,000$ a $\$ 24,999$

De $\$ 25,000$ a $\$ 34,999$

De $\$ 35,000$ a $\$ 49,999$

$\mathrm{O}$ De $\$ 50,000$ a $\$ 74,999$

De $\$ 75,000$ a $\$ 99,999$

De $\$ 100,000$ a $\$ 249,999$

O $\$ 250,000$ o más

42. ¿Ha servido en activo en el ejército, en las fuerzas armadas, en la reserva o en la guardia nacional de los Estados Unidos? $\mathrm{O}$ No Sí, anteriormente

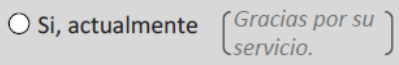

43. ¿Está cubierto actualmente por alguno de los siguientes programas? Marque uno por línea.

Sí No

$\bigcirc \bigcirc$ Medicare (mayores de 65 años de edad o seguridad social para discapacitados)

O Medicaid (personas de bajos ingresos o con discapacidades)

44. ¿Tiene mucha dificultad para caminar o subir escaleras?

$$
\text { O Sí }
$$

No

45. ¿Utiliza silla de ruedas u otro dispositivo de movilidad asistida para desplazarse fuera de su hogar? ○ sí No

Continuar en LA PÁGINA $7 \rightarrow$ 


\section{PÁGINA 7 de 8}

46. Le agradecemos incluya cualquier comentario que tenga acerca de la habitabilidad de la comunidad o transporte público.

Cuando nos devuelva la encuesta completada, será elegible para recibir una tarjeta regalo codificada de por valor de $\$ 3.00$.

Díganos cómo prefiere recibir su tarjeta regalo codificada indicando un número de teléfono móvil donde pueda recibir mensajes de texto SMS, o una dirección de correo electrónico:

Número de teléfono móvil para recibir mensajes de texto SMS:

$$
\begin{aligned}
& (x x x) x x x-x x x x \\
& \text { Dirección de correo electrónico: }
\end{aligned}
$$

$$
\text { nombre@online.com }
$$

Escriba claramente y verifique la ortografía. No enviaremos de nuevo mensajes no entregados o mensajes devueltos. Recibirá su código en las próximas cuatro semanas.

\section{¿Es usted pasajero antiguo o actual de transporte público?}

NO... ya ha terminado. Devuelva todas las páginas utilizando el sobre proporcionado.

Sí... por favor tome 3 minutos más para responder a algunas preguntas sobre su uso del transporte..

\section{Algunas preguntas para los pasajeros de transporte público}

47. ¿Con qué frecuencia usa transporte público?
6 o 7 días a la semana
1 o 2 días al mes
4 o 5 días a la semana
Menos de una vez al mes
2 o 3 días a la semana
Ya no uso transporte público.
1 día a la semana

48. ¿Qué tanto concuerda, o está en desacuerdo, con la siguiente declaración?

"El transporte público es muy importante para mi calidad de vida."
Totalmente en
En
Sin
De
Totalmente de
desacuer
acuerdo

$$
\text { O }
$$

O

O

49. ¿Qué tan probable es que usted recomiende el servicio de transporte público que usa a un amigo o colega? Nada probable

Sumamente probable

50. ¿Por qué comenzó a usar transporte público? Marque todos los que correspondan.

$\square$ Quería estar más activo físicament

$\square$ No quería conducir en mal tiempo (lluvioso, con nieve).

$\square$ Me gustaba el intercambio social que resultaba de usar transporte público.

$\square$ Decidí usar transporte público por comodidad.

$\square$ Ya no tenía acceso a un vehículo.

$\square$ Decidí usar transporte público para ahorrar dinero.

$\square$ Decidí usar transporte público para reducir mi consumo de energía y proteger la calidad del aire.

$\square$ Ya no podía conducir o tenía dificultades para conducir.

$\square$ No pude, o no quise, ir como pasajero en otro vehículo.

$\square$ Tengo una discapacidad que me limita para viajar de otro modo. $\square$ Quería evitar la congestión de tráfico.

$\square$ Quería usar mejor mi tiempo durante mis desplazamientos.

$\square$ Otro(s) motivo(s): 


\section{PÁgina 8 de 8}

Su viaje más reciente en transporte público

Responda a las siguientes preguntas acerca de su desplazamiento más reciente en transporte público.

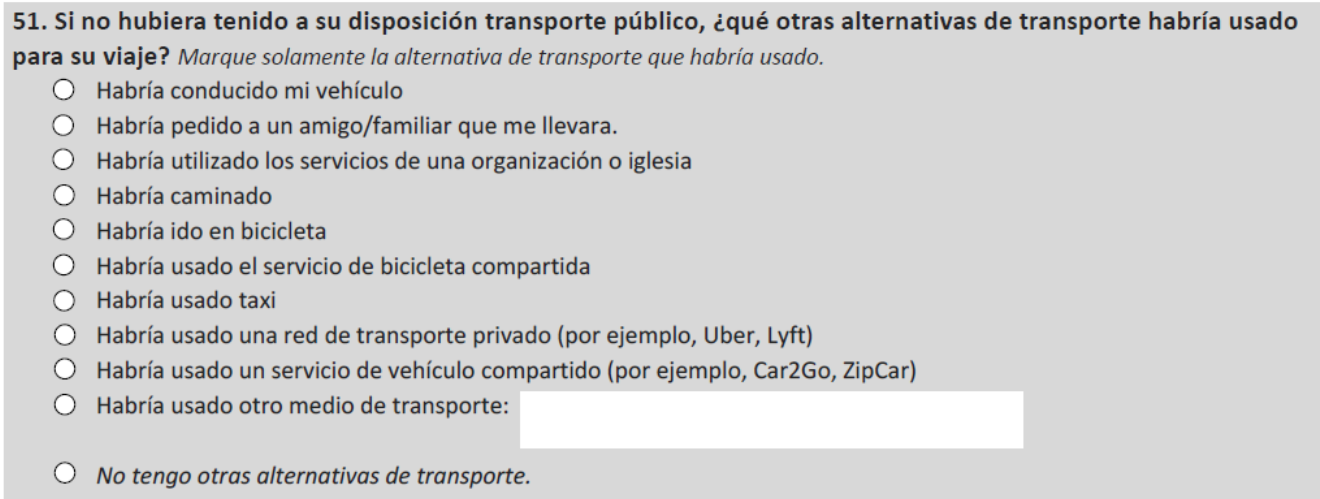

52. ¿Cuándo hizo su desplazamiento más reciente en transporte público?

Hoy

Otro día esta semana

La semana pasada

Hace 2 a 4 semanas

Hace más de 4 semanas

No estoy seguro

53. Qué modo(s) de transporte público usó en su viaje? Marque todos los que correspondan.

$\square$ Tren (por ejemplo, tren ligero, tren de cercanías, metro, etc.)

$\square$ Autobús local (por ejemplo, fijo, flexible, desviado, etc.)

$\square$ Paratránsito para personas con discapacidades

$\square$ Autobús de cercanías (por ejemplo, directo, estacionar y utilizar transporte público [park-andride], etc.)

$\square$ Transporte compartido según demanda (por ejemplo, dial-a-ride, etc.)

$\square$ Autobús interurbano (por ejemplo, Greyhound, Megabus, etc.)

$\square$ Furgoneta compartida

$\square$ Ferry

Otro(s) modo(s):
54. ¿Cuál fue el propósito de su viaje? Marque todos los que correspondan.

$\square$ Trabajo

$\square$ Escuela, universidad, capacitación laboral

$\square$ Citas médicas, atención médica, servicios dentales

$\square$ Familia, cuestiones personales

$\square$ Social, recreativo

$\square$ Compras, mandados

$\square$ Voluntariado

$\square$ Otro:

55. ¿Qué tanto concuerda, o está en desacuerdo, con las siguientes declaraciones?

Marque uno por línea.

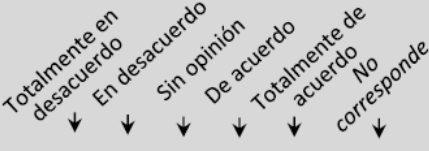

El vehículo llegó

puntualmente.

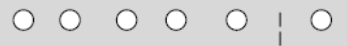

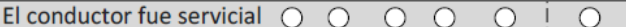

y amable.

\begin{tabular}{llllll:l}
\hline Me sentí seguro como & 0 & 0 & $\bigcirc$ & 0 & 0 & 0
\end{tabular}

\begin{tabular}{lllllll} 
pasajero. & & & & & \\
\hline El vehículo estaba limpio. & 0 & 0 & 0 & 0 & $\bigcirc$ & 0
\end{tabular}

\begin{tabular}{llllll:l}
\hline El vehículo era cómodo. & 0 & 0 & 0 & 0 & 0 & 0
\end{tabular}

La tarifa que pagué era $\bigcirc \bigcirc 000$ razonable para mi

desplazamiento.

¿YA HA TERMINADO!

DEVUUELVA TODAS LAS PÁGINAS EN EL SOBRE PROPORCIONADO. 